\title{
DoE/NV/10461-T5/
}

\author{
STATE OF NEVADA \\ AGENCY FOR NUCLEAR PRO,JECTS \\ NUCLEAR WASTE PROJECT
}

NWPO-TR-022-94

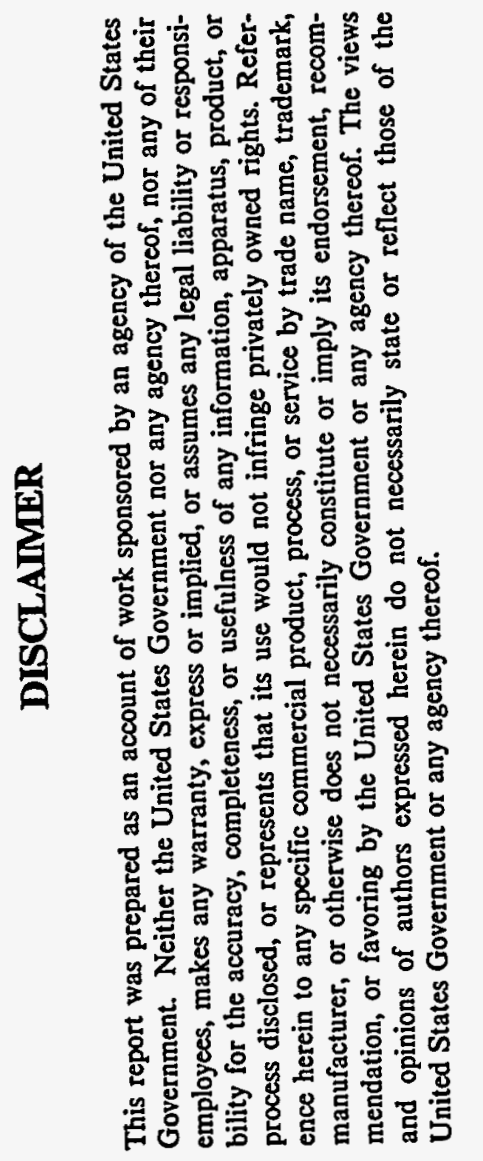

\section{PALEOHYDROLOGIC INVESTIGATIONS IN THE VICINITY OF YUCCA MOUNTAIN: \\ LATE QUATERNARY PALEOBOTANICAL AND PALYNOLOGICAL RECORDS}

\author{
RECERE \\ PEB 27 นิ้งิ \\ OSTI
}

Prepared for:

Mifflin \& Associates, Inc. 3980 N. Pecos Boulevard

Las Vegas, Nevada 89121
This study was funded by DOE grant number DE-FG08-85-NV10461.

October 5, 1994 


\section{TABLE OF CONTENTS}

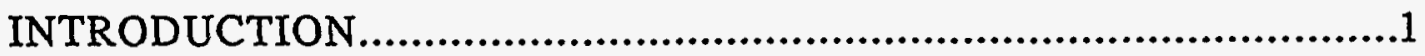

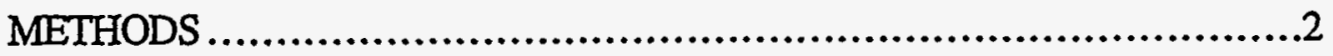

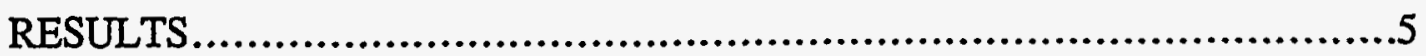

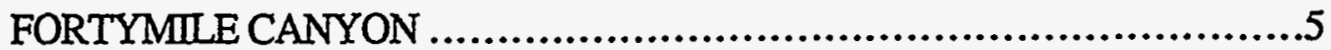

Age of The Fortymile Canyon Midden Samples...........................7

Paleoenvironments of The Middle Reaches of Fortymile

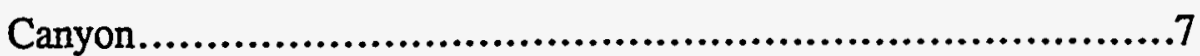

The Modern Pollen Data From Fortymile Canyon.................15

The Fossil Pollen Data From Fortymile Canyon...................17

Riparian Environments of Fortymile Canyon .....................22

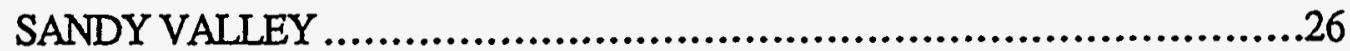

Age of The Sandy Valley Midden Samples................................26

Early Holocene Paleoenvironments............................................29

The Pollen Data From Sandy Valley..................................30

Riparian Environments of Northern Sandy Valley..................31

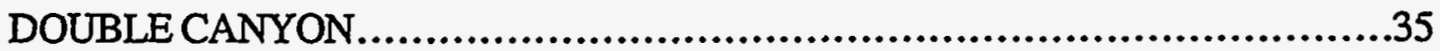

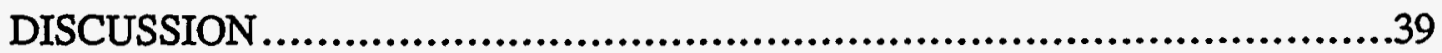

LATE QUATERNARY HYDROLOGIC VARIATIONS............................39

Local Evidence of Hydrologic Change Prior To The Last

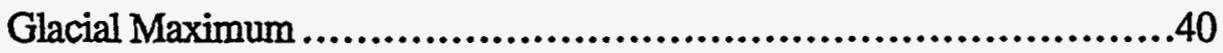

Local Evidence During The Last Glacial Maximum ...............41

The Regional Paleohydrologic Records....................................42

The Paucity of Regional Glacial-Maximum Records ..............43

Early Holocene Paleohydrologic Records ........................46

Evidence From Sandy Valley...................................47

SUMMARY AND RECOMMENDATIONS............................................48

RECOMMENDATIONS FOR FURTHER RESEARCH ........................49

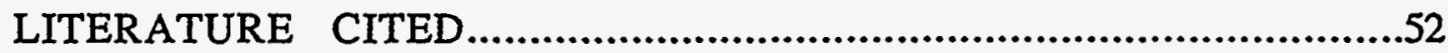

APPENDIX I: Data from the Fortymile Canyon locality ..............................58

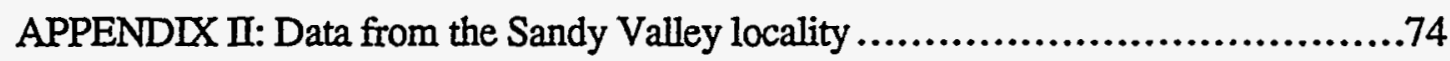

APPENDIX III: Data from the Double Canyon locality ................................78 


\section{LIST OF FIGURES}

Figure 1. The regional study area with localities mentioned in the text ................3

Figure 2. The middle reaches of Fortymile Canyon...................................6

Figure 3. Northern Sandy Valley ................................................27

Figure 4. The Double Canyon locality .........................................35B

\section{LIST OF TABLES}

Table 1. Midden Samples and Radiocarbon Dates from Fortymile Canyon.............8

Table 2. Selected Plant Species from the Fortymile Canyon middens. .................9

Table 3. Habitat Attributes of the Fortymile Canyon packrat midden sites .............12

Table 4. Similarity Matrix Comparing the Fortymile Canyon Middens..................14

Table 5. The Pollen Data from Modern Fortymile Canyon Packrat Middens ............16

Table 6. The Pollen Data from Ancient Fortymile Canyon Packrat Middens..............18

Table 7A. Paleohydrologic Indicators From Packrat Middens Dating ca.

15,900 to $>52,000$ B.P., and Near The Sites Today

Table 7B. Paleohydrologic Indicators From Packrat Middens Dating ca.

2,800 to 13,000 B.P., and Near The Sites Today ............................24

Table 8. Habitat Attributes of the Sandy Valley and Double Canyon Sites..............28

Table 9. Selected Plant Species from the Sandy Valley Packrat Middens ................29

Table 10. The Pollen Data from the Sandy Valley and Double Canyon samples ........32

Table 11. Macrofossil Records of Hydrophilic Species from Southern Nevada..........36

Table 12. Selected Plant Species From the Double Canyon Middens...................37

Table 13. Radiocarbon dates on paleospring Deposits: Units D and E....................44 


\section{INTRODUCTION}

The primary objective of this research in the vicinity of the proposed Yucca Mountain Nuclear Waste Repository is the detection of episodes of increased runoff and groundwater discharge in this presently arid area. Ancient, inactive spring deposits in nearby valley bottoms (Haynes, 1967; Quade, 1986; Quade and Pratt, 1989), evidence for perennial water in presently dry canyons (Spaulding, 1992), and recent claims for extraordinary increases in precipitation during the the last glacial age (Forester; 1994), provide good reason to further investigate both lowland spring-discharge habitats, and upland drainages. The ultimate purpose is to assess the long-term variability of the hydrologic system in the vicinity of Yucca Mountain in response to naturally occurring climatic changes. An understanding of this variability is important to an assessment of the performance of the proposed Yucca Mountain Repository, because it is reasonable to anticipate that pluvial climates (those characterized by significant and persistent increases in rainfall) will occur again within its design life (10,000 to 100,000 years; National Research Council, 1992). On one hand, if no evidence of exceptional increases in runoff and discharge is found, it would be considered a favorable finding from the point of view of hydrologic stability. On the other hand, if evidence is found for perennial water in currently-dry drainages, such as Fortymile Canyon on the west flank of Yucca Mountain, it would indicate that, at the least, provisions for substantially increased recharge rates, ground-water travel times, and instability of drainage systems need to be made.

The data generated in the course of this study are derived from radiocarbon dated packrat (Neotoma) middens. This report presents the results of an initial assessment of the hydrologic stability of the candidate area based on a limited suite of middens from localities that, on geomorphic and hydrologic grounds, could have been close to ancient stream-side or spring environments. Such riparian habitats have a distinctive flora composed of plants adapted to persistent, near-surface water (hydrophilic plants or phreatophytes). In the rugged terrain of the Candidate Area it is possible to locate midden sites near canyon-bottoms and paleospring sites. Today these habitats are, almost without exception, dry water courses or barren valley-bottom inselbergs. However, at certain times in the past, conditions were quite different. 
Paleoclimatic reconstructions are another means of studying the long-term climatic and hydrologic stability of the Candidate Area include, and are also generated from packrat midden data. A different flora characterized the Candidate Area during the last glacial age in response to a cooler and wetter climate, and the plant species that comprised this flora can be used to reconstruct specific components of past climatic regimes. Thus, a secondary objective of this study is to compare the plant macrofossil data generated in this study to other records from the Candidate Area (e.g. Spaulding, 1985; Wigand, 1990) to determine if these new data are consistent with prior reconstructions. Paleoenvironmental reconstructions can be tested only through attempts at replication. Prior models of relatively dry climatic conditions during the last glacial maximum (Spaulding, 1985), increased precipitation during the Wisconsin-Holocene transition (albeit only 100\% above modern; Spaulding et al., 1984; Spaulding and Graumlich, 1986), and new claims for up to a $400 \%$ increase in precipitation (Forester, 1994), all suggest the wisdom of continued investigations into how much wetter and colder it can become in the vicinity of Yucca Mountain over long periods of time.

\section{METHODS}

In this study, the localities targeted for midden collection were the middle reaches of Fortymile Canyon, immediately east of North Yucca Mountain, northern Sandy Valley immediately west of the southern Spring Range, and Double Canyon in the northern Arrow Canyon Range (Fig. 1). In the first and last areas, extensive drainage basins upstream of the midden localities could have resulted in perennial run-off during episodes of increased precipitation. In Sandy Valley, paleospring deposits within several hundred meters of the midden sites indicate increased discharge at some time in the past. Here middens can help further delineate the past extent of phreatophyte distribution and therefore changes in water-table elevation.

Techniques of packrat midden analysis and constraints of the midden data have been discussed elsewhere (see contributions in Betancourt et al., 1990; Spaulding, 1985). Briefly, an ancient packrat midden is an accumulation of primarily plant fragments and fecal pellets saturated by amberat (dehydrated packrat urine), with a consistency and mass resembling an unfired adobe brick. Aside from the geomorphic and hydrologic setting of the site, other criteria for selection of middens for this study included their degree of preservation, stratification, and relative age. The latter was determined by 


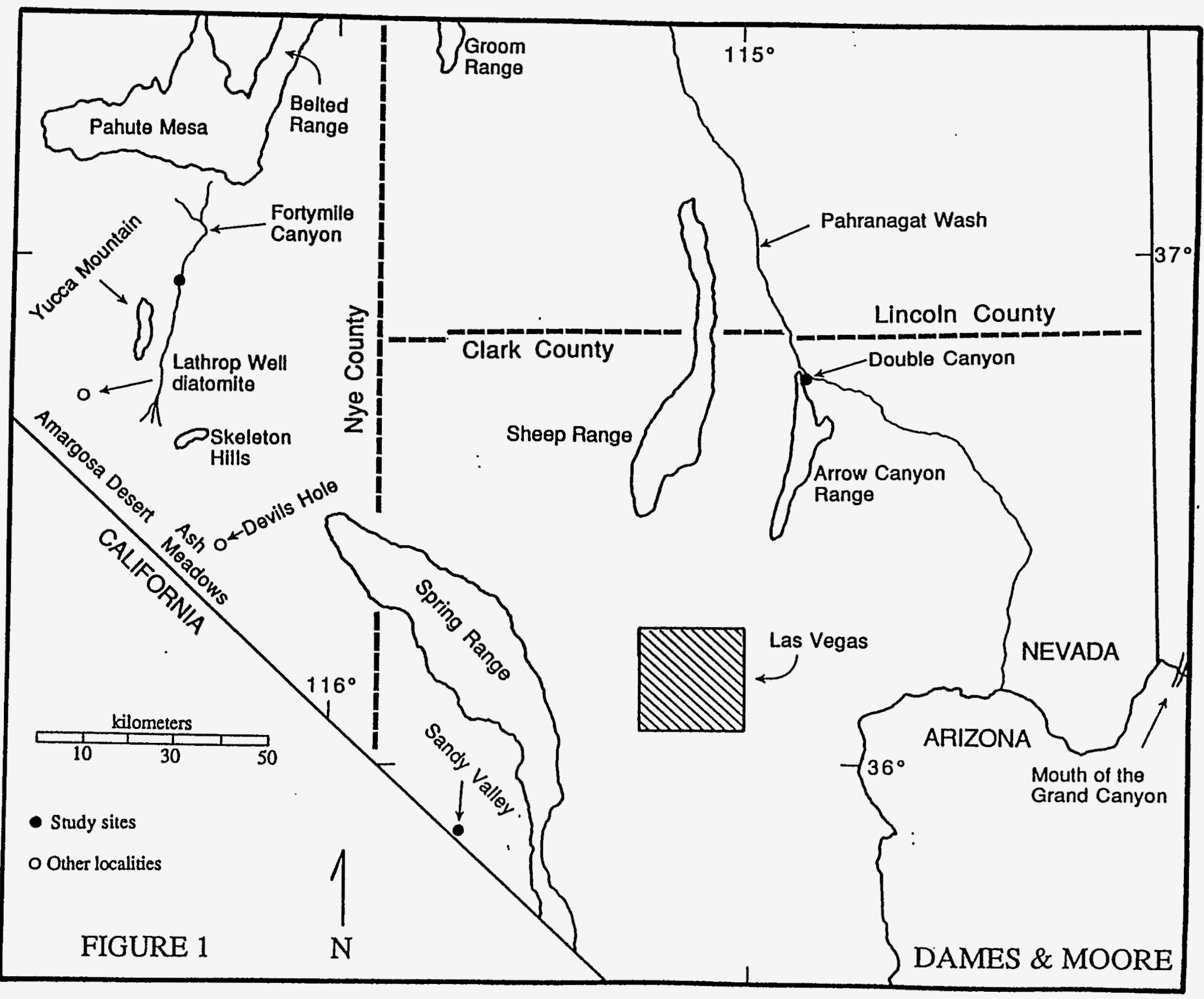


assessing the principal plant constituents of a midden. Because the middle and late Holocene (7,500 B.P. to present) were relatively arid (Spaulding, 1991a; Thompson et al., 1993), attention was focussed on those deposits that contained extralocal plant species and were therefore likely to date to the last (Wisconsin) glacial age (ca. 75,000 to 10,000 B.P.) or to the early Holocene (10,000 to 7,500 B.P.).

Along with the field recordation of the midden sites and collection of the ancient midden samples, a list of plants currently growing in the vicinity of the site was made and, if available, control samples of currently active packrat middens in the same rockshelters were collected. In the laboratory, the indurated midden samples were cleaned of weathering rind and adhering debris, further split into subsamples if their stratification warranted separation, weighed, and then immersed in water. Smaller subsamples of each sample selected for plant macrofossil analysis were saved for pollen analysis. After immersion in water for two to four days, the disaggregated samples were then washed through a series of nested soil sieves to capture the plant macrofossils and clean the mass of amberat and fine debris. After drying, the recovered remains were sorted and the plant macrofossils identified. Because the primary objective of this study was to determine whether phreatophytes were present, macrofossil abundance was not quantitatively determined. Instead, a subjectively assigned rank was assigned to each plant species encountered ( 5 , very abundant; 4 , abundant; 3 , common; 2 , occasional; 1 , rare).

Pollen analysis of selected midden subsamples was undertaken to determine if the pollen of phreatophytes could be detected. Because packrats have a limited foraging radius (ca. $30 \mathrm{~m}$ ), and because macrofossil assemblages from packrat middens are commonly dominated by rocky-slope plants, it was thought that palynology might provide an additional means of testing for the presence of hydrophilic plants nearby, but beyond the range of the packrat. Extraction of pollen from the ancient middens was accomplished by first suspending the sample in warm water for a limited period ( 15 to 45 minutes), until a sufficient quantity of fine sediment was released but before the packrat fecal pellets began to disaggregate. Sediment from the loose, modern midden samples was simply concentrated by dry sieving. This sediment was then subjected to standard sequence of treatments in acids and bases to concentrate the pollen and remove other organic remains and the mineral fraction (see Faegri and Iversen, 1985; Birks and Birks, 1980). A minimum of 350 pollen grains was counted from each sample. 
Final analyses of the extracted pollen samples were carried out by Dr. R. Scott Anderson of the Laboratory of Paleoecology, Bilby Research Center, Northern Arizona University. After preliminary analyses at the University of Washington, it was decided that Dr. Anderson's extensive experience in the identification of both wet-land pollen taxa (e.g., Anderson, 1990; Anderson et al., 1985), and in the analysis of pollen from packrat middens (e.g., Anderson and Van Devender, 1991) would be of value in determining the actual importance of the pollen of phreatophytic plant species in pollen assemblages that contain an abundance of types that are rarely seen in typical pollen samples (ibid.).

\section{RESULTS}

The results of analysis of the packrat midden samples from Fortymile Canyon, Sandy Valley, and Double Canyon are present below. The current vegetation and topographic setting of each locality is first discussed, followed by the results of analyses of the macrofossil and pollen samples, and then the paleohydrologic inferences that arise from these data.

\section{FORTYMILE CANYON}

Previous paleoenvironmental research in this drainage system has focussed on middens from shelters developed in Quaternary alluvium in the lower reaches of Fortymile Canyon (950 to 1,100 m elevation) in the upper creosote bush zone (Spaulding, 1990a; see Appendices I to III for the botanical names of plants mentioned in this study). All middens from this loosely consolidated alluvium were of late Holocene age $(<2,000$ B.P.), and provided no records of phreatophytic plant taxa. However, substantial downslope retreat of the upper limit of creosote bush occurred prior to ca. 1,200 B.P. as a result of a modest increase in effective moisture, and an increase in flood frequency has been inferred from the remains of disturbance-adapted species where they do not occur today (Spaulding, 1990a).

For this study, a new set of macrofossil records was obtained from higher elevation sites $(1,250$ to $1,310 \mathrm{~m})$ farther upstream in Fortymile Canyon, where the canyon is more constricted as bedrock walls confine its course (Figure 2). The Tertiary volcanic 


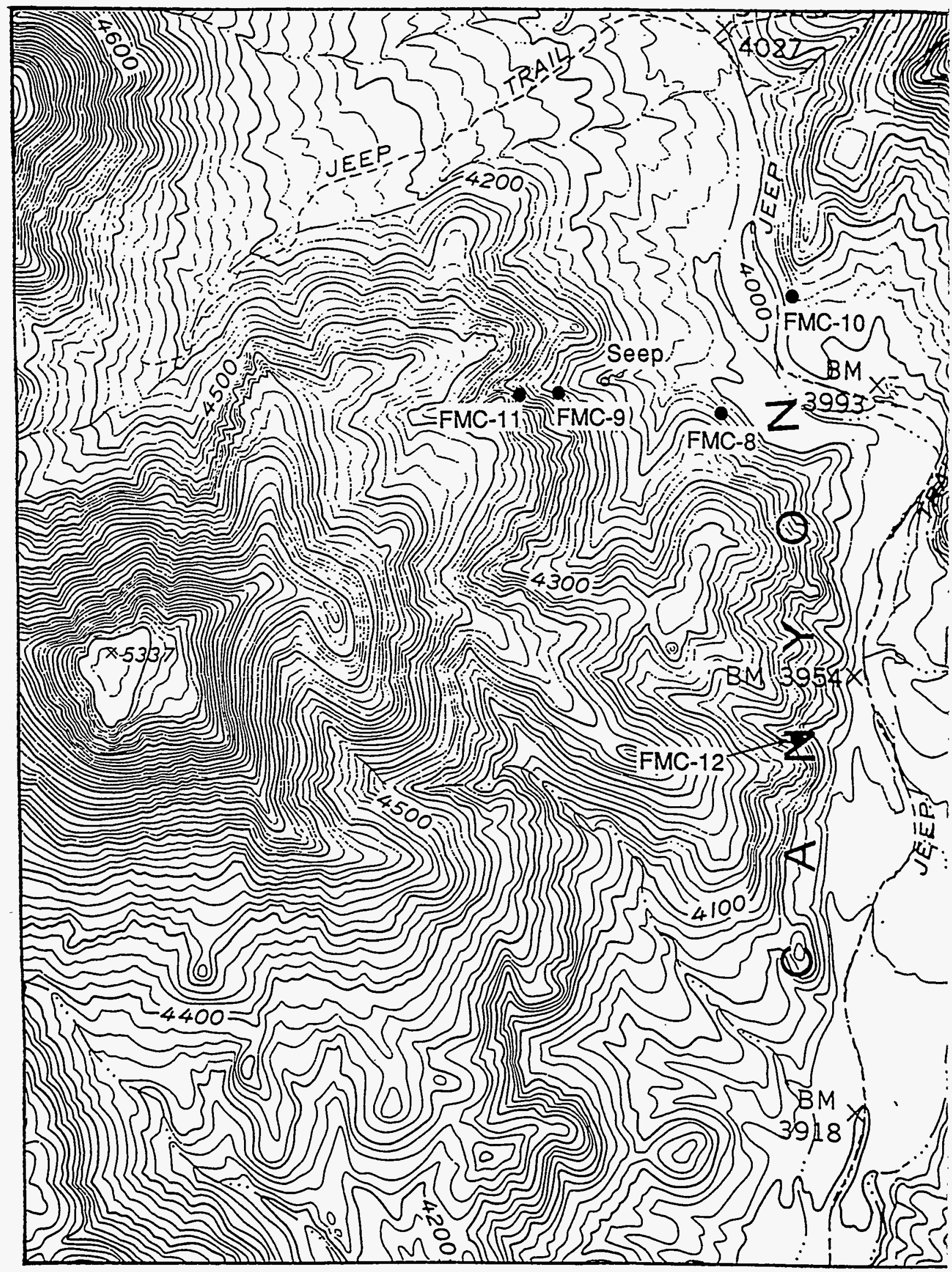




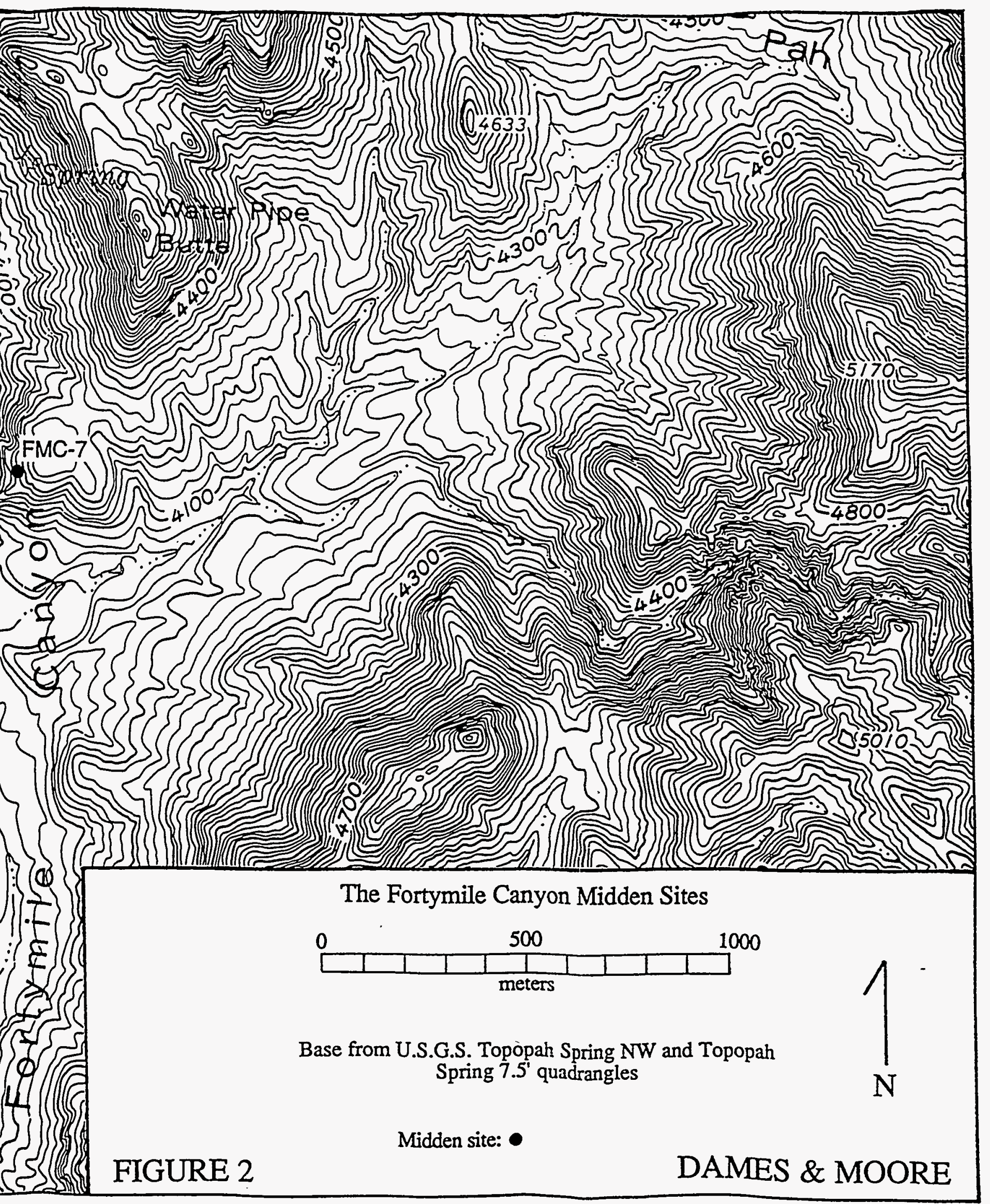


rocks here weather in such a fashion as to afford numerous rock shelters and cavities, and middens in these cavities evidently persist millennia longer than those recovered from Quaternary alluvium. The present vegetation of this area is mixed desert scrub characterized by such shrubs as goldenbush, California buckwheat, joint-fir and, on mesic slopes, blackbrush and tarragon. Riparian desert scrub (sensu Bradley and Deacon, 1967) in the bottom of Fortymile Canyon is typified by shrubs such as desert rabbitbrush, cheeseweed, bitterbrush, and big bursage (Appendix 1).

\section{Age of The Fortymile Canyon Midden Samples}

In the course of sorting the Fortymile Canyon middens, fecal pellets and twigs were collected from each sample and submitted for radiocarbon dating to the Quaternary Isotope Laboratory, Quaternary Research Center, University of Washington. The results showed that the samples from the Fortymile Canyon-7 (FMC-7) midden were very old $(47,240 \pm 3,000$ and $>52,000$ B.P.; Table 1). The younger sample (FMC-7(1)) comes from the top stratum of the midden but, at the limit of sensitivity of the radiocarbon technique, it is uncertain whether the ${ }^{14} \mathrm{C}$ date reflects the "real" sample age or contamination by a minute amount of younger carbon. But the FMC-7 samples contain a typically glacial floristic assemblage and, given decreasing midden frequency with increasing age (see Webb and Betancourt, 1990) it is unlikely that this deposit predates the beginning of the Early Wisconsin (oxygen isotope Stage 4: ca. 73,000 yr B.P.; Martinson et al., 1987). A date of ca. 21,800 B.P. on FMC-9A places it early in the Late Wisconsin stadial (ca. 23,300 to 10,000 B.P.; Spaulding, 1985), while three samples date to near the time of the last glacial maximum at ca. 18,000 B.P. (CLIMAP, 1981; Table 1). Dating of sample FMC-11B indicates an early deglacial age (Mix, 1987), while the two early Holocene samples from FMC-10 record conditions near the end of deglaciation (Table 1). A final sample, FMC-12B, judged in the field to be late Holocene in age but nevertheless containing relatively abundant Utah juniper, a mesophyte missing from the site today, yielded an age of ca. 2,800 B.P. (Table 1).

\section{Paleoenvironments of The Middle Reaches of Fortymile Canvon}

Table 2 presents a summary of the plant macrofossil data from the Fortymile Canyon middens. All trees and arborescent shrubs, as well as other montane or subalpine species and steppe shrubs are listed here. Other shrubs, succulents, annuals and grasses 
Table 1. Packrat Midden Samples and Radiocarbon Dates from Fortymile Canyon.

\begin{tabular}{|c|c|c|c|c|c|c|c|c|}
\hline Site Name and No. & N. lat. & W. long. & Elev. (m) & Sample No. & $\begin{array}{c}\text { 14-C date } \\
\text { (yr B.P.) }\end{array}$ & $\begin{array}{c}\text { Standard } \\
\text { deviation ( }( \pm)\end{array}$ & $\begin{array}{c}\text { Laboratory } \\
\text { number (QL-) }\end{array}$ & $\begin{array}{c}\text { Material } \\
\text { dated }\end{array}$ \\
\hline \multirow[t]{2}{*}{ Fortymile Canyon- 7} & $36^{\circ} 56^{\prime} 42^{\prime \prime}$ & $116^{\circ} 22^{\prime} 21^{\prime \prime}$ & 1280 & FMC-7(1) & 47,200 & 3,000 & 4,218 & $\mathrm{fp}, \mathrm{ju}$ \\
\hline & & & & FMC-7(3) & $>52,000$ & - & 4,233 & $\mathrm{fp}, \mathrm{ju}$ \\
\hline Fortymile Canyon- 8 & $36^{\circ} 56^{\circ} 49^{\prime \prime}$ & $116^{\circ} 22^{\prime} 46^{\prime \prime}$ & 1240 & FMC-8A & 18,530 & 80 & 4,219 & $\mathrm{fp}, \mathrm{sw}$ \\
\hline Fortymile Canyon- 9 & $36^{\circ} 56^{\prime} 49^{\prime \prime}$ & $116^{\circ} 23^{\prime} 01^{\prime \prime}$ & 1280 & FMC-9A & 21,830 & 110 & 4,220 & $\mathrm{fp}$ \\
\hline \multirow[t]{2}{*}{ Fortymile Canyon- 10} & $36^{\circ} 56^{\prime} 57^{\prime \prime}$ & $116^{\circ} 22^{\prime} 39^{\prime \prime}$ & 1230 & FMC-10A & 9,470 & 40 & 4,221 & $\mathrm{fp}$ \\
\hline & & & & FMC-10C & 9,390 & 40 & 4,222 & $\mathrm{fp}$ \\
\hline \multirow[t]{3}{*}{ Fortymile Canyon- 11} & $36^{\circ} 56^{\circ} 49^{\prime \prime}$ & $116^{\circ} 23^{\prime} 27^{\prime \prime}$ & 1310 & FMC-11A(1) & 15,870 & 70 & 4,223 & fp \\
\hline & & & & FMC-11A(2) & 16,410 & 70 & 4,234 & $\mathrm{fp}$ \\
\hline & & & & FMC-11B & 12,870 & 50 & 4,224 & $\mathrm{fp}$ \\
\hline Fortymile Canyon- 12 & $36^{\circ} 56^{\prime 2} 26^{\prime \prime}$ & $116^{\circ} 22^{\prime} 35^{\prime \prime}$ & 1240 & FMC-12B & 2,770 & 30 & 4,225 & fp \\
\hline \multirow[t]{3}{*}{ Sandy Valley- 2} & $35^{\circ} 52^{\prime} 40^{\prime \prime}$ & $115^{\circ} 42^{\prime} 28^{\prime \prime}$ & 935 & SAV-2(1)1 & 8,790 & 80 & 4,226 & fp, ut \\
\hline & & & & SAV-2(3)2 & 9,250 & 60 & 4,235 & fp, ut \\
\hline & & & & $\mathrm{SaV}-2(3) 3$ & 9,400 & 90 & 4,227 & fp \\
\hline \multirow[t]{2}{*}{ Sandy Valley- 3} & $35^{\circ} 52^{\prime} 40^{\prime \prime}$ & $115^{\circ} 42^{\prime} 25^{\prime \prime}$ & 885 & SAV-3(1) & 8,490 & 120 & 4,236 & od \\
\hline & & & & $\mathrm{SaV}-3(2)$ & 9,430 & 60 & 4,237 & od \\
\hline Double Canyon-1 & $36^{\circ} 47^{\prime} 05^{\prime \prime}$ & $114^{\circ} 53^{\prime} 04^{\prime \prime}$ & 660 & DC-1(1) & 12,060 & 70 & 4,228 & $\mathrm{fp}, \mathrm{ut}$ \\
\hline Double Canyon-4 & $36^{\circ} 46^{\prime} 50^{\prime \prime}$ & $114^{\circ} 52^{\prime} 53^{\prime \prime}$ & 690 & DC- $4(2)$ & 10,400 & 60 & 4,238 & od \\
\hline
\end{tabular}

fp, Neotoma fecal pellets; ju, juniper twigs and seeds; od, cleaned and sorted undifferentiated organic debris; sw, sagebrush wood; undifferentiated twigs 
Table 2. Selected Plant Species from the Fortymile Canyon packrat middens.

SITE AND SAMPLE: FMC-7(3) FMC-7(1) FMC-9A FMC-8A FMC-11A(2) FMC-11A(1) FMC-11B FMC-10A FMC-10C FMC-12B

\begin{tabular}{|c|c|c|c|c|c|c|c|c|c|c|c|c|}
\hline \multirow{2}{*}{\multicolumn{3}{|c|}{$\begin{array}{l}\text { APPROXIMATE 14-C AGE (B. P.): } \\
\text { TRERS AND ARBORESCENT SHRURS }\end{array}$}} & \multirow{2}{*}{$\geq 52,000$} & \multirow[t]{2}{*}{47,240} & \multirow[t]{2}{*}{21,830} & \multirow[t]{2}{*}{18,530} & \multirow[t]{2}{*}{16,410} & \multirow[t]{2}{*}{15,870} & \multirow[t]{2}{*}{12,870} & \multirow[t]{2}{*}{9.470} & \multirow[t]{2}{*}{9,390} & \multirow[t]{2}{*}{2,770} \\
\hline & & & & & & & & & & & & \\
\hline COMMON NAME & GENUS AND SPECIES & AFFINITY & & & & & & & & & & \\
\hline limber pino & Pinus flexilis & $n$, M/S & - & - & $\cdot$ & - & 1 & 1 & - & - & - & - \\
\hline mountain mahogany & Cercocarpus ledifolius & 1, M/S & 1 & - & 2 & 2 & 3 & 3 & 3 & - & - & - \\
\hline single-leaf ash & Fraxinus anomala & II & - & 1 & 1 & 1 & 1 & 1 & 2 & - & - & - \\
\hline single-leaf pinyon & Pinus monophylla & $!$ & tt & 3* & 1 & - & $1 *$ & 1 & $t$ & tt & 1 & - \\
\hline Utah juniper & Juniperus ostcosperms & 1 & 3 & $4^{*}$ & 5 & 4 & 3 & 4 & 3 & $4^{*}$ & 3 & 2 \\
\hline white fir & Abies concolor & $\| l, h_{1} M / S$ & - & - & - & - & - & tt & - & - & - & - \\
\hline willow..................... & 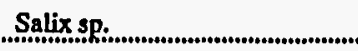 & ........................ & 2. & ....... & $\therefore$ & $\ldots$ & $\therefore . .$. & $\ldots$ & $\therefore . .$. & ........ & ........ & ....... \\
\hline \multicolumn{13}{|c|}{ OTHER MONTANE AND SUBALPINE SPECIES } \\
\hline dwarf ocean-spray & Holodiscus microphyllus & I, M/S & - & - & 1 & 1 & 1 & 1 & 1 & - & - & - \\
\hline fern bush & Chamaebatiaria millefolium & I. M/S & - & 1 & 1 & 1 & 1 & 1 & 1 & - & - & - \\
\hline pika (boteal mammai) & Ochotona sp. & $11, \mathrm{M} / \mathrm{S}$ & - & : & - & - & 1 & - & - & - & - & - \\
\hline raspberry & cf. Rubus sp. & II, M/S & - & 1 & - & - & - & - & - & - & - & - \\
\hline wild mint. & 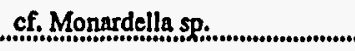 & . &... & $\ldots$ & $\ldots . . . .$. & $\ldots$ & $1 . . .$. & $\therefore . .$. & $1 .$. & $\therefore$ & $\therefore$ & $\therefore$ \\
\hline \multicolumn{13}{|l|}{ STEPPE SHRUBS } \\
\hline horsebrush & Tetradymia canescens-type & 1 & 2 & 1 & 2 & 1 & 2 & 1 & - & - & - & - \\
\hline rubber rabbitbrush & Chrysotharmus nauseosus & 1 & 3 & 1 & - & - & 1 & - & 1 & - & - & - \\
\hline sagebrush & Artemisia subgen. Tridentatao & - & 3 & 1 & 4 & 3 & 4 & 4 & 3 & 1 & - & - \\
\hline viscid rabbitbnsush. & Chrysothamnus viscidiffons & $\therefore .$. & 1. & ........ & 4. & 3 & 2 & 2 & $2 .$. &.... & $\therefore$ & $\therefore$ \\
\hline \multicolumn{13}{|c|}{ SELECTED SHRUBS AND SUCCULENTS } \\
\hline bitterbrush & Purshia glandulosa & - & - & - & - & - & - & - & 1 & 4 & 4 & 2 \\
\hline box-thom & Lycium cf. cooperi & - & $\cdot$ & $\cdot$ & - & - & - & - & - & - & - & 2 \\
\hline brickel-bush & Brickellia oblongifolia & - & - & - & 2 & - & 1 & 1 & 2 & - & - & - \\
\hline Califomia buckwheat & Eriogonum fasciculatum & - & - & - & - & - & - & - & - & - & - & 3 \\
\hline currant & Ribes sp. & 1 & 2 & 1 & - & 1 & - & - & - & - & - & - \\
\hline dwarf goldenbush & Haplopappus nanus & - & 2 & 3 & 1 & $->$ & - & - & - & - & - & - \\
\hline globe-mallow & Sphaeraicea ambigua & - & $\cdot$ & - & - & - & $\cdot$ & - & 2 & 2 & 1 & 1 \\
\hline goldenbush & Haplopappus linearifolius & - & - & - & - & - & - & - & - & 1 & 1 & 2 \\
\hline hop-sage & Grayia spinosa & - & - & - & 2 & 1 & - & - & - & - & - & - \\
\hline joint-fir & Ephedra cf. viridis & - & 2 & - & - & - & - & - & - & - & - & 3 \\
\hline plains prickly-pear & Opuntia cf. polyacantha & 1 & 3 & 2 & 3 & 1 & 3 & 1 & 3 & 4 & 3 & - \\
\hline prostrate buckwheat & Eriogonum caespitosum-type & - & - & - & 1 & 3 & - & - & - & - & - & - \\
\hline round-leaf rabbitbrush & Chrysothannus teretifolius & - & - & - & - & - & - & - & - & - & - & 3 \\
\hline sage & Salvia donrii & 1 & 2 & 1 & - & - & 2 & 1 & 1 & - & - & - \\
\hline
\end{tabular}


Table 2 (continued)

STIE AND SAMPLE: FMC-7(3) FMC-7(1) FMC-9A FMC-8A FMC-11A(2) FMC-11A(1) FMC-11B FMC-10A FMC-10C FMC-12B

\begin{tabular}{|c|c|c|c|c|c|c|c|c|c|c|c|c|}
\hline & APPROXIMATI & AGE (B. P.): & $>52,000$ & $47,240^{\circ}$ & 21,830 & 18,530 & 16,410 & 15,870 & 12,870 & 9,470 & 9,390 & 2,770 \\
\hline silvery lupine & Lupinus argenteus-typo & 1 & $\cdot$ & - & - & 1 & 1 & 2 & 1 & - & - & - \\
\hline snake-weed & Gutierrezia microcephala & - & - & - & - & - & - & - & - & - & - & 2 \\
\hline tarragon & Artemisia dracunculus & - & - & - & - & - & - & - & - & 2 & 3 & 1 \\
\hline wild-rose & Rosa woodsii & $\mathrm{l}, \mathrm{h}$ & 2 & 1 & - & - & - & - & - & - & - & - \\
\hline \multicolumn{13}{|c|}{ SELECTED HERBS, FORBS, AND GRASSES } \\
\hline COMMON NAME & GENUS AND SPECIES & AFFINITY & & & & & & & & & & \\
\hline thistle & Cirsium sp. & - & 1 & 1 & - & - & - & - & - & 2 & 2 & 1 \\
\hline spectacle-pod & Thysanocarpus curvipes & 1 & - & - & - & - & - & - & - & 2 & 2 & - \\
\hline wish-bone plant & Mirabilis cf. bigelovii & - & - & 2 & - & - & - & - & . & - & - & - \\
\hline plantain & Plantago cf. patagonica & - & - & - & - & - & - & - & - & 1 & 2 & 1 \\
\hline grasses & Poaceae undifferentiated & - & - & 1 & 1 & 2 & 1 & 1 & 1 & 2 & 1 & 1 \\
\hline
\end{tabular}

Relative Abundance Values: 1, rare; 2, occasional; 3, common; 4, abundant; 5, very abundant

t nut shell fragments only, not tallied in Nts or $\mathrm{N}_{\text {; }}$ f ono fragment only, not tallied in $\mathrm{Nts}$ or $\mathrm{N}_{\mathrm{i}}$ * observed in fecal pellets

I- extralocal species; II- extralimital species; H- obligate hydrophile or phreatophyte; h- facultative hydrophile or phreatophyte; M/S- montane or subalpine taxon 
are also listed if they are "occasional" (relative abundance rank of 2) in at least one sample (Table 2). The complete data from these middens is presented in Appendix I. Glacial-age macrofossil assemblages from the middle reaches of Fortymile Canyon (Figure 2) indicate an open woodland typified by Utah juniper, mountain mahogany, steppe shrubs, and plains prickly-pear. Single-leaf ash, single-needle pinyon, and fern bush also occur in most of these samples, albeit in minor quantities.

The Middle Wisconsin(?) FMC-7 samples provide the only assemblages to contain appreciable amounts of currant and dwarf goldenbush, and the only samples that yield the remains of willow and wild-rose. The presence of the latter two species is explicable in terms of a radically different local hydrology, which will be discussed below. Sample FMC-7(1), at ca. 47,000 B.P., is also the only assemblage to contain the common remains of pinyon. All younger samples contain only rare pinyon at best (Table 2), including those from the last glacial maximum. This is consistent with reconstructions that place pinyon near the northern limit of its distribution in this area during the Late Wisconsin stadial (Spaulding, 1990a; Thompson, 1988). Warmer temperatures during the prior Middle Wisconsin interstadial and, perhaps, increased summer moisture relative to the Late Wisconsin allowed pinyon to assume importance here. From this, it appears reasonable to suggest that pinyon may have ranged farther north into the present Great Basin floristic region during the last interstadial.

A trend toward colder and drier conditions is indicated by the plant macrofossil assemblages dating from ca. 21,800 to ca. 15,900 B.P. Several montane or subalpine species occur only in these, including limber pine, white fir, and the small boreal mammal, pika (Table 2). These species are now extinct in the area. Limber pine and white fir occur as low as ca. 2,300 m elevation on similar volcanic rocks in the Groom Range, ca. $80 \mathrm{~km}$ to the northeast (Beatley, 1976). Pika, on the other hand,is currently restricted to elevations above ca. $2,900 \mathrm{~m}$ elevation, and the closest population of this boreal mammal is found on the high Toquima Range, ca. $165 \mathrm{~km}$ to the north.

Despite these records, aridity is indicated by the relative increase in sagebrush and viscid rabbitbrush in these stadial-age assemblages, as well as by the presence of hop-sage in FMC-8A and FMC-9A. The occurrence of this xerophytic member of the saltbush family in full-glacial assemblages is rather surprizing, but certainly consistent with the thesis of a relatively dry full-glacial climate. Sagebrush is more common than Utah 
Table 3. Habitat Attributes of the Fortymile Canyon packrat midden sites Discussed in This Report.

\begin{tabular}{|c|c|c|c|c|c|c|c|c|c|c|c|}
\hline \multirow[b]{2}{*}{ Site name and no. } & \multirow{2}{*}{$\begin{array}{l}\text { Elev. above } \\
\text { channel }\end{array}$} & \multirow{2}{*}{$\begin{array}{l}\text { Dist. to } \\
\text { channel }\end{array}$} & \multicolumn{3}{|c|}{ Site's primary habitat } & \multicolumn{3}{|c|}{ Secondary habitat } & \multicolumn{3}{|c|}{ Tertiary habitat } \\
\hline & & & Type & Aspect & Area & Type & Aspect & Area & Type & Aspect & Area \\
\hline Fortymile Canyon- 7 & 75 & 100 & lj,tc & $260^{\circ}$ & $60 \%$ & $\mathrm{rtp}$ & - & $30 \%$ & cl & $260^{\circ}-300^{\circ}$ & $10 \%$ \\
\hline Fortymile Canyon- 8 & 10 & 40 & stc & $38^{\circ}$ & $70 \%$ & $\mathrm{lj}, \mathrm{rtp}$ & - & $30 \%$ & - & - & - \\
\hline Fortymile Canyon- 9 & 60 & 410 & $c l, l j$ & $340^{\circ}-180^{\circ}$ & $60 \%$ & ts, lj & $15^{\circ}-25^{\circ}$ & $40 \%$ & - & - & - \\
\hline Fortymile Canyon- 10 & 10 & 20 & is & $193^{\circ}$ & $40 \%$ & lj, rtp & - & $30 \%$ & $\mathrm{cl}, \mathbf{l j}$ & $245^{\circ}$ & $30 \%$ \\
\hline Fortymile Canyon- 11 & 85 & 490 & $\mathrm{lj}, \mathrm{tc}$ & $332^{\circ}$ & $70 \%$ & cl,lj & $340^{\circ}-180^{\circ}$ & $30 \%$ & - & - & - \\
\hline Fortymile Canyon- 12 & 40 & 130 & $\mathrm{lj}, \mathrm{cl}$ & $85^{\circ}$ & $50 \%$ & cl, lj & $20^{\circ}-60^{\circ}$ & $25 \%$ & $\mathrm{lj}, \mathrm{ts}$ & $90^{\circ}-200^{\circ}$ & $25 \%$ \\
\hline
\end{tabular}

Abbreviations are: cl, cliff; $1 \mathrm{j}$, bedrock ledges; rtp, ridge top; stc, stabilized, colluvial slope; $t c$, rubbly talus chutes; ts, talus slopes. All sites are on the Older Rhyolites of Fortymile Canyon (Lundstrom and Warren, 1994; the Rhyolite of Vent Pass (Orkild and O'Connor, 1970)).

"Channel" refers to the current course of the Fortymile Canyon drainage.

Note that all elevations and distances are in meters, and based on calculations from $7.5^{\prime}$ topographic maps 
juniper in FMC-11A(2) (ca. 16,400 B.P.; Table 2), suggesting open vegetation and relative aridity. Indications of open vegetation conditions are unusual for glacial-age macrofossil assemblages above ca. 1,000 m elevation (Spaulding, 1983), but the FMC11 site has a xeric, westerly to southerly aspect (Table 3). Studies of full-glacial middens from different aspects at lower elevations reveal that southwest slopes supported desert scrub (Spaulding, 1990a,b), and this record indicates relatively open vegetation conditions on xeric slopes continuing up the elevational gradient from ca. 910 $\mathrm{m}$ to $1,310 \mathrm{~m}$.

The presence of single-leaf ash (Fraxinus anomala) in all but one of the glacial-age Fortymile Canyon assemblages deserves special mention (Table 2). A small tree common in the woodlands of the Colorado Plateau, its presence in these macrofossil assemblages suggests that it may have been common in parts of the northern Mojave Desert during the last glacial age. This could be inferred from the relict populations of single-leaf ash on several Mojave Desert mountain ranges (Beatley, 1976; Bradley and Deacon, 1967; Peterson, 1984). However, prior to this study, only one fossil record of this species had been reported from the Mojave Desert west of the Grand Canyon (Wells and Berger, 1967). With respect to paleohydrologic reconstructions, in the Colorado Plateau today single-leaf ash can be found on rocky slopes well-removed from water sources. This indicates that the Fraxinus pollen (which cannot be identified to species) recovered from the Fortymile Canyon middens (see below), although possibly attributable to the hydrophilic species velvet ash ( $F$. velutina), more likely belongs to the xerophytic single-leaf ash.

By ca. 12,900 B.P. deglacial vegetation change had led to the extirpation of horsebrush, and the immigration of bitterbrush, tarragon, and globe-mallow (FMC-11B ; Table 2), species are common in the area today. Juniper and prickly-pear remain common to abundant in the early Holocene FMC-10 assemblages, but other mesophytes and virtually all steppe shrubs had disappeared from the area by ca. 9,500 B.P. Annuals such as thistle make their first appearance since the middle Wisconsin (Table 2). The diversity of herbs, forbs, and grasses in the early Holocene assemblages rises to more than $50 \%$ from a glacial-age average of $37 \%( \pm 7 \%$ at $1 \sigma)$. 
Table 4. Similarity Matrix Comparing the Composition of the Fortymile Canyon Packrat Middens.

\begin{tabular}{rccccccccc} 
Sample & FMC-7(3) & FMC-7(1) & FMC-9A & FMC-8A & FMC-11A(2) & FMC-11A(1) & FMC-11B & FMC-10A & FMC-10C \\
Apprx. age & $>52,000$ & 47,240 & 21,830 & 18,530 & 16,410 & 15,870 & 12,870 & 9,470 & 9,390 \\
\hline FMC-12B & 11 & 10 & 6 & 6 & 6 & 6 & 23 & 40 & 38 \\
FMC-10C & 19 & 24 & 28 & 14 & 27 & 28 & 34 & 75 & - \\
FMC-10A & 28 & 26 & 22 & 22 & 29 & 30 & 44 & - & - \\
FMC-11B & 53 & 56 & 56 & 56 & 73 & 69 & - & - & - \\
FMC-11A(1) & 41 & 50 & 69 & 63 & 91 & - & - & - & - \\
FMC-11A(2) & 46 & 54 & 67 & 61 & - & - & - & - & - \\
FMC-8A & 47 & 50 & 69 & - & - & - & - & - & - \\
FMC-9A & 47 & 56 & - & - & - & - & - & - & - \\
FMC7(1) & 79 & - & - & - & - & - & - & - & - \\
\hline
\end{tabular}

The similarity index used is that of Sorensen (1948); only the remains of trees, shrubs, and succulents were used in calculating similarity indices. 
Despite the presence of Utah juniper in FMC-12B, this late Holocene assemblage is much different from those dating to the last glacial age, and displays less than $50 \%$ similarity with the early Holocene samples (Table 4). Plants present only in this assemblage include box-thom, California buckwheat, round-leaf rabbitbrush, and snake-weed (Table 2). The lowest junipers in this area extend down to ca. 1,430 m elevation. However, in spite of a depression of the lower limit of juniper of $>180 \mathrm{~m}$, and consequent implications for increased precipitation ca. 2,800 yr B.P., the vegetation represented by FMC-12B indicates the most xeric conditions during this period of record.

\section{The Modern Pollen Data From Fortymile Canyon}

Understanding the pollen spectra that are characteristic of modern packrat middens in this area is, of course, important in interpreting the pollen from ancient middens. Six modern samples from five rock shelters, also yielding ancient middens, were analyzed (Table 5). Arboreal pollen (AP; chiefly Pinus (pine) and Juniperus (juniper) was relatively scarce in these modern samples; less than $10 \%$ in all except one (FMC-9.2, $\Sigma \mathrm{AP}=11.4 \%$ ). Ephedra viridis-type (joint-fir) and Cheno-am pollen (saltbush or amaranth) display relatively uniform percentages of 4.5 to $7.7 \%$ and 8.1 to $10.9 \%$ (one outlier at $2.3 \%$ ), respectively. Artemisia (sagebrush) is relatively important in three samples (17.9 to 23.2\%), and less common in the three other samples (4.2 to $11.4 \%$ ). "Hi-spine Asteraceae" is the most abundant pollen type in five of the six modern samples (Table 5). This pollen type comes from insect-pollinated genera of the sunflower family, and its relative abundance is attributable to the transport of flowers to the middens by packrats. Poaceae (grass pollen) is occasional in five samples ( 2.1 to $5.7 \%)$, and rare $(0.6 \%)$ in the sixth.

These modern control samples provide a means of assessing the significance of the pollen of hydrophilic plants present in the fossil samples (see below). Of importance here is the relative representation of pollen grains that do not come from the immediate vicinity of Fortymile Canyon, but that represent long-distance transport. Single grains of the trees cf. Eucalyptus (eucalyptus), Fraxinus (ash), Corylus (hazel), and Alnus (alder) must have been transported many tens of kilometers to this locality. The first two are common ornamentals in the urbanized areas of southern Nevada. The latter two are much less common in urbanized settings, and the nearest large populations of these 
Table 5. The Pollen Data from Modern Packrat Middens Collected At the Fortymile Canyon sites.

Sample: $\quad$ FMC 7.2 $\quad$ FMC 8.1 $\quad$ FMC 9.1 $\quad$ FMC 9.2 $\quad$ FMC 10.2 $\quad$ FMC 12.1

\begin{tabular}{|c|c|c|c|c|c|c|}
\hline Pollen Sum & 379 & 353 & 421 & 423 & 358 & 351 \\
\hline Sample Concentration & $88,982.6$ & $72,204.5$ & $811,928.6$ & $196,913.8$ & $439,363.6$ & $160,627.1$ \\
\hline Taxa Richness & 25 & 23 & 28 & 30 & 27 & 25 \\
\hline Tracers & 115 & 132 & 14 & 58 & 22 & 59 \\
\hline Deteriorated & 1.6 & 2.5 & 2.6 & 4.0 & 3.9 & 4.6 \\
\hline Unknown & 0.8 & 0.6 & 0.5 & 0 & 0.6 & 0.3 \\
\hline \multicolumn{7}{|l|}{ Arboreal Pollen (AP) } \\
\hline Pinus undifferentiated & 1.6 & 0.6 & 1.9 & 1.7 & 0.8 & 1.1 \\
\hline Pinus pinyon-type & 4 & 0.6 & 2.1 & 1.9 & 1.4 & 2.8 \\
\hline Juniperus & 2.4 & 3.4 & 2.9 & 7.8 & 0.8 & 3.7 \\
\hline cf. Eucalyptus & 0.3 & 0 & 0 & 0 & 0 & 0 \\
\hline Fraxinus & 0 & 0 & 0.2 & 0 & 0 & 0 \\
\hline Alnus & 0.3 & 0 & 0 & 0 & 0 & 0 \\
\hline Salix & 0 & 0.3 & 0 & 0 & 0 & 0 \\
\hline Corylus & 0 & 0.3 & 0 & 0 & 0 & 0 \\
\hline$\sum \mathrm{AP}$ & 8.6 & 5.2 & 7.1 & 11.4 & 3.0 & 7.6 \\
\hline Ephedra viridis-type & 7.7 & 5.9 & 4.5 & 4.5 & 7.5 & 6.6 \\
\hline Ephedra other & 0.3 & 0 & 0 & 0.5 & 0 & 0 \\
\hline Sarcobatus & 0.3 & 0 & 0 & 0 & 0 & 0 \\
\hline Cheno-Am & 10.8 & 2.3 & 8.1 & 8.7 & 10.9 & 10.5 \\
\hline Artemisia & 17.9 & 23.2 & 21.1 & 10.9 & 4.2 & 11.4 \\
\hline Asteraceae Hi-Spine & 25.1 & 6.2 & 23.8 & 18.7 & 27.9 & 25.9 \\
\hline Ambrosia & 14.0 & 13.6 & 9.3 & 5.0 & 12.8 & 9.4 \\
\hline Sphaeralcea & 0.5 & 1.1 & 1.4 & 0.2 & 4.7 & 0.3 \\
\hline Rosaceae & 0.8 & 0.3 & 0.5 & 0.2 & 0.6 & 0 \\
\hline Purshia/Cerocarpus-type & 1.3 & 18.1 & 3.6 & 6.6 & 0.6 & 4.3 \\
\hline Holodiscus-type & 1.3 & 1.1 & 0.5 & 2.1 & 0 & 0.9 \\
\hline Ceanothus & 0 & 0 & 0.5 & 0 & 0 & 0 \\
\hline Larrea & 0 & 0 & 0 & 0.2 & 0 & 0 \\
\hline cf. Yucca & 0 & 0 & 0 & 0.5 & 0.3 & 0.3 \\
\hline Lycium & 0 & 0 & 0 & 0 & 0.6 & 0 \\
\hline Shepherdia & 0 & 0 & 0 & 0 & 0.3 & 0 \\
\hline Scopulophila & 0 & 0 & 0 & 0 & 0 & 0.3 \\
\hline Platyopuntia & 0.3 & 0.6 & 0.7 & 0.2 & 0.6 & 0.6 \\
\hline Echinocerus-type & 0 & 0.3 & 0.2 & 0 & 4.5 & 0.3 \\
\hline Poaceae & 2.4 & 5.7 & 2.1 & 5.4 & 0.6 & 3.7 \\
\hline Boraginaceae & 0.5 & 0 & 0 & 0 & 0 & 0 \\
\hline Brassicaceae & 0.3 & 1.4 & 1 & 1.9 & 0 & 0.3 \\
\hline Fabaceae & 0.3 & 2.0 & 0 & 3.1 & 1.1 & 2.8 \\
\hline Eriogonum & 2.9 & 8.8 & 2.9 & 5.4 & 7.5 & 4.3 \\
\hline Gilia & 0.3 & 0.3 & 0 & 0.5 & 0 & 0.6 \\
\hline Leptodactylon & 2.1 & 0.6 & 6.2 & 6.9 & 0.8 & 2.8 \\
\hline Polemonium & 0 & 0 & 0 & $0: 5$ & 0.8 & 0 \\
\hline Lamiaceae & 0 & 0 & 0 & 0.2 & 0.3 & 0.3 \\
\hline
\end{tabular}


Table 5 (continued)

\begin{tabular}{|c|c|c|c|c|c|c|}
\hline Sample: & FMC 7.2 & FMC 8.1 & FMC 9.1 & FMC 9.2 & FMC 10.2 & FMC 12.1 \\
\hline Hydrophyllaceae & 0 & 0 & 0 & 0 & 0.3 & 0 \\
\hline Phacelia & 0 & 0 & 0.2 & 0.2 & 0 & 0.3 \\
\hline Caryophyllaceae & 0 & 0 & 0.5 & 0 & 0 & 0 \\
\hline Chorizanthe & 0 & 0.3 & 0 & 0.2 & 0.6 & 0 \\
\hline Cirsium & 0 & 0 & 0.5 & 0.2 & 4.5 & 0 \\
\hline Senecio-type & 0 & 0 & 0.2 & 0 & 0.3 & 0 \\
\hline Astragalus-type & 0 & 0 & 0.5 & 0.2 & 0 & 1.4 \\
\hline Aplaceae & 0 & 0 & 0.2 & 0 & 0 & 0 \\
\hline Geraniaceae & 0 & 0 & 1 & 0.5 & 0 & 0 \\
\hline cf. Euphorbia & 0 & 0 & 0.5 & 0.9 & 0.3 & 0 \\
\hline Datura & 0 & 0 & 0 & 0 & 0 & 0.3 \\
\hline \multicolumn{7}{|l|}{ Hydrophile Pollen } \\
\hline Alnus & 0.3 & 0 & 0 & 0 & 0 & 0 \\
\hline Salix & 0 & 0.3 & 0 & 0 & 0 & 0 \\
\hline Corylus & 0 & 0.3 & 0 & 0 & 0 & 0 \\
\hline Typha & 0.3 & 0 & 0 & 0 & 0 & 0 \\
\hline$\sum$ Hydrophile Pollen & 0.6 & 0.6 & 0 & 0 & 0 & 0 \\
\hline
\end{tabular}

species upwind of the Yucca Mountain area are in the Sierra Nevada. Long-distance transport must also be attributed to the single grains of Typha (cat-tail) and Salix (willow; Table 5). The only seep found within a kilometer of the study area (Figure 2) does not support these species. Instead, a thicket of net-leaf hackberry grows there, a taxon that was not encountered in the Fortymile Canyon pollen samples. These data demonstrate that, even in an arid climatic setting, occasional grains of phreatophyte pollen are to be expected in packrat middens, and such single-grain occurrences do not indicate the nearby presence of perennial water.

\section{The Fossil Pollen Data From Fortymile Canyon}

Increased proportions of arboreal pollen (AP), relative to those found in the control samples from Fortymile Canyon, distinguish the pollen spectra of all ancient midden samples, including those of early and late Holocene age (Table 6). However, the highest frequencies of AP pollen are not found in the full-glacial samples ( $\Sigma \mathrm{AP}=15$ to $30 \%$ ), but in the latest Wisconsin FMC-11B sample (50\%), and the Middle Wisconsin FMC7(1) sample (46\%). A single Abies (fir) grain in FMC-11A(1) is matched by a single fir needle in the macrofossil assemblage from that midden stratum (Tables 2,6), indicating the presence of fir somewhere in the immediate vicinity. 
Table 6. The Pollen Data From Ancient Packrat Midden Samples From Fortymile Canyon.

Sample: FMC 7(3) FMC 7(1) FMC 9A FMC 11A(2) FMC 11A(1) FMC 11B FMC 10A(1) FMC 10C(2) FMC 12B

\begin{tabular}{|c|c|c|c|c|c|c|c|c|c|}
\hline Approximate Age (yx B.P.) & $>52,000$ & 47,200 & 21,830 & 16,410 & 15,870 & 12,870 & 9,470 & 9,390 & 2,770 \\
\hline Pollen Sum & 364 & 363 & 353 & 360 & 355 & 361 & 350 & 359 & 375 \\
\hline Sample Concentration & 96352.9 & 980100 & 2476 & 60000 & 30525.5 & 14044.7 & 37800 & 47748.8 & 22351 \\
\hline Taxa Richness & 29 & 27 & 17 & 21 & 24 & 25 & 21 & 19 & 21 \\
\hline Tracers & 102 & 10 & 391 & 162 & 314 & 694 & 250 & 203 & 453 \\
\hline Deteriorated & 3.3 & 3.3 & 3.4 & 4.4 & 2.8 & 4.2 & 4.6 & 1.1 & 1.6 \\
\hline Unknown & 2.7 & 0.0 & 0.0 & 0.3 & 1.4 & 0.8 & 0.6 & 0.0 & 0.0 \\
\hline \multicolumn{10}{|l|}{ Arboreal Pollen (AP) } \\
\hline Abies & 0.0 & 0.0 & 0.0 & 0.0 & 0.3 & 0.0 & 0.0 & 0.0 & 0.0 \\
\hline Picea & 0.0 & 0.0 & 0.0 & 0.0 & 0.0 & 0.0 & 0.0 & 0.3 & 0.0 \\
\hline Pinus Haploxylon & 0.0 & 0.0 & 0.0 & 0.0 & 1.7 & 0.0 & 0.0 & 0.0 & 0.0 \\
\hline Pinus Diploxylon & 0.3 & 0.0 & 0.0 & 0.0 & 0.0 & 0.3 & 0.0 & 0.0 & 0.0 \\
\hline Pinus undifferentiated & 0.8 & 1.1 & 1.4 & 3.1 & 2.3 & 3.6 & 1.1 & 0.0 & 3.2 \\
\hline Pinus pinyon-type & 1.9 & 15.7 & 4.8 & 0.6 & 9.0 & 3.6 & 6.0 & 18.7 & 2.4 \\
\hline Juniperus & 9.3 & 26.4 & 22.1 & 9.2 & 15.8 & 40.2 & 13.7 & 16.7 & 32.5 \\
\hline Fraxinus & 0.3 & 1.1 & 0.0 & 1.7 & 0.6 & 1.4 & 0.0 & 0.0 & 0.0 \\
\hline Populus & 0.0 & 0.3 & 0.0 & 0.0 & 0.0 & 0.3 & 0.0 & 0.3 & 0.0 \\
\hline Salix & 0.0 & 1.4 & 0.0 & 0.6 & 0.3 & 0.6 & 0.3 & 0.0 & 0.0 \\
\hline$\sum$ AP & 12.6 & 46.0 & 28.3 & 15.2 & 30.0 & 50.0 & 21.1 & 36.0 & 38.1 \\
\hline Ephedra viridis-type & 0.3 & 0.0 & 0.0 & 0.6 & 0.3 & 0.6 & 0.6 & 0.0 & 4.0 \\
\hline Ephedra other & 0.0 & 0.0 & 0.0 & 0.0 & 0.0 & 0.0 & 0.0 & 0.3 & 0.0 \\
\hline Cheno-Am & 2.2 & 1.4 & 2.5 & 1.1 & 5.1 & 2.8 & 1.1 & 0.6 & 10.7 \\
\hline Artemisia & 48.9 & 14.0 & 24.9 & 42.2 & 42.3 & 12.5 & 24.6 & 12.8 & 4.3 \\
\hline Asteraceae Hi-Spine & 9.3 & 14.6 & 34.3 & 28.6 & 9.3 & 17.7 & 11.1 & 3.1 & 13.6 \\
\hline Ambrosia & 0.8 & 4.1 & 0.8 & 0.6 & 0.3 & 0.8 & 3.1 & 1.4 & 12.8 \\
\hline Sphaeralcea & 0.5 & 0.0 & 0.0 & 0.0 & 0.0 & 0.0 & 2.6 & 0.8 & 0.0 \\
\hline Rosaceae & 0.3 & 2.2 & 0.0 & 0.0 & 0.0 & 0.0 & 0.6 & 0.3 & 0.0 \\
\hline Purshia/Cercocarpus-type & 0.3 & 0.0 & 0.3 & 1.7 & 1.4 & 1.4 & 0.6 & 33.4 & 2.7 \\
\hline Holodiscus-type & 2.5 & 1.4 & 2.3 & 0.3 & 0.6 & 1.4 & 0.3 & 0.0 & 0.5 \\
\hline Rubus & 0.0 & 0.3 & 0.0 & 0.0 & 0.0 & 0.0 & 0.0 & 0.0 & 0.0 \\
\hline
\end{tabular}


Table 6 (continued)

Sample: FMC 7(3) FMC 7(1) FMC 9A(1) FMC 11A(2) FMC 11A(1) FMC 11B FMC 10A(1) FMC 10C(2) FMC 12B

\begin{tabular}{|c|c|c|c|c|c|c|c|c|c|}
\hline Approximate Age (yr B.P.) & $>52,000$ & 47,200 & 21,830 & 16,410 & 15,870 & 12,870 & 9,470 & 9,390 & 2,770 \\
\hline Prunus & 0.0 & 0.3 & 0.0 & 0.0 & 0.0 & 0.0 & 0.0 & 0.0 & 0.0 \\
\hline Lycium & 0.0 & 0.0 & 0.0 & 0.0 & 0.0 & 0.0 & 0.0 & 1.9 & 0.3 \\
\hline Symphoricarpos & 0.0 & 0.0 & 0.0 & 0.0 & 0.0 & 0.3 & 0.0 & 0.0 & 0.0 \\
\hline Ceanothus & 0.0 & 0.3 & 0.0 & 0.0 & 0.0 & 0.0 & 0.0 & 0.0 & 0.0 \\
\hline Krameria & 0.0 & 0.0 & 0.0 & 0.0 & 0.0 & 0.0 & 0.0 & 0.0 & 0.3 \\
\hline Ribes & 0.3 & 0.0 & 0.0 & 0.0 & 0.0 & 0.0 & 0.0 & 0.0 & 0.0 \\
\hline Platyopuntia & 0.3 & 0.0 & 0.0 & 0.6 & 0.3 & 0.6 & 18.3 & 4.2 & 1.9 \\
\hline Poaceae & 0.3 & 0.8 & 0.3 & 0.0 & 1.1 & 1.1 & 0.0 & 0.0 & 1.9 \\
\hline Boraginaceae & 1.4 & 1.9 & 0.8 & 0.0 & 1.4 & 1.9 & 1.1 & 0.0 & 0.0 \\
\hline Brassicaceae & 0.0 & 0.0 & 0.0 & 0.0 & 0.0 & 0.0 & 0.0 & 0.6 & 0.0 \\
\hline Fabaceae & 1.1 & 0.6 & 0.0 & 0.6 & 0.3 & 0.3 & 0.0 & 0.0 & 1.1 \\
\hline Eriogonum & 2.5 & 0.3 & 0.3 & 0.0 & 0.0 & 0.8 & 0.0 & 0.6 & 3.5 \\
\hline Leptodactylon & 2.5 & 4.7 & 0.3 & 1.7 & 0.8 & 0.3 & 0.9 & 0.3 & 0.5 \\
\hline Galium & 4.1 & 0.3 & 0.3 & 0.8 & 1.1 & 1.4 & 0.0 & 0.0 & 0.0 \\
\hline Lamiaceae & 0.3 & 1.1 & 0.0 & 0.3 & 0.0 & 0.6 & 0.6 & 0.0 & 0.5 \\
\hline Hydrophyllaceae & 0.0 & 0.6 & 0.0 & 0.0 & 0.0 & 0.0 & 1.4 & 0.0 & 0.0 \\
\hline Phacelia & 0.5 & 0.0 & 0.0 & 0.6 & 0.0 & 0.0 & 0.0 & 0.0 & 0.5 \\
\hline Mentzelia & 0.0 & 0.8 & 0.0 & 0.0 & 0.0 & 0.0 & 0.0 & 0.0 & 0.0 \\
\hline Caryophyllaceae & 0.5 & 0.6 & 0.0 & 0.0 & 0.6 & 0.6 & 0.0 & 0.0 & 0.0 \\
\hline Cirsium & 0.0 & 0.0 & 0.0 & 0.3 & 0.3 & 0.0 & 2.0 & 0.8 & 0.8 \\
\hline Senecio-type & 0.0 & 0.0 & 0.0 & 0.3 & 0.3 & 0.0 & 0.3 & 0.0 & 0.5 \\
\hline cf. Mimulus & 0.0 & 0.3 & 0.0 & 0.0 & 0.0 & 0.0 & 0.0 & 0.0 & 0.0 \\
\hline Astragalus-type & 0.0 & 0.0 & 0.0 & 0.0 & 0.0 & 0.0 & 4.6 & 1.9 & 0.0 \\
\hline Geraniaceae & 0.3 & 0.0 & 0.0 & 0.3 & 0.0 & 0.0 & 0.0 & 0.0 & 0.0 \\
\hline Plantago & 0.3 & 0.0 & 0.0 & 0.0 & 0.0 & 0.0 & 0.0 & 0.0 & 0.0 \\
\hline Polygonaceae/Chorizanthe & 1.6 & 0.0 & 0.6 & 0.3 & 0.0 & 0.0 & 0.0 & 0.0 & 0.0 \\
\hline
\end{tabular}


Table 6 (continued)

Sample: FMC 7(3) FMC 7(1) FMC 9A(1) FMC 11A(2) FMC 11A(1) FMC 11B FMC 10A(1) FMC 10C(2) FMC 12B

\begin{tabular}{lccccccccc} 
Approximate Age (yr B.P.) & $>52,000$ & $\mathbf{4 7 , 2 0 0}$ & $\mathbf{2 1 , 8 3 0}$ & $\mathbf{1 6 , 4 1 0}$ & $\mathbf{1 5 , 8 7 0}$ & $\mathbf{1 2 , 8 7 0}$ & $\mathbf{9 , 4 7 0}$ & $\mathbf{9 , 3 9 0}$ & 2,770 \\
\hline Hydrophile Pollen (HP) & & & & & & & & & \\
Abies & 0.0 & 0.0 & 0.0 & 0.0 & 0.3 & 0.0 & 0.0 & 0.0 & 0.0 \\
Rumex & 0.0 & 0.3 & 0.3 & 0.0 & 0.0 & 0.0 & 0.0 & 0.0 & 0.0 \\
Populus & 0.0 & 0.3 & 0.0 & 0.0 & 0.0 & 0.3 & 0.0 & 0.3 & 0.0 \\
Salix & 0.0 & 1.4 & 0.0 & 0.6 & 0.3 & 0.6 & 0.3 & 0.0 & 0.0 \\
Typha & 0.0 & 0.0 & 0.0 & 0.0 & 0.3 & 0.0 & 0.0 & 0.0 & 0.0 \\
Cyperaceae & 0.3 & 0.0 & 0.3 & 0.0 & 0.6 & 0.0 & 0.0 & 0.0 & 0.0 \\
I HP & 0.3 & 2.0 & 0.6 & 0.6 & 1.5 & 0.9 & 0.3 & 0.3 & 0.0 \\
\hline
\end{tabular}


Consistent with Thompson's (1990) finding that joint-fir did not invade Great Basin woodland until well into the Holocene, all the ancient midden samples from Fortymile Canyon contain negligible Ephedra pollen except the youngest, late Holocene assemblage (FMC-12B; Table 6). Like pinyon, joint-fir was likely near its northern limits in this area during the last glacial age. It is relatively common in glacial-age middens from xeric, lower-elevation sites in the Amargosa Desert, ca. $35 \mathrm{~km}$ to the south (Spaulding, 1990a). Also similar to the pinyon record here, joint-fir macrofossils occur in one of the older FMC-7 assemblages. In this case, however; it is unaccompanied by an appreciable amount of Ephedra pollen.

Lower percentages of Cheno-am, and generally higher percentages of Artemisia pollen distinguish the Wisconsin and early Holocene age pollen samples from the late Holocene and modern assemblages (Tables 5, 6). The early Holocene FMC-10 pollen samples have unusually high percentages of Platyopuntia (prickly-pear) pollen, consistent with the observation that the climate of this period favored the expansion of succulent species (Spaulding and Graumlich, 1986). The FMC-10 macrofossil assemblages also contain abundant prickly-pear spines. However, so do the FMC-9A, $-11 \mathrm{~A}(2)$, and $-11 \mathrm{~B}$ macrofossil assemblages (Table 2), although pollen samples from these midden strata yielded negligible Platyopuntia pollen (Table 6).

The pollen of hydrophilic plants (HP) is scarce in most of the ancient pollen samples, and the regular occurrence of one or two grains can be attributed to long-distance transport from expanded phreatic habitats in distant valley bottoms (e.g., Quade and Pratt, 1989). Two exceptions appear, however, the samples from FMC-7(1) and FMC$11 \mathrm{~A}(1)$ ( $\Sigma \mathrm{HP}=2 \%$ and $1.2 \%$, respectively) (Table 6). The former also yielded the macrofossils of hydrophilic plant species, including willow (Table 2) which, at 1.4\%, is the most common hydrophilic pollen type in the FMC-7(1) pollen sample (Table 6). The numbers of Salix, Typha, and Cyperaceae (sedge) pollen in FMC-11A(1) collectively appear to exceed that which might be expected based on long-distance transport alone, and they are not matched by any macrofossil records from that assemblage. Therefore, it is possible that this assemblage indicates the presence of perennial water in the bottom of Fortymile Canyon at ca. 15,900 yr B.P. 


\section{Riparian Environments of Fortymile Canyon}

Tables 7A and 7B present a list of those plant species that can be useful in . paleohydrologic reconstructions recovered as macrofossils from the Fortymile Canyon middens. They are placed in four categories, listed below, with abbreviations as used in the tables:

- The obligate hydrophiles, or phreatophytes $(\mathrm{H})$. These are species that are necessarily rooted in perennial water, such as willow, cottonwood (Populus sp.), and cat-tail (Typha sp.).

- The facultative phreatophytes (h). These are species restricted to springs and the banks of perennial streams in the Great Basin, but that occur over a broader range of habitats elsewhere in the western United States. Examples include wild rose and net-leaf hackberry. Also included in this category are plants often restricted to perennially moist habitats near their lower elevational limits, such as white fir.

- Plants associated with riparian habitats in the Nevada Test Site area by Beatley (1976) (aH). These are annual forbs such as dock and Scouler's heliotrope, collected in perennially moist habitats.

- Desert riparian plant species (DR). Riparian desert scrub is a distinctive community typical of ephemeral drainages (Bradely and Deacon, 1967), and there are plant taxa that are found almost exclusively in these communities. These are shrubs and forbs, such as prickly-poppy and arroyo bursage, well-adapted to habitats characterized by episodic floods and sandy, disturbed soils. They do not indicate the presence of perennial moisture.

Only two macrofossil assemblages from Fortymile Canyon provide unequivocal evidence of perennial water, those from the FMC-7 site. Four hydrophilic taxa and two desert-riparian species were encountered in FMC-7(1), and two hydrophilic species in FMC-7(3). Plants such as willow, wild rose, and marsh knotweed indicate perennial water within packrat foraging distance of the site. The remains of the desert-riparian species arroyo bursage (Table 7A) suggests that the canyon-bottom habitat was accessible from the FMC-7 site, and that the vegetation sampled by the packrat was 
Table 7A. Paleohydrologic Indicators From Fortymile Canyon Packrat Middens Dating ca. 15,900 to >52,000 B.P., and Near The Sites Today.

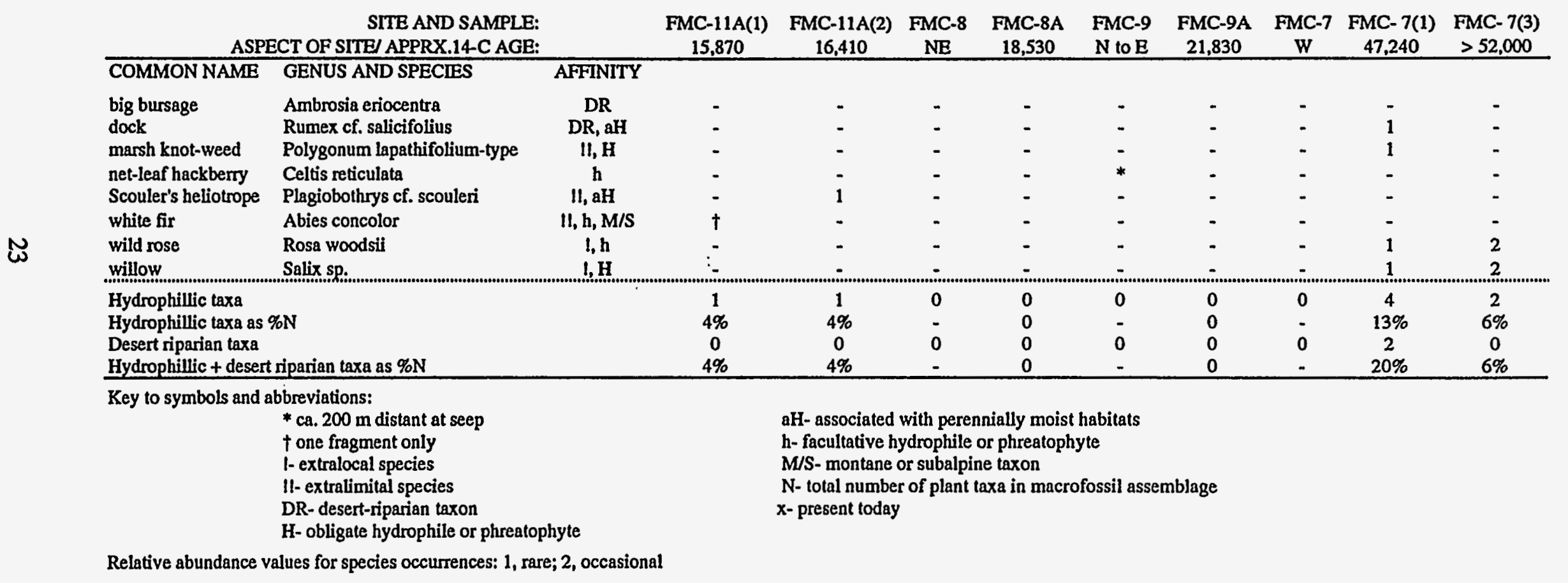


Table 7B. Paleohydrologic Indicators From Fortymile Canyon Packrat Midden Dating ca. 2,800 to 13,000 B.P., and Near The Sites Today.

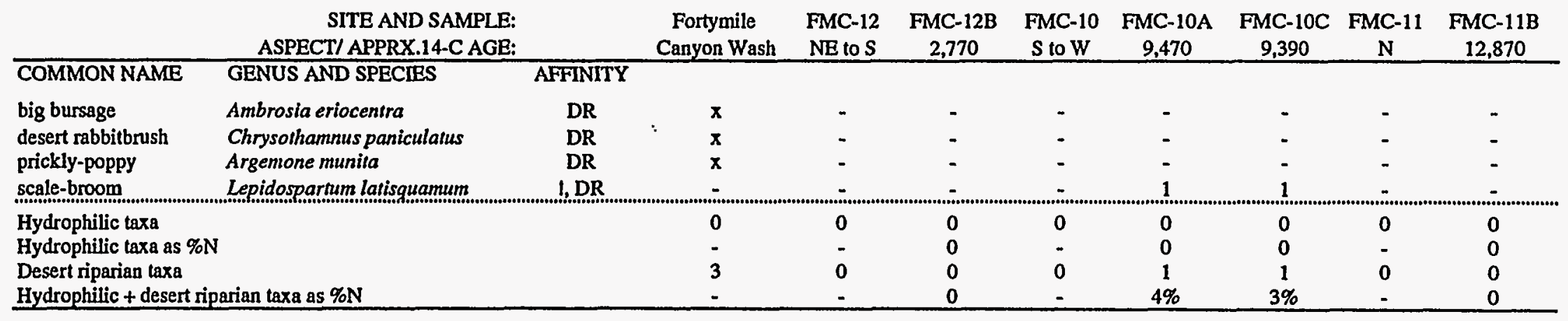


probably not that of a perennial seep on the canyon wall. This is consistent with the absence of of paleospring deposits in the vicinity of the site.

The marsh knot-weed (Polygonum lapathifolium-type) seeds recovered from the FMC$7(1)$ assemblage deserve special mention. Only one Polygonum species ( $P$. douglasii) is recorded as native to the Nevada Test Site area (Beatley, 1976), and its seeds are shaped differently from those of this fossil taxon. The knotweed seeds from FMC-7(1) are lenticular and without angles, a morphology conforming with taxa such as $P$. pennsylvanicum and $P$. lapathifolium. This taxonomic assignment is important to the hydrologic reconstruction of this site because $P$. douglasii may grow in mesic settings away from water, while those taxa included in $P$. lapathifolium-type occupy the moist, disturbed soils of wet meadows and stream-sides (Hickman, 1993; Munz, 1968). Like wild-rose and willow, it was likely growing below the site, on the margins of the channel of Fortymile Canyon.

The question of whether packrats were collecting plants from the bottom of Fortymile Canyon, or from a seep somewhere nearer the FMC-7 site, is an important one because the site is presently 80 to $100 \mathrm{~m}$ from the edge of Fortymile Wash, and more than $50 \mathrm{~m}$ above the canyon's floor (Figure 2). It appears likely that, at this time, there was more alluvium in Fortymile Canyon, elevating its bed and bringing the canyon-bottom habitat within $30 \mathrm{~m}$ of the site. In other words, it appears that the canyon was not as deeply incised during the Early to Middle Wisconsin. This would imply the scouring of the middle reaches of Fortymile Canyon during latest Quaternary times.

In contrast to the Fortymile Canyon-7 assemblages, those from other middens yield few macrofossils of riparian plants (Table 7A). A single white fir needle in FMC-11A(1) and the seeds of Scouler's heliotrope in FMC-11A(2) do not constitute unequivocal indicators of perennial water. However, when the $\mathrm{FMC}-11 \mathrm{~A}(1)$ pollen record, with its white fir, cat-tail, sedge, and willow grains is also considered (Table 6), then the possibility that perennially wet habitats existed elsewhere in the immediate vicinity needs to be seriously considered. Macrofossils of hydrophilic taxa have not been identified in the early Holocene FMC-10 assemblages (Table 7B), despite the proximity of this site to the margin of the Fortymile Canyon wash ( $<50 \mathrm{~m}$; Figure 2; Table 3). That packrats ventured into the wash from this site is demonstrated by the occurrence of the desertriparian shrub, scale-broom, in both FMC-10 assemblages (Table 7B). The absence of 
hydrophilic species from the FMC-10 assemblages therefore suggests the absence of perennial water in Fortymile Canyon during this part of the early Holocene (ca. 9,400 B.P.).

\section{SANDY VALLEY}

Sandy Valley, also known as Mesquite Valley, is a hydrographically closed basin lying between the southern Spring Range and the Mesquite Mountains to the east and west, respectively. Clark Mountain lies to the south, while a modest topographic high separates Sandy Valley from Pahrump Valley to the north. The midden sites are in northwestern Sandy Valley on an inselberg of Paleozoic carbonate rock named Black Butte, close to paleospring deposits at 885 and $935 \mathrm{~m}$ elevation (Figure 3; Table 8). The present vegetation of the area where the sites are located is typified by sparse desert scrub with the most common perennial species being white bursage, creosote bush, snakeweed, and brickell-bush (see Appendix II). Mesquite persists along the fault lineaments that mark the loci of past spring discharge (Quade et al., in press).

\section{Age of The Sandy Valley Midden Samples}

The bedrock in the vicinity of the Sandy Valley paleospring deposits contains abundant shelters and small caves that appear ideal for the preservation of ancient packrat middens. In the search for middens at this locality, emphasis was placed on collecting those deposits which appeared to be of the greatest age. However, despite the ideal setting and the scores of individual cavities that were checked, only two middens of any great antiquity were discovered. A large midden deposit, Sandy Valley- 2 (SaV-2), contained multiple units that were deposited in less than a millennium, from ca. 9400 to ca. 8800 yr B.P. A much smaller deposit from a separate shelter, SaV-3, also dates to the early Holocene (ca. 8500 and $9400 \mathrm{yr}$ B.P.) (Table 1). Due to the thoroughness of the field search and emphasis on the oldest assemblages recovered, the absence of glacial-age middens from this locality is not an artifact of sampling procedure. The reason for the absence of older middens from this locality is unknown. In Clark Mountain, less than $35 \mathrm{~km}$ to the south, early work recovered middens more than 20,000 years old (Mehringer and Ferguson, 1969). 


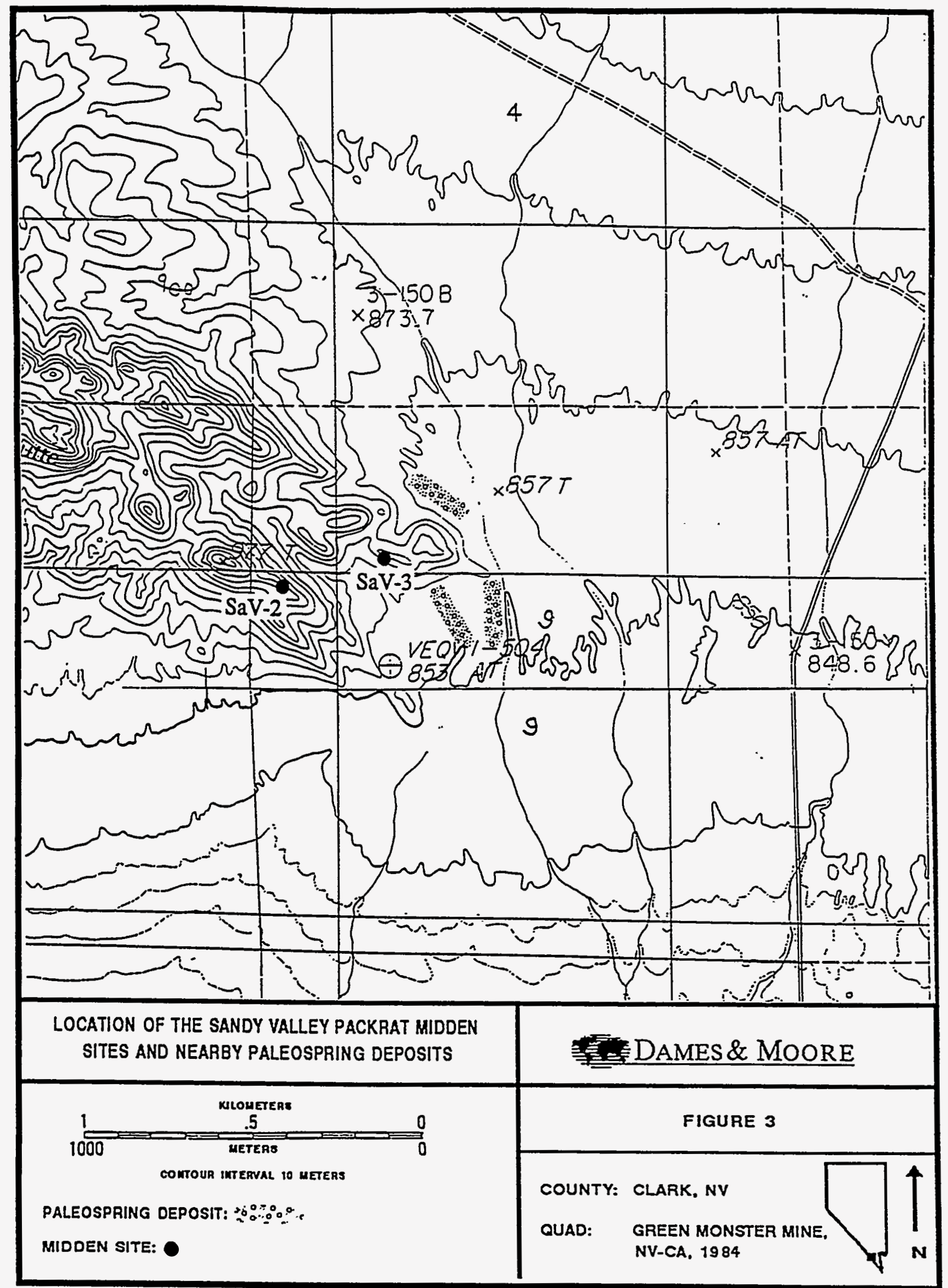


Table 8. Habitat Attributes of the Sandy valley and Double Canyon Packrat Midden Sites.

\begin{tabular}{|c|c|c|c|c|c|c|c|c|c|c|c|c|c|c|}
\hline \multirow[b]{2}{*}{ Site name and no. } & \multirow[b]{2}{*}{ N. lat. } & \multirow[b]{2}{*}{ W. long. } & \multirow[b]{2}{*}{ Elev. } & \multirow{2}{*}{$\begin{array}{l}\text { Distance } \\
\text { to target }\end{array}$} & \multirow{2}{*}{$\begin{array}{c}\text { Elev. above } \\
\text { target }\end{array}$} & \multicolumn{3}{|c|}{ Site's primary habitat } & \multicolumn{3}{|c|}{ Secondary habitat } & \multicolumn{3}{|c|}{ Tertiary habitat } \\
\hline & & & & & & Type & Aspect & Area & Type & Aspect & Area & Type & Aspect & Area \\
\hline $\begin{array}{l}\text { Sandy Valley-2 } \\
\text { Sandy. Valley-3 }\end{array}$ & $\begin{array}{l}35^{\circ} 52^{\prime} 40^{\prime \prime} \\
35^{\circ} 52^{\prime} 40^{\prime \prime}\end{array}$ & $\begin{array}{l}115^{\circ} 42^{\prime} 28^{n} \\
115^{\circ} 42^{\prime} 25^{\prime \prime}\end{array}$ & $\begin{array}{r}935 \\
885 \\
. .0 .0 .\end{array}$ & $\begin{array}{l}410 \\
170\end{array}$ & $\begin{array}{r}80 \\
30 \\
. .30\end{array}$ & 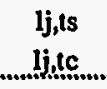 & $\begin{array}{c}45^{\circ} \\
230^{\circ}\end{array}$ & $\begin{array}{l}60 \% \\
50 \%\end{array}$ & $\begin{array}{c}\mathrm{tp} \\
\mathrm{rtp} . \mathrm{l}\end{array}$ & $135^{\circ}$ & $\begin{array}{l}15 \% \\
40 \%\end{array}$ & $\begin{array}{l}\text { stc } \\
\text { alf. }\end{array}$ & $\begin{array}{c}160^{\circ}-90^{\circ} \\
190^{\circ}\end{array}$ & $\begin{array}{l}25 \% \\
10 \%\end{array}$ \\
\hline $\begin{array}{l}\text { Double Canyon-1 } \\
\text { Double Canyon-4 }\end{array}$ & $\begin{array}{l}36^{\circ} 47^{\prime} 05^{\prime \prime} \\
36^{\circ} 46^{\prime} 50^{\prime \prime} \\
\end{array}$ & $\begin{array}{l}114^{\circ} 53^{\prime} 03^{\prime \prime} \\
114^{\circ} 52^{\prime} 53^{\prime \prime} \\
\end{array}$ & $\begin{array}{l}660 \\
690 \\
\end{array}$ & $\begin{array}{r}20 \\
180 \\
\end{array}$ & $\begin{array}{l}20 \\
40 \\
\end{array}$ & $\begin{array}{c}t s, l j, c l \\
1 \mathbf{j}\end{array}$ & $\begin{array}{r}40^{\circ}-65^{\circ} \\
95^{\circ}-120^{\circ} \\
\end{array}$ & $\begin{array}{l}80 \% \\
60 \% \\
\end{array}$ & $\begin{array}{c}c l_{1}, j, l c \\
\text { ste }\end{array}$ & $\begin{array}{r}45^{\circ}-90^{\circ} \\
80^{\circ}-105^{\circ} \\
\end{array}$ & $\begin{array}{l}20 \% \\
40 \% \\
\end{array}$ & $\begin{array}{c}\text { ws } \\
- \\
\end{array}$ & - & $\begin{array}{c}<1 \% \\
- \\
\end{array}$ \\
\hline
\end{tabular}

Abbreviations are: alf, alluvial fan; cl, cliff; flp, foodplain; lj, bedrock ledges; rtp, ridge top; stc, stabilized, colluvial slope; tc, rubbly talus chutes; ts, talus slopes; ws, dry wash.

All sites are on Paleozoic carbonate rock

Note that all elevations and distances are in meters, and based on calculations from $7.5^{\prime}$ topographic maps

"Target habitat" refers to the nearest paleospring deposits in Sandy Valley, and the channel of Coyote Springs Wash in Double Canyon 


\section{Early Holocene Paleoenvironments}

The macrofossil assemblages from the Sandy Valley middens reveal that mixed desert scrub occurred here between ca. 9,400 and 8,500 B.P. The absence of juniper is consistent with other records that indicate that, if there ever was woodland on these xeric, rocky slopes, it had been replaced by scrub vegetation well before the end of the early Holocene (Spaulding, 1983, 1990a; Wells and Woodcock, 1983). Ball-flower, box-thorn, Mormon-tea, native tobacco, and rock matchweed are the most common species in these assemblages (Table 9). These plants still occur near the midden sites although other shrubs, particularly creosote bush and white bursage, typify the modern vegetation.

Table 9. Selected plant species from the Sandy Valley packrat middens.

\begin{tabular}{|c|c|c|c|c|c|c|c|}
\hline & $\begin{array}{r}\text { SITE AND SAMPLE: SaV- } \\
\text { ASPECT/APPRX. 14-C AGE }\end{array}$ & & $\begin{array}{l}3(2) \\
9,430\end{array}$ & $\begin{array}{l}2(3) 3 \\
9,400\end{array}$ & $\begin{array}{l}2(3) 2 \\
9,250\end{array}$ & $\begin{array}{l}2(1) 1 \\
8,790\end{array}$ & $\begin{array}{c}3(1) \\
8,490\end{array}$ \\
\hline \multicolumn{8}{|c|}{ TREES, SHRUBS, AND SUCCULENTS } \\
\hline COMMON NAME & GENUS AND SPECIES & AFFINTTY & & & & & \\
\hline ball-flower & Buddleja utahensis & - & 3 & 2 & 2 & 3 & - \\
\hline blackbrush & Coleogyne ramosissima & $!$ & - & 1 & $\dagger$ & - & - \\
\hline box-thorn & Lycium sp. & - & 3 & 2 & 3 & 2 & 3 \\
\hline brickell-bush & Brickellia sp. & - & - & 2 & - & - & - \\
\hline brittle-bush & Encelia sp. & - & 1 & - & 1 & 1 & 1 \\
\hline cholla or prickly-pear & Opuntia sp. & $!$ & 1 & 1 & 1 & 1 & 1 \\
\hline cotton-top barrel cactus & Echinocactus polycephalus & - & & 1 & 1 & - & 1 \\
\hline creosote bush & Larrea divaricata & - & - & - & $\dagger$ & - & - \\
\hline four-wing saltbush & Atriplex canescens & 1 & - & 1 & - & - & - \\
\hline honey mesquite & Prosopis juliflora & !, H & - & - & - & - & 1 \\
\hline Joshua-tree & Yucca brevifolia & - & - & 1 & $\therefore$ & - & 1 \\
\hline yucca & Yucca sp. & - & - & - & 1 & - & - \\
\hline Mojave pepperweed & Lepidium cf. fremontii & $!$ & - & 1 & 2 & - & - \\
\hline Mormon-tea & Ephedra nevadensis-type & - & 2 & - & 1 & - & - \\
\hline Mormon-tea & Ephedra sp. & - & - & 2 & 3 & 3 & 1 \\
\hline native tobacco & Nicotiana trigonophylla & - & 2 & - & 2 & 1 & 2 \\
\hline netleaf hackberry & Celtis reticulata & $11, \mathrm{~h}$ & - & $t$ & - & - & - \\
\hline pepperweed & Lepidium montanum-type & - & 2 & - & 1 & 1 & 3 \\
\hline rubber rabbitbrush & Cbrysothamnus nauseosus & $!$ & 1 & 3 & 1 & - & - \\
\hline saltbush & Atriplex sp. & - & - & - & 1 & - & - \\
\hline shadscale & Atriplex confertifolia-type & - & 4 & - & - & 1 & - \\
\hline snake-weed & Gutierrezia microcephala & - & 2 & 1 & - & - & - \\
\hline
\end{tabular}


Table 9 (continued)

\begin{tabular}{|c|c|c|c|c|c|c|c|}
\hline & $\begin{array}{l}\text { SITE AND SAMPLE: SaV- } \\
\text { ASPECT/APPRX. 14C AGE }\end{array}$ & & $\begin{array}{l}3(2) \\
9,430\end{array}$ & $\begin{array}{l}2(3) 3 \\
9,400\end{array}$ & $\begin{array}{l}2(3) 2 \\
9,250\end{array}$ & $\begin{array}{l}2(1) 1 \\
8,790\end{array}$ & $\begin{array}{l}3(1) \\
8,490\end{array}$ \\
\hline snowberry & Symphoricarpos cf. longiflorus & !! & 3 & - & 1 & - & - \\
\hline snowberry & Symphoricarpos sp. & !! & - & - & - & 1 & - \\
\hline turpentine broom & Thamnosma montana & - & 1 & 1 & 1 & 2 & 1 \\
\hline white bursage & Ambrosia dumosa & - & - & - & 1 & $t$ & - \\
\hline winter-fat & Ceratoides lanata & $!$ & 1 & - & 1 & - & - \\
\hline HERBS, FORBS, AND & GRASSES & & & & & & \\
\hline desert plantain & Plantago sp. & - & 1 & - & 1 & 2 & 1 \\
\hline grasses & Poaceae undetermined & - & 3 & 1 & 1 & 1 & 2 \\
\hline prickly phlox & Leptodactylon pungens & - & - & 2 & 1 & - & - \\
\hline rockwort & Scopulophila rixfordii & - & - & 4 & 4 & 5 & - \\
\hline
\end{tabular}

Evidently creosote bush did not arrive in the region until after 8,200 B.P. (Spaulding, 1990b). White bursage (Ambrosia dumosa), on the other hand, is common in samples as old as ca. 8,800 B.P. from the Skeleton Hills to the north (Spaulding, 1990b), and occurs in middens as old as ca. 10,000 B.P. in Death Valley to the northwest (Wells and Woodcock, 1985). Its absence from the early Holocene Sandy Valley assemblages (Table 9) could be taken to indicate that its immigration into this isolated valley may have lagged behind its arrival in the larger desert valleys that have low-elevation passes opening to the south, the presumed direction of its glacial-age refugium. However, the substantial increase in Ambrosia pollen in the youngest midden sample (Table 10) indicates that white bursage may have entered Sandy Valley by this time (ca. $8,500 \mathrm{yr}$ B.P.), but did not colonize these rocky outcrops until later.

\section{The Pollen Data From Sandy Valley}

In contrast to the Fortymile Canyon packrat middens, arboreal pollen (AP) is not more abundant in the ancient middens from Sandy Valley, relative the modern samples. Indeed, $\Sigma \mathrm{AP}$ in the control samples is 7.1 and $7.8 \%$, while $\Sigma \mathrm{AP}$ in the five early Holocene pollen assemblages ranges from 1.3 to $6.8 \%$ (3.6\% $\pm 2.3 \%$ at $1 \sigma)$. Perhaps most interesting is the fact that the lowest AP percentages are found in the oldest 
samples, ranging in age from 9,250 to $9,430 \mathrm{yr}$ B.P. (Table 10). Although the paucity of AP in the early Holocene Sandy Valley assemblages could be considered unusual, it is consistent with the widespread retreat of woodland from these low-elevation Mojave Desert settings by at least 10,500 yr B.P. (Spaulding, 1983, 1990a).

Cheno-am pollen frequencies are not as high in these samples as one might expect at this low-elevation locality, although the lower values of Artemisia, relative to the Fortymile Canyon samples, is consistent with the more xeric setting of this locality. An exception to this generalization is the pollen assemblage from the SaV-2(1) midden stratum, dated at ca. 8,800 yr B.P. This assemblage contains $15.6 \%$ Artemisia pollen, in contrast to $\leq 3.1 \%$ in all other samples from the Sandy Valley locality, and it also contains the highest AP frequencies of all fossil samples analyzed here (6.2\%; Table 10). It is possible that this midden assemblage was deposited during a relatively brief, early Holocene pluvial event that has been dated elsewhere in the Mojave Desert at ca. 8,900 B.P. (Spaulding, 1990a, p. 169, 195).

There is a paucity of phreatophyte pollen in all the Sandy Valley pollen assemblages, with the exception of SaV-3(1), which contains 1.7\% Prosopis (mesquite) pollen. Mesquite is an insect-pollinated tree with pollen that does not disperse far. Therefore, this pollen record confirms the inference, based on the macrofossils of honey mesquite from this assemblage (Table 9), that it was growing locally at this time.

\section{Riparian Environments of Northern Sandy Valley}

In opposition to the middens of early Holocene age from Fortymile Canyon, those from Sandy Valley did yield the remains of phreatophytic plants, two species that are both obligate hydrophiles in the Mojave and Great Basin Deserts. Honey mesquite (Prosopis juliflora) pod fragments, leaflets, and pollen occur in the youngest assemblage (ca. 8,500 B.P.), while a single net-leaf hackberry seed occurs in the assemblage dated at 9,400 B.P. (Table 9). The presence of mesquite leaflets, pod fragments, and pollen (Table 10) indicate that the species was probably growing within $30 \mathrm{~m}$ of the site.

In the Mojave Desert today, mesquite occurs only on perennially moist ground, or in dunes along fault lineaments where it likely is reliant on perennial, subsurface water (Quade et al., in press). The SaV-3 midden site is presently ca. $180 \mathrm{~m}$ from the nearest 
Table 10. The Pollen Data the Sandy Valley and Double Canyon Packrat Midden Samples.

\begin{tabular}{|c|c|c|c|c|c|c|c|c|c|c|}
\hline $\begin{array}{r}\text { Sample: } \\
\text { Approximate 14-C Age } \\
\end{array}$ & $\begin{array}{c}\text { SaV 3(2) } \\
9,430 \\
\end{array}$ & $\begin{array}{c}\text { SaV 2(3)3 } \\
9,400 \\
\end{array}$ & $\begin{array}{c}\mathrm{SaV} 2(3) 2 \\
9,250 \\
\end{array}$ & $\begin{array}{l}\text { SaV 2(1) } \\
8,790 \\
\end{array}$ & $\begin{array}{c}\mathrm{SaV} 3(1) \\
8,490 \\
\end{array}$ & $\begin{array}{l}\text { SaV } 3.1 \\
\text { Modern }\end{array}$ & $\begin{array}{l}\text { SaV } 2.1 \\
\text { Modern }\end{array}$ & $\begin{array}{l}\text { DC } 1(1) \\
12,060 \\
\end{array}$ & $\begin{array}{l}\text { DC } 1.2 \\
\text { Modern }\end{array}$ & $\begin{array}{l}\text { DC 3.1 } \\
\text { Modern }\end{array}$ \\
\hline Pollen Sum & 384 & 390 & 351 & 378 & 358 & 388 & 399 & 353 & 356 & 359 \\
\hline Sample Concentration & 37,978 & 23,297 & 74,039 & 28,272 & 18,589 & 402,923 & $1,539,000$ & 5,721 & 137,314 & 969,300 \\
\hline Taxa Richness & 22 & 22 & 24 & 29 & 25 & 29 & 24 & 14 & 34 & 31 \\
\hline Tracers & 273 & 452 & 128 & 361 & 520 & 26 & 7 & 1666 & 70 & 10 \\
\hline Deteriorated & 5.7 & 3.1 & 2.3 & 6.9 & 3.9 & 3.6 & 5.0 & 3.7 & 5.1 & 3.1 \\
\hline Unknown & 0.8 & 0.8 & 0.0 & 1.3 & 0.6 & 1.8 & 1.0 & 0.3 & 0.3 & 2.8 \\
\hline Arboreal Pollen (AP) & & & & & & & & & & \\
\hline Pinus Haploxylon & 0.0 & 0.0 & 0.3 & 0.0 & 0.0 & 0.0 & 0.0 & 0.0 & 0.0 & 0.0 \\
\hline Pinus Diploxylon & 0.0 & 0.0 & 0.6 & 0.0 & 0.8 & 0.5 & 0.5 & 0.0 & 0.0 & 0.0 \\
\hline Pinus undifferentiated & 1.3 & 0.5 & 0.6 & 2.4 & 0.3 & 1.8 & 0.8 & 0.3 & 2.8 & 1.9 \\
\hline Pinus pinyon-type & 0.0 & 0.3 & 1.4 & 1.9 & 2.0 & 2.3 & 1.8 & 0.8 & 0.6 & 1.9 \\
\hline Juniperus & 0.0 & 0.5 & 0.3 & 1.6 & 0.6 & 1.8 & 3.5 & 69.4 & 2.5 & 5.6 \\
\hline Quercus & 0.0 & 0.0 & 0.6 & 0.0 & 0.0 & 0.8 & 0.0 & 0.0 & 0.0 & 0.3 \\
\hline Prosopis & 0.0 & 0.0 & 0.0 & 0.0 & 1.7 & 0.0 & 0.0 & 0.0 & 0.0 & 0.0 \\
\hline Cercidium & 0.0 & 0.0 & 0.0 & 0.0 & 0.0 & 0.3 & 0.0 & 0.0 & 0.0 & 0.0 \\
\hline Ulmus & 0.0 & 0.0 & 0.0 & 0.0 & 0.0 & 0.3 & 0.0 & 0.0 & 0.0 & 0.3 \\
\hline cf. Eucalyptus & 0.0 & 0.0 & 0.0 & 0.0 & 0.0 & 0.0 & 0.3 & 0.0 & 0.0 & 0.0 \\
\hline Fraxinus & 0.0 & 0.0 & 0.0 & 0.0 & 0.0 & 0.0 & 0.3 & 0.0 & 0.0 & 0.0 \\
\hline$\Sigma$ AP & 1.3 & 1.3 & 3.8 & 6.2 & 5.4 & 7.8 & 7.2 & 70.8 & 5.9 & 10.6 \\
\hline Ephedra nevadensis-type & 0.5 & 0.5 & 0.6 & 1.9 & 1.1 & 0.5 & 4.3 & 0.3 & 1.7 & 0.6 \\
\hline Ephedra other & 0.5 & 0.3 & 0.3 & 0.3 & 0.3 & 1.5 & 0.0 & 0.0 & 1.4 & 0.0 \\
\hline Sarcobatus & 0.0 & 0.3 & 0.0 & 0.0 & 0.0 & 0.0 & 0.0 & 0.0 & 0.0 & 0.0 \\
\hline Cheno-Am & 4.2 & 2.8 & 6.6 & 14.0 & 8.4 & 10.3 & 17.0 & 1.4 & 6.5 & 4.2 \\
\hline Artemisia & 1.0 & 3.1 & 3.1 & 15.6 & 2.2 & 1.8 & 2.5 & 5.1 & 2.2 & 1.1 \\
\hline Asteraceae Hi-Spine & 29.9 & 6.7 & 6.3 & 22.8 & 12.6 & 12.9 & 12.8 & 9.9 & 19.1 & 19.5 \\
\hline Ambrosia & 3.9 & 5.1 & 12.3 & 9.8 & 20.1 & 37.1 & 28.6 & 2.3 & 25.0 & 26.2 \\
\hline Sphaeralcea & 0.0 & 0.0 & 0.0 & 0.0 & 0.0 & 0.0 & 0.0 & 0.0 & 7.0 & 1.7 \\
\hline Rosaceae & 0.3 & 0.0 & 1.4 & 1.1 & 1.1 & 4.1 & 2.3 & 0.3 & 0.8 & 0.6 \\
\hline Pronus & 0.0 & 0.0 & 0.0 & 0.0 & 0.0 & 0.0 & 0.0 & 0.0 & 0.3 & 0.0 \\
\hline
\end{tabular}


Table 10 (continued)

\begin{tabular}{|c|c|c|c|c|c|c|c|c|c|c|}
\hline $\begin{array}{r}\text { Sample: } \\
\text { Approximate 14-C Age } \\
\end{array}$ & $\begin{array}{c}\mathrm{SaV} 3(2) \\
9,430 \\
\end{array}$ & $\begin{array}{c}\mathrm{SaV} 2(3) 3 \\
9,400 \\
\end{array}$ & $\begin{array}{c}\text { SaV } 2(3) 2 \\
9,250 \\
\end{array}$ & $\begin{array}{c}\mathrm{SaV} 2(1) \\
8,790 \\
\end{array}$ & $\begin{array}{c}\mathrm{SaV} 3(1) \\
8.490 \\
\end{array}$ & $\begin{array}{l}\text { SaV } 3.1 \\
\text { Modern }\end{array}$ & $\begin{array}{l}\text { SaV } 2.1 \\
\text { Modern }\end{array}$ & $\begin{array}{l}\text { DC } 1(1) \\
12,060 \\
\end{array}$ & $\begin{array}{l}\text { DC } 1.2 \\
\text { Modern } \\
\end{array}$ & $\begin{array}{l}\text { DC 3.1 } \\
\text { Modern }\end{array}$ \\
\hline Ceanothus & 0.0 & 0.0 & 0.0 & 0.0 & 0.0 & 0.0 & 0.0 & 0.0 & 0.3 & 0.0 \\
\hline Larrea & 0.0 & 0.0 & 0.0 & 0.0 & 0.0 & 4.9 & 3.5 & 0.0 & 7.3 & 5.3 \\
\hline Lycium & 1.3 & 0.3 & 0.6 & 1.1 & 0.3 & 0.0 & 0.8 & 0.0 & 0.6 & 0.6 \\
\hline Symphoricarpos & 0.3 & 0.3 & 0.0 & 2.1 & 0.0 & 0.0 & 0.0 & 0.0 & 0.3 & 0.0 \\
\hline Scopulophila & 29.7 & 15.1 & 0.0 & 2.1 & 13.4 & 0.3 & 6.0 & 0.0 & 0.0 & 0.3 \\
\hline Krameria & 0.0 & 0.0 & 0.3 & 0.0 & 0.0 & 0.5 & 0.0 & 0.0 & 0.3 & 0.3 \\
\hline Thamnosma & 0.3 & 0.0 & 0.0 & 0.0 & 0.0 & 0.0 & 0.0 & 0.0 & 0.3 & 2.5 \\
\hline Platyopuntia & 1.0 & 0.0 & 1.4 & 1.1 & 0.0 & 0.0 & 0.0 & 0.0 & 1.1 & 0.0 \\
\hline Mammilaria-type & 0.3 & 0.3 & 0.3 & 0.8 & 1.7 & 0.0 & 0.0 & 0.0 & 0.0 & 0.0 \\
\hline Ferocactus-type & 0.0 & 0.0 & 0.0 & 0.0 & 0.0 & 0.0 & 0.0 & 0.0 & 1.4 & 0.3 \\
\hline Poaceae & 2.3 & 1.3 & 6.0 & 2.9 & 1.4 & 1.5 & 1.0 & 0.8 & 2.0 & 2.2 \\
\hline Buddleja & 2.6 & 4.1 & 48.4 & 5.3 & 16.8 & 0.0 & 0.5 & 0.0 & 0.0 & 0.0 \\
\hline Boraginaceae & 0.0 & 0.5 & 0.0 & 0.5 & 1.1 & 0.3 & 0.0 & 0.3 & 0.6 & 2.2 \\
\hline Brassicaceae & 9.9 & 52.6 & 0.0 & 0.0 & 2.8 & 1.0 & 0.8 & 0.3 & 2.0 & 0.8 \\
\hline Fabaceae & 0.0 & 0.0 & 0.0 & 0.0 & 0.0 & 0.3 & 0.3 & 0.0 & 0.0 & 0.3 \\
\hline Eriogonum & 0.8 & 0.3 & 1.1 & 0.5 & 1.4 & 2.1 & 2.0 & 0.0 & 3.9 & 6.4 \\
\hline Gilia & 0.0 & 0.0 & 0.3 & 0.3 & 0.0 & 0.0 & 0.3 & 0.0 & 0.3 & 0.6 \\
\hline Leptodactylon & 1.3 & 0.3 & 0.0 & 0.3 & 0.6 & 0.5 & 1.8 & 0.0 & 0.0 & 0.0 \\
\hline Polemonium & 0.0 & 0.0 & 0.0 & 0.5 & 0.0 & 0.0 & 0.0 & 0.0 & 0.3 & 0.0 \\
\hline Gallum & 0.0 & 0.3 & 0.0 & 0.0 & 0.0 & 0.0 & 0.0 & 0.0 & 0.3 & 0.0 \\
\hline Lamiaceae & 0.3 & 0.0 & 0.0 & 0.0 & 0.0 & 0.0 & 0.0 & 4.5 & 0.0 & 0.0 \\
\hline Plantago & 0.0 & 0.0 & 0.0 & 0.0 & 0.0 & 0.0 & 0.0 & 0.0 & 0.6 & 0.3 \\
\hline Chorizanthe & 1.6 & 1.0 & 4.3 & 1.1 & 3.6 & 3.9 & 2.5 & 0.0 & 1.1 & 4.2 \\
\hline Cirsium & 0.0 & 0.0 & 0.0 & 0.5 & 0.0 & 0.0 & 0.0 & 0.0 & 0.0 & 0.8 \\
\hline Senecio-type & 0.0 & 0.0 & 0.0 & 0.0 & 0.0 & 0.5 & 0.0 & 0.0 & 0.0 & 0.0 \\
\hline cf. Euphorbia & 0.0 & 0.0 & 0.6 & 0.5 & 0.3 & 0.3 & 0.0 & 0.0 & 0.0 & 0.0 \\
\hline Solanaceae & 0.3 & 0.0 & 0.3 & 0.3 & 0.6 & 0.0 & 0.0 & 0.0 & 0.3 & 0.0 \\
\hline cf. Physalis & 0.0 & 0.0 & 0.0 & 0.0 & 0.0 & 0.8 & 0.0 & 0.0 & 0.0 & 0.0 \\
\hline Boerhaavia-type & 0.0 & 0.0 & 0.0 & 0.3 & 0.0 & 0.0 & 0.0 & 0.0 & 0.3 & 0.3 \\
\hline
\end{tabular}


Table 10 (continued)

\begin{tabular}{|c|c|c|c|c|c|c|c|c|c|c|}
\hline $\begin{array}{r}\text { Sample: } \\
\text { Approximate 14-C Age } \\
\end{array}$ & $\begin{array}{c}\text { SaV 3(2) } \\
9.430 \\
\end{array}$ & $\begin{array}{c}\mathrm{SaV} 2(3) 3 \\
9,400 \\
\end{array}$ & $\begin{array}{c}\text { SaV 2(3)2 } \\
9,250 \\
\end{array}$ & $\begin{array}{c}\text { SaV 2(1) } \\
8,790 \\
\end{array}$ & $\begin{array}{c}\text { SaV } 3(1) \\
8.490\end{array}$ & $\begin{array}{l}\text { SaV } 3.1 \\
\text { Modern }\end{array}$ & $\begin{array}{l}\text { SaV } 2.1 \\
\text { Modern }\end{array}$ & $\begin{array}{l}\text { DC } 1(1) \\
12,060\end{array}$ & $\begin{array}{l}\text { DC } 1.2 \\
\text { Modern }\end{array}$ & $\begin{array}{l}\text { DC } 3.1 \\
\text { Modern } \\
\end{array}$ \\
\hline Eucnide & 0.0 & 0.0 & 0.0 & 0.0 & 0.6 & 0.5 & 0.0 & 0.0 & 0.0 & 0.0 \\
\hline Onagraceae & 0.0 & 0.0 & 0.0 & 0.0 & 0.0 & 0.0 & 0.3 & 0.0 & 1.1 & 1.4 \\
\hline Liguliflorae & 0.0 & 0.0 & 0.0 & 0.0 & 0.0 & 1.3 & 0.0 & 0.0 & 0.3 & 1.4 \\
\hline Tidestroemia & 0.0 & 0.0 & 0.0 & 0.0 & 0.0 & 0.0 & 0.0 & 0.0 & 0.3 & 0.3 \\
\hline Quercus & 0.0 & 0.0 & 0.6 & 0.0 & 0.0 & 0.8 & $\overline{0.0}$ & 0.0 & $\overline{0.0}$ & 0.3 \\
\hline Alnus & 0.0 & 0.0 & 0.0 & 0.3 & 0.0 & 0.0 & 0.0 & 0.3 & 0.0 & 0.0 \\
\hline Prosopis & 0.0 & 0.0 & 0.0 & 0.0 & 1.7 & 0.0 & 0.0 & 0.0 & 0.0 & 0.0 \\
\hline Celtis & 0.0 & 0.0 & 0.0 & 0.0 & 0.0 & 0.0 & 0.0 & 0.0 & 0.0 & 0.0 \\
\hline Ulmus & 0.0 & 0.0 & 0.0 & 0.0 & $0.0^{\circ}$ & 0.3 & 0.0 & 0.0 & 0.0 & 0.3 \\
\hline$\sum$ Hydrophile Pollen & 0.0 & 0.0 & 0.6 & 0.3 & 1.7 & 1.1 & 0.0 & 0.3 & 0.0 & 0.6 \\
\hline
\end{tabular}


outcrop of paleospring sediments, and ca. $30 \mathrm{~m}$ above those deposits (Figure 3). The mesquite macrofossils from SaV-3 indicate that, during at least this part of the early Holocene, mesquite was closer to the midden site than it is at present. Given a relative rise of the water table of 10 to $20 \mathrm{~m}$ during the Late Wisconsin and early Holocene(Unit E time; Quade et al., in press) mesquite, with its capability to develop long root systems (Kearney and Peebles, 1969), would have been able to grow on the rocks near the midden site and extend its roots to this elevated water table (Figure 3). Mesquite's absence from oldest middens may be more likely due to postglacial migrational lag than to the absence of phreatic environments here. Prosopis is a subtropical genus that, like many other thermophilous species (Spaulding, 1990b), was absent from this region during the last glacial age. The dates from the Sandy Valley middens suggest that it arrived here between ca. 8,800 and 8,500 B.P.

In this region the remains of net-leaf hackberry (Celtis reticulata), such as the seed recovered from the SaV-2(3) assemblage, occur exclusively in early Holocene packrat middens (Table 11). The tree is an obligate phreatophyte throughout its range in the Great Basin and adjacent areas (Benson and Darrow, 1981). Even in the Grand Canyon, which receives more average annual and summer precipitation than does the Yucca Mountain area, net-leaf hackberry is restricted to perennially moist sites (Phillips et al., 1987). Because only one seed was found in Sav-2(3), and no pollen of the species was encountered in the pollen analyses, the seed's presence is likely due to long-distance transport. Hackberry seeds are attractive to animals, and it was probably transported to the site in the gut of a bird or mammal. Packrats commonly incorporate feces and raptor casts into their middens, and this is the presumed manner of origin of all these net-leaf hackberry fossil records, with the exception one site in the Sheep Range (Table 11).

\section{DOUBLE CANYON}

Double Canyon channels Pahranagat Wash through part of its course from the Coyote Springs Valley to the west, to the Moapa Valley to the east. Pahranagat Wash has a very large drainage basin extending well into Lincoln County and encompassing the perennial Paharanagat Lakes. However, it is an ephemeral drainage along this portion of its reach. Hydrophilic species that now can be found in Double Canyon are mesquite, desert willow (Chilopsis linearis), and catclaw acacia (Acacia greggii), the former two 


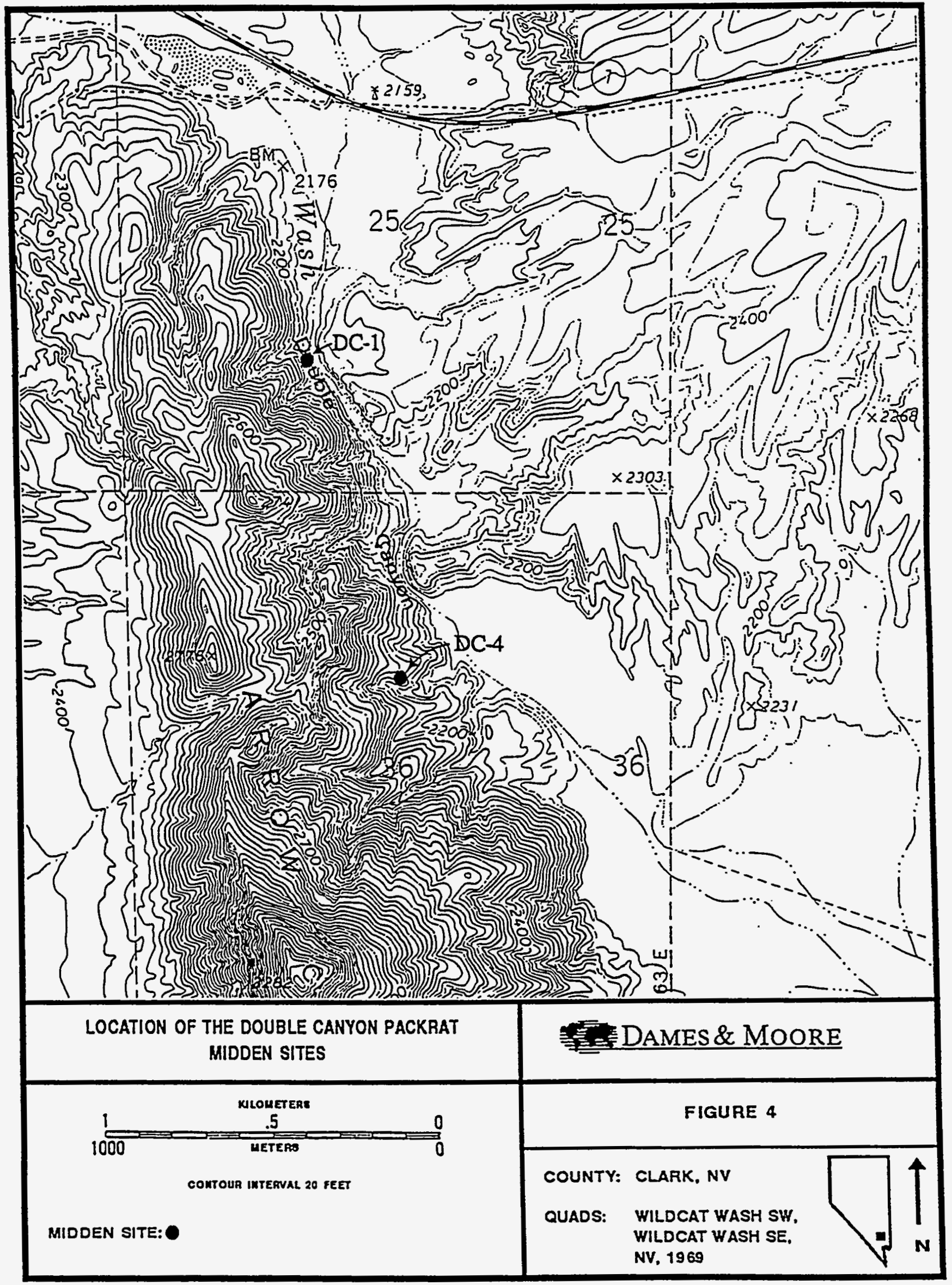


Table 11. Early Holocene and Wisconsin Age Macrofossil Records of Hydrophilic Species from Southern Nevada

\begin{tabular}{|c|c|c|c|c|c|c|c|c|}
\hline Area \& Site & N. lat. & W. long. & $\begin{array}{l}\text { Elev. } \\
\text { (m) }\end{array}$ & $\begin{array}{c}\text { Sample no. } \\
\text { or Unit }\end{array}$ & Specles & Source & $\begin{array}{l}\text { 14.C date } \\
\text { (yx B.P.) }\end{array}$ & $\begin{array}{c}\text { Laboratory no. } \\
\text { (reference) }\end{array}$ \\
\hline $\begin{array}{l}\text { Amargosa Desert } \\
\text { Skeleton Hills-1 } \\
\text { Sketelion Hills-2 }\end{array}$ & $\begin{array}{l}36^{\circ} 32^{\prime} \\
36^{\circ} 38^{\circ}\end{array}$ & $\begin{array}{l}116^{\circ} 20^{\prime} \\
116^{\circ} 17^{\prime}\end{array}$ & $\begin{array}{r}910 \\
940\end{array}$ & $\begin{array}{l}\text { Sk-1B(2) } \\
\text { S Sk-2(2) }\end{array}$ & $\begin{array}{c}\text { Celtis reticulata } \\
\text { _Ondatra zibethicus**_ }\end{array}$ & $\begin{array}{l}\text { long-distance } \\
\text { long-distance }\end{array}$ & $\begin{array}{r}9,200 \pm 140 \\
-8,170 \pm 100\end{array}$ & $\begin{array}{l}\text { B-7264 (t.r.) } \\
\text { B-9168 (t.r.). }\end{array}$ \\
\hline $\begin{array}{l}\text { Sheep Range } \\
\text { Willow Wash-4 } \\
\text { Flaherty Shelter } \\
\text { Deadman-2 }\end{array}$ & $\begin{array}{l}36^{\circ} 28^{\prime} \\
36^{\circ} 30^{\circ} \\
36^{\circ} 37^{\prime}\end{array}$ & $\begin{array}{l}115^{\circ} 15^{\prime} \\
115^{\circ} 14^{\prime} \\
115^{\circ} 16^{\prime}\end{array}$ & $\begin{array}{l}1585 \\
1650 \\
2075\end{array}$ & $\begin{array}{l}\text { WW-4B } \\
\text { Unit 3, } 125 \mathrm{~cm} \\
\text { Dm-2 }\end{array}$ & $\begin{array}{l}\text { Populus sp. } \\
\text { Celis reticulata } \\
\text { Cellis reticulata }\end{array}$ & $\begin{array}{c}\text { local (?) } \\
\text { long-distance } \\
\text { local }\end{array}$ & $\begin{array}{c}9,820 \pm 110 \\
* \\
9,560 \pm 180\end{array}$ & $\begin{array}{c}\text { WSU-1861 (1.r.) } \\
\text { (Spaulding, 1974) } \\
\text { A-1730 (Spaulding, 1981) }\end{array}$ \\
\hline $\begin{array}{l}\text { Littlo Skall Mountain } \\
\text { LSM151 182LP1 }\end{array}$ & . n.g. & & 1173 & $-(3,2)$ & _ _ Cellis reticulatata & long-_istanc & $-9.480 \pm 370$ & \\
\hline $\begin{array}{l}\text { North Yucca Moumtain } \\
\text { Portymilo Canyon-7 }\end{array}$ & $36^{\circ} 57^{\circ}$ & $116^{\circ} 22^{\prime}$ & 1250 & FMC-7(1) & $\begin{array}{l}\text { Salix sp., Rosa woodsii } \\
\text { Polygonum lapathifolium-type }\end{array}$ & local & $47,200 \pm 3000$ & QL-4218 (t.r.) \\
\hline $\begin{array}{l}\text { Sandy Valley } \\
\text { Sandy Valley- } 2 \\
\text { Sandy Yalloy-3. }\end{array}$ & $\begin{array}{l}35^{\circ} 53^{\prime \prime} \\
35^{\circ} 53^{\prime}\end{array}$ & $\begin{array}{l}115^{\circ} 42^{\prime} \\
-115^{\circ}-42^{\prime}\end{array}$ & $\begin{array}{r}935 \\
885 \\
-\end{array}$ & $\begin{array}{l}\text { SaV-2(3)3 } \\
\text { SaV-3(1) }\end{array}$ & $\begin{array}{l}\text { Celtis reticulata } \\
\text { Prosopis julifiora }\end{array}$ & $\begin{array}{l}\text { long-distance } \\
\text { - } \text { local _-_ }\end{array}$ & $\begin{array}{r}9,400 \pm 90 \\
-8,500 \pm 120\end{array}$ & $\begin{array}{l}\text { QL-4227(1.r.) } \\
\text { QL-4236(1.r. })\end{array}$ \\
\hline $\begin{array}{l}\text { Moapa Valley } \\
\text { Yalley fill near Overt }\end{array}$ & $36^{\circ} 35^{\prime}$ & $.114^{\circ} 30^{\prime}$ & 400 & & Prosopis julifiora & & $-8.080 \pm 40$ & \\
\hline $\begin{array}{l}\text { Las Vegas Valley } \\
\text { Tulo Springs }\end{array}$ & $36^{\circ} 18^{\prime}$ & $115^{\circ} 16^{\prime}$ & 710 & $\begin{array}{l}\text { Unit E1 } \\
\text { Unit E2 } \\
\text { Unit D }\end{array}$ & $\begin{array}{l}\text { Fraxinus sp. } \\
\text { Populus sp., Fraxinus sp. } \\
\text { Fraxinus sp., Quercus sp. }\end{array}$ & $\begin{array}{l}\text { local } \\
\text { local } \\
\text { local }\end{array}$ & $\begin{array}{c}13,500-11,500 \\
11,000-7500 \\
\text { ca. } 27,000\end{array}$ & $\begin{array}{c}\text { (Mehringer, 1965) } \\
\text { (Mehringer, 1965) } \\
\text { (McVickar and Spaulding, 1993) }\end{array}$ \\
\hline
\end{tabular}

- sample from bioturbated cave sediment, $75 \mathrm{~cm}$ below a radiocarbon date of 6,950 \pm 320 B.P. (A-1297).

** record is of a hydrophilic mammal, all others arc of phreatophytic plants. This species is now extinct in southern Nevada.

$\dagger$ sample is from gravels at a depth of 20 to $30 \mathrm{~m}$ below the bottom of the Moapa River Valley; n.g., not given; t.r., this report 
indicating that there is likely some subsurface flow at depth in Double Canyon. The flora of the rugged Arrow Canyon Range is poorly known and, therefore, the designation of extralimital to some of the mesophytic species recovered from the Double Canyon middens is conjectural (Table 12).The range has a maximum elevation of $1593 \mathrm{~m}$, and high-desert plants such as blackbrush, cliff-rose, and Joshua-tree likely occur somewhere in this massif. Other species typical of woodland, such as Utah juniper and single-leaf ash, may be altogether absent (Table 12).

Table 12. Selected Plant Species From the Double Canyon Packrat Middens.

\begin{tabular}{|c|c|c|c|c|c|}
\hline & $\begin{array}{l}\text { Site and sample no.: } \\
\text { Approximate14-C age }\end{array}$ & & $\begin{array}{l}\text { Modern } \\
\text { veg. }\end{array}$ & $\begin{array}{l}D C-1(1) \\
12,060\end{array}$ & $\begin{array}{c}\text { DC- } 4(2) \\
10,400\end{array}$ \\
\hline TREES, SHRUBS, AI & D SUCCULENTS & & & & \\
\hline COMMON NAME & GENUS AND SPECIES & AFFINITY & & & \\
\hline Apache plume & Fallugia paradoxa & 1 & - & - & 1 \\
\hline big bursage & Ambrosia eriocentra & $\mathrm{DR}$ & $*$ & - & - \\
\hline blackbrush & Coleogyne ramosissima & $!$ & - & - & 3 \\
\hline box-thorn & Lycium andersonii & - & 2 & - & - \\
\hline brickell-bush & Brickellia arguta & - & 2 & - & - \\
\hline catclaw acacia & Acacia greggii & $\mathbf{b}$ & * & - & - \\
\hline cliff-rose & Cowania mexicana & $!(?)$ & - & - & 4 \\
\hline creosote bush & Larrea divaricata & - & 3 & - & - \\
\hline currant & Ribes cf. velutinum & $! !(?)$ & - & 1 & - \\
\hline desert almond & Prunus fasciculata & - & 1 & 1 & 2 \\
\hline desert rabbitbrush & Chrysothamnus paniculattus & $\mathrm{DR}$ & * & - & - \\
\hline desert willow & Chilopsis linearis & $\mathrm{h}$ & * & - & - \\
\hline globe-mallow & Sphaeralcea ambigua & - & 3 & - & - \\
\hline globe-mallow & Sphaeralcea sp. & - & - & - & 1 \\
\hline grizly-bear prickly-pear & Opuntia erinacea & - & 1 & 1 & 2 \\
\hline indigo bush & Psorothamnus cf. fremontii & $!$ & - & - & 1 \\
\hline Joshua-tree & Yucca brevifolia & $!$ & - & - & 2 \\
\hline matchweed & Gutierrezia microcephala & - & 1 & 1 & 1 \\
\hline mesquite & Prosopis juliflora & $\mathrm{H}$ & * & - & - \\
\hline Mormon-tea & Ephedra nevadensis & - & * & - & - \\
\hline Mormon-tea & Ephedra nevadensis-type & - & - & - & 1 \\
\hline rubber rabbitbrush & Chrysothamnus nauseosus & 1 & - & 1 & - \\
\hline sage & Salvia dorrii & 1 & - & 1 & 2 \\
\hline shadscale & Atriplex confertifolia & 1 & - & 1 & - \\
\hline single-leaf ash & Fraxinus anomala & $!(?)$ & - & 1 & - \\
\hline snowberry & Symphoricarpos cf. longiflorus & $i$ & - & 2 & 1 \\
\hline
\end{tabular}


Table 12 (continued)

\begin{tabular}{|c|c|c|c|c|c|}
\hline & $\begin{array}{r}\text { Site and sample no.: } \\
\text { Approximate14-C age }\end{array}$ & & $\begin{array}{l}\text { Modern } \\
\text { veg. }\end{array}$ & $\begin{array}{l}\text { DC-1(1) } \\
12,060\end{array}$ & $\begin{array}{c}\text { DC- } 4(2) \\
10,400\end{array}$ \\
\hline Utah juniper & Juniperus osteosperma & !!(?) & - & 5 & 1 \\
\hline Whipple cholla & Opuntia whipplei & $!$ & - & 3 & - \\
\hline white bursage & Ambrosia dumosa & - & 2 & - & - \\
\hline $\begin{array}{c}\text { HERBS, FORBS, } \\
\text { AND GRASSES } \\
\text { FAMILY }\end{array}$ & GENUS AND SPECIES & AFFINITY & & & .. \\
\hline curly dock & Rumex salicilifolius & $\mathrm{aH}$ & * & - & - \\
\hline grasses & Poaceae undetermined & - & - & 1 & 1 \\
\hline $\begin{array}{l}\text { mistletoe } \\
\text { rockwort }\end{array}$ & $\begin{array}{l}\text { Phoradendron californicum } \\
\text { Scopulophila rixfordii }\end{array}$ & b & $* *$ & i & $\dot{3}$ \\
\hline
\end{tabular}

Relative Abundance Values: 1 , rare; 2, occasional; 3 , common; 4, abundant; 5, very abundant; $x$ present * restricted to Pahranagat Wash; ** in the immediate vicinity, but more than $30 \mathrm{~m}$ distant from the sites $\mathrm{DR}$, desert riparian species; $\mathrm{H}$ - obligate hydrophile or phreatophyte; $\mathrm{h}$ - facultative hydrophile or phreatophyte 1, extralocal; II extralimital

The difference between the two dated macrofossil assemblages from Double Canyon (Table 12) reflects not only the habitat differences between the two sites (Table 8), but also the degree of deglacial vegetation change that occurred here between ca. 12,060 and 10,400 B.P. The older assemblage, DC-1(1), is dominated by Utah juniper, Whipple cholla, and snowberry, species typical of xeric woodland. Shadscale and rubber rabbitbrush are also present (Table 12), plants characteristic of Great Basin desert scrub. Their presence in this older assemblage is consistent with a regional pattern of steppe shrub occurrence in glacial-age woodland (Spaulding, 1985). Single-leaf ash also occurs in the DC-1(1) assemblage (Table 12) which, with the records from Fortymile Canyon (Table 2), point to the importance of this Colorado Plateau species in the glacialage woodland of the northern Mojave Desert.

Utah juniper and snowberry are but rare in the DC-4(2) macrofossil assemblage, which is dominated by cliff-rose, blackbrush, and rockwort. Cliff-rose and blackbrush, along with other species such as desert almond and Joshua-tree, indicate a shift from xeric juniper woodland to mesic desert scrub here between ca. 12,060 and 10,400 B.P. (Table 12). However, when contrasted to the present xeric desert scrub of the Double Canyon area, it is obvious that effective moisture was still much greater than the present at 10,400 B.P. 
The available pollen data show that the DC-1(1) assemblage is dominated by Utah juniper (69.4\%; Table 10). Such a high frequency of juniper pollen is likely the result of the inclusion of pollen-bearing male cones in the midden. The absence of the macrofossils of hydrophilic species (Table 12), and dearth of pollen of these plants (Table 10) sheds no light on hydrologic conditions in the Double Canyon area.

\section{DISCUSSION}

As noted in the introduction to this report, this research has as its main objective the improvement of our understanding of the nature and magnitude of hydrologic changes in the vicinity of the proposed Yucca Mountain High-Level Waste Repository. Achievement of this objective relies on a limited set of new macrofossil and pollen data from three localities in southern Nevada. These data do provide some new insights into the hydrologic impact of former, wetter climatic regimes in the vicinity of Yucca Mountain, as well as the basis for pointing to some anomalies in the paleohydrologic record. These anomalies, if not artifacts of the data itself, are also of importance in furthering our efforts to assess the performance of the proposed Repository under a range of climatic and hydrologic conditions.

\section{LATE QUATERNARY HYDROLOGIC VARIATIONS}

The evidence for changes in the hydrologic regime in the vicinity of Yucca Mountain consists of local and regional data. The local evidence developed here comes from packrat middens from the middle reaches of Fortymile Canyon, less than $10 \mathrm{~km}$ northwest of Yucca Mountain (Figure 1), and are the basis for estimating the magnitude of both geomorphic and hydrologic changes. The regional paleoecological and paleohydrologic record provides a more comprehensive understanding of the chronology of hydrologic changes and, by virtue of a reasonably well-controlled chronology, an understanding of the potential linkages between hydrologic changes and changes in global climatic circulation patterns. 


\section{Local Evidence of Hydrologic Change Prior To The Last Glacial}

Maximum

As has been discussed, the plant macrofossil assemblages from the Fortymile Canyon-7 midden (FMC-7) offer unequivocal evidence for the presence of perennial water there at $>52,000$ and $47,240 \pm 3,000$ B.P. The evidence comes in the form of macrofossils and pollen of hydrophilic plants (Tables $6,7 \mathrm{~A}$ ), species that only occur in habitats characterized by the year-round presence of water. This indicates either perennial flow in Fortymile Canyon at the time the midden assemblages were deposited, or the presence of a spring in the vicinity of the FMC-7 site. In either case, an elevated water table is indicated.

Hydrologic modeling by Czarnecki (1985) indicates the possibility of numerous springs in this stretch of Fortymile Canyon in response to a projected 100\% increase in precipitation. The presence of hydrophilic plants in the FMC-7 fossil assemblages could thus be attributed to a perched spring high above Fortymile Canyon (Figure 2). However, the ecology of another fossil plant species argues against this interpretation. Arroyo bursage (Ambrosia cf. acanthicarpa) occurs along ephemeral or perennial water courses in the region, and can be found along Fortymile Canyon today (Beatley, 1976). It's recovery from the FMC-7(1) assemblage (Table 7A) suggests that expanses of sandy, disturbed habitat were available within the foraging range of the packrats inhabiting the FMC-7 site. It is therefore more likely that the site was within ca. $30 \mathrm{~m}$ of the Fortymile Canyon drainage during the time this midden accumulated. Because FMC7 is ca. $75 \mathrm{~m}$ above the current drainage of Fortymile Canyon (Table 3), it appears that major incision of the alluvial bed of this canyon occurred during the last ca. 73,000 years.

Following this reasoning, there was at least 45 additional meters of saturated alluvium in Fortymile Canyon in order to make riparian habitat accessible to packrats inhabiting the FMC-7 site. Although of geomorphic significance, the presence of this thickness of highly permeable alluvium itself has little hydrologic significance. What is hydrologically significant is the minimum change in water-table elevation ( $\triangle \mathrm{WT})$ that can be calculated from these values. Waddell et al. (1984) report that the present elevation of the water table in this area is ca. $1185 \mathrm{~m}$. Therefore $\Delta \mathrm{WT}$ would have to 
have been at least $65 \mathrm{~m}$ to bring perennially wet habitat within foraging range of the FMC-7 packrats. This is a minimum estimate, since $\Delta \mathrm{TW} \approx 65 \mathrm{~m}$ would bring the water table not to the FMC-7 site, but approximately $30 \mathrm{~m}$ below it. This also provides an upper limit to $\Delta \mathrm{WT}$ of ca. $95 \mathrm{~m}$ during the Wisconsin glacial age. Packrat middens are preserved through mummification and a water-table rise above this value would have destroyed the FMC-7 deposit.

A $\Delta W T$ of $65 \leq 95 \mathrm{~m}$ is far in excess of the maximum value of $9 \mathrm{~m}$ reported by Szabo et al. (1994) for the last $120,000 \mathrm{yr}$, based on their study of calcite deposits from Browns Room in Devils Hole. It is less that $\Delta \mathrm{WT} \approx 115 \mathrm{~m}$ indicated by the Lathrop Well diatomite deposits which, although not securely dated, are likely to be pre-Wisconsin in age (Quade et al., in press). In their survey of Late Quaternary paleospring deposits in the Amargosa Desert, Winograd and Doty (1980) were unable to find evidence of $\Delta W T$ $>50 \mathrm{~m}$ in the vicinity of Ash Meadows. Elsewhere in southern Nevada and adjacent California, Quade et al. (in press) were unable to find paleospring evidence of $\Delta \mathrm{WT}>90$ $\mathrm{m}$ (excepting the Lathrop Well diatomite), and most $\Delta \mathrm{WT}$ values range from 10 to $40 \mathrm{~m}$. Somewhat higher values, indicated by the FMC-7 midden assemblage, may be explained by a pronounced hydrologic gradient that exists immediately north and west of Yucca Mountain (Dudley, 1990 in National Research Council, 1992, Fig. 3.2). Finally, the FMC-7 site plots within an area which, in Czarnecki's (1985) model, experiences $\Delta \mathrm{WT} 50<100 \mathrm{~m}$ in response to a $100 \%$ increase in precipitation.

\section{Local Evidence During The Last Glacial Maximum}

With the above discussions in mind, it is interesting to note that the elevation of the FMC-8 site (Table 1) relative to the current water-table elevation (Waddell et al., 1984), constrains maximum $\triangle W T$ during the Late Wisconsin and early Holocene (including the last glacial maximum). If $\Delta \mathrm{WT}$ had exceeded $30 \mathrm{~m}$ at any time during the last $18,500 \mathrm{yr}$ (the age of the FMC-8 assemblage; Table 1), then that deposit would have been destroyed. A modest $\Delta W T$ of $<30 \mathrm{~m}$ is consistent with the absence of macrofossils of hydrophilic plants from the Late Wisconsin and early Holocene midden assemblages, This absence of evidence for a substantial increase in water-table elevation is contrary to the view that the last glacial maximum was the wettest climatic interval during the Late Quaternary (e.g. Forester, 1994). It also does not accord well with the apparent fact that 
Unit E time (ca. 14,000 to 8,500 B.P.; Haynes 1967) was a time of increased spring discharge in the valley bottoms (Quade, 1986).

The pollen samples from the Late Wisconsin middens in Fortymile Canyon (Table 6) indicate greater frequencies of hydrophile pollen (HP) than expected based on the modern control samples (Table 5), but is HP sufficiently abundant to rule out the possibility that it originated from expanded valley-bottom wet-lands tens of kilometers to the south? The average of $\Sigma H P$ in the control samples is $0.3 \% \pm 0.3 \%$, while in the Late Wisconsin and early Holocene-age samples it is $0.7 \% \pm 0.45 \%$. Thus, HP frequencies in most samples may represent the background produced by long-distance transport, with the possible exception of the FMC-11A(1) sample ( $\Sigma H P=1.5 \%$ ). The data from this sample may indicate perennial water in Fortymile Canyon at the time of its deposition (ca. 15,900 B.P.).

The pollen of sedge (Cyperaceae; Table 6) provides some evidence that riparian habitat(s) existed nearby in Fortymile Canyon. Sedge pollen is thin-walled and therefore susceptible to rapid degradation, and is rarely encountered as an element in the regional pollen rain. Indeed, none was found in any of the Holocene or modern pollen samples analyzed in this study (Tables 5, 6, and 10). Sedge grains were encountered in the FMC-7(3) and FMC-11A(1) samples, as well as in the sample from FMC-9A, the latter associated with a ${ }^{14} \mathrm{C}$ date of $\mathrm{ca} .21,800$ B.P. (Table 6). Therefore, it is possible that elevated $\Sigma H P$ frequencies and the sedge pollen grains indicate the local presence of perennial water.

\section{The Regional Paleohydrologic Records}

The chronology, as well as the magnitude, of paleohydrologic changes is important to a better understanding of the hydrologic stability of the Yucca Mountain area. Although this report focuses on paleoecological records of former, wetter habitats, these findings need to be considered in light of a regional paleohydrologic record that is dominated by evidence from paleospring deposits (e.g. Haynes, 1967; Quade, 1986; Quade and Pratt, 1989; Quade et al., in press). 


\section{The Paucity of Regional Glacial-Maximum Records}

Paleospring deposits in southern Nevada and adjacent California are often cited as providing evidence for increased discharge, and therefore increased water-table elevation, during the last glacial maximum. However, a consideration of the age of these deposits casts doubt on the chronological aspects of this assumption. Radiocarbon dating of Units $D$ and $E$, the youngest stratigraphic units associated with extensive marsh and pond environments in the valley bottoms, have returned no dates that can be firmly associated with the full glacial (broadly, $18,000 \pm 3,000$ B.P.), with one exception from the base of Unit $E$ (Table 13). A dry and cold full-glacial climate, relative to many models of pluvial climates (see summary in Spaulding et al., 1983) may thus account for the apparent absence of spring discharge then (Table 13). "Dry and cold" here refers to an increase in average annual precipitation of $\leq 40 \%$, and a decline in average annual temperatures of $6^{\circ}$ to $7^{\circ} \mathrm{C}$ (Spaulding, 1985).

In this light the Late Wisconsin and early Holocene record of water-table decline in Devils Hole, adjacent to Ash Meadows in the Amargosa Desert (Szabo et al., 1994), needs to be considered. Uranium series dates on calcite formed at or below the water table have been interpreted as indicating a maximum $\Delta \mathrm{WT}$ of $9 \mathrm{~m}$ from ca. 30,000 to 20,000 B.P., followed by a rapid decline to $6 \mathrm{~m}$ at ca. 17,000 B.P., continuing to 3.7 $\mathrm{m}$ at ca. $9,800 \mathrm{~B}$.P. But evidence for the persistence of maximum $\triangle \mathrm{WT}$ until ca. 20,000 B.P. can be questioned because it is constrained by only one date with a large error (19,600 $\pm 1,400$ B.P.), corrected for detrital $230 \mathrm{Th}$ using assumed initial isotopic ratios (the uncorrected age is $20,500 \pm 1,600$ B.P.; Szabo et al., 1994, p. 63). Therefore it is possible that the initial decline in water table elevation may have been earlier, closer to the end of Unit D time (Table 13).

Another intriguing aspect of the data presented by Szabo et al. (1994) is the absence of hydrologic evidence from Devils Hole for an increase in $\triangle \mathrm{WT}$ correlated with Unit $\mathrm{E}$ time. Their curve (ibid., p. 64) shows a nearly monotonic decline in water-table elevation in Devils Hole through Unit $\mathrm{E}$ time (Table 13). The absence of evidence for an increase in $\triangle W T$ during a period when the sedimentary record suggests a region-wide episode of spring discharge is enigmatic. The two possible explanations are: 
Table 13. Radiocarbon Dates on Paleospring Deposits: Units D and E.

\begin{tabular}{|c|c|c|c|c|c|c|c|}
\hline Locality & Unit & 14-C Date & $\begin{array}{l}\text { Standard } \\
\text { Deviation } \\
\end{array}$ & $\begin{array}{c}\text { Material } \\
\text { dated }\end{array}$ & $\begin{array}{c}\text { Laboratory } \\
\text { number }\end{array}$ & Reference & Remarks \\
\hline Tule Springs & E2 & 7,480 & 120 & $\mathrm{~W}$ & UCLA-519 & Haynes, 1967 & - \\
\hline Eglington Scarp & E2 & 8,000 & 400 & W & UCLA-548 & Haynes, 1967 & - \\
\hline Tule Springs & $\mathrm{E} 2$ & 8,540 & 340 & W & A-463a & Haynes, 1967 & - \\
\hline Pahrump Valley & $\mathrm{E}$ & 8,570 & 170 & C & A-4590 & Quade et al., in press & - \\
\hline Corn Creek Flat & E2 & 8,640 & 150 & $\mathrm{OM}$ & A-2571 & Quade, 1986 & - \\
\hline Tule Springs & E2 & 9,000 & 1,000 & W & UCLA-510 & Haynes, 1967 & - \\
\hline Gilcrease Ranch & E2 & 9,200 & 250 & $\mathrm{OM}$ & UCLA-529 & Haynes, 1967 & - \\
\hline Corn Creek Flat & $\mathbf{E}$ & 9,220 & 180 & $\mathrm{OM}$ & $A-4861$ & Quade et al., in press & - \\
\hline Eglington Scarp & E2 & 9,350 & 200 & $\mathrm{OM}$ & UCLA-551 & Haynes, 1967 & - \\
\hline Tule Springs Flat & E2 & 9,370 & 210 & $\mathrm{~W}$ & A-2545 & Quade, 1986 & - \\
\hline Cactus Springs & $\mathrm{E}$ & 9,460 & 70 & $\mathrm{OM}$ & USGS-2213 & Quade and Pratt, 1989 & - \\
\hline N. Coyote Springs & $\mathrm{E}$ & 9,500 & 280 & OM & A-5223 & Quade et al., in press & - \\
\hline Eglington Scarp & $\mathrm{E} 2$ & 9,520 & 300 & $\mathrm{OM}$ & UCLA-549 & Haynes, 1967 & - \\
\hline Tule Springs & E2 & 9,670 & 200 & $\mathbf{W}$ & I-991 & Haynes, 1967 & - \\
\hline Cactus Springs & $\mathbf{E}$ & 9,680 & 100 & OM & USGS-2212 & Quade and Pratt, 1989 & - \\
\hline Eglington Scarp & $\mathbf{E}$ & 9,820 & 100 & $\mathrm{OM}$ & Beta- -45473 & Dames \& Moore, 1992 & - \\
\hline Eglington Scarp & E2 & 9,870 & 400 & $\mathrm{OM}$ & A-464 & Haynes, 1967 & - \\
\hline Gilcrease Ranch & E2 & 9,920 & 150 & $\mathrm{OM}$ & UCLA-537 & Haynes, 1967 & - \\
\hline S. Coyote Springs & $\mathbf{E}$ & 9,970 & 90 & $\mathrm{OM}$ & A-5222 & Quade et al., in press & - \\
\hline Tule Springs & E2 & 10,000 & 200 & $\mathrm{~W}$ & UCLA-505 & Haynes, 1967 & - \\
\hline Corn Creek Flat & E2 & 10,090 & 160 & $\mathrm{OM}$ & A-2585 & Quade, 1986 & - \\
\hline Corn Creek Flat & $\mathbf{E}$ & 10,140 & 130 & $\mathrm{OM}$ & A-4993 & Quade et al., in press & - \\
\hline Corn Creek Springs & E2 & 10,200 & 350 & OM & UCLA-542 & Haynes, 1967 & - \\
\hline Valley Wells & $\bar{E}$ & 10,250 & 160 & OM & A-4869 & Quade et al., in press & - \\
\hline Pahrump Valley & $\mathrm{E}$ & 10,380 & 380 & w & A-4594 & Quade et al., in press & - \\
\hline Indian Springs & $\mathrm{E}$ & 10,410 & 110 & $\mathrm{OM}$ & A-5305 & Quade et al., in press & - \\
\hline Corn Creek Springs & E2 & 10,800 & 300 & OM & UCLA-530 & Haynes, 1967 & - \\
\hline Pahrump Valley & $\mathrm{E}$ & 10,940 & 390 & w & A-4593 & Quade et al., in press & - \\
\hline Corn Creek Flat & E2 & 10,980 & 270 & $\mathrm{~W}$ & A-2465 & Quade, 1986 & - \\
\hline Sandy Valley & $\mathrm{E}$ & 11,020 & 140 & $\mathrm{OM}$ & A-4986 & Quade et al., in press & - \\
\hline Eglington Scarp & E2 & 11,100 & 200 & $\mathrm{OM}$ & UCLA-550 & Haynes, 1967 & - \\
\hline
\end{tabular}


Table 13 (continued)

\begin{tabular}{|c|c|c|c|c|c|c|c|}
\hline Locality & Unit & 14-C Date & $\begin{array}{l}\text { Standard } \\
\text { Deviation }\end{array}$ & $\begin{array}{c}\text { Material } \\
\text { dated }\end{array}$ & $\begin{array}{l}\text { Laboratory } \\
\text { number }\end{array}$ & Reference & Remarks \\
\hline Pahrump Valley & $\mathbf{E}$ & 11,190 & 210 & $\mathrm{~W}$ & A-4592 & Quade et al., in press & - \\
\hline Tule Springs & E2 & 11,200 & 200 & W & UCLA-508 & Haynes, 1967 & - \\
\hline Tule Springs & E1 & 11,500 & 500 & W & UCLA-636 & Haynes, 1967 & - \\
\hline Eglington Scarp & B & 11,630 & 90 & $\mathrm{OM}$ & Beta- 45472 & DuBarton et al., 1991 & $=$ \\
\hline Corn Creek Springs & E1 & 11,700 & 250 & $\mathrm{OM}$ & UCLA-541 & Haynes, 1967 & - \\
\hline Corn Creek Flat & $\mathrm{E}$ & 11,760 & 130 & $\mathrm{OM}$ & A-4996 & Quade et al., in press & - \\
\hline Corn Creek Flat & $\mathrm{E}$ & 11,870 & 200 & $\mathrm{~W}$ & A-4901 & Quade et al., in press & - \\
\hline Tule Springs & E1 & 11,900 & 250 & W & UCLA-637 & Haynes, 1967 & - \\
\hline Tule Springs & E1 & 12,270 & 200 & W & UCLA-507 & Haynes, 1967 & - \\
\hline Tule Springs & E1 & 12,300 & 350 & $\mathrm{w}$ & UCLA-514 & Haynes, 1967 & - \\
\hline Tule Springs & E1 & 12,400 & 200 & W & UCLA-604 & Haynes, 1967 & - \\
\hline Tule Springs & E1 & 12,400 & 350 & $w$ & UCLA-512 & Haynes, 1967 & - \\
\hline Tule Springs & E1 & 12,450 & 230 & W & UCLA-509 & Haynes, 1967 & - \\
\hline Corn Creek Flat & E1 & 12,600 & 300 & $\mathrm{~W}$ & W-5643 & Quade, 1986 & - \\
\hline Corn Creek Flat & $\mathrm{E} 1$ & 12,630 & 300 & $\mathrm{~W}$ & W-5646 & Quade, 1986 & - \\
\hline Tule Springs & E1 & 12,650 & 200 & w & UCLA-518 & Haynes, 1967 & - \\
\hline Tule Springs & E1 & 12,920 & 220 & W & UCLA-521 & Haynes, 1967 & - \\
\hline Tule Springs & E1 & 13,000 & 200 & W & UCLA-552 & Haynes, 1967 & - \\
\hline Tule Springs & E1 & 13,100 & 200 & $\mathrm{~W}$ & UCLA-522 & Haynes, 1967 & - \\
\hline Corn Creek Flat & E1 & 13,830 & 400 & W & W-5643 & Quade, 1986 & - \\
\hline Corn Creek Flat & E1 & 14,040 & 320 & W & W-5649 & Quade, 1986 & - \\
\hline Eglington Scarp & $\mathrm{E}$ & 15,610 & 100 & $\mathbf{W}$ & Beta-45474 & Dames \& Moore, 1992 & From channel bottom: basal date \\
\hline "Gilcrease Ranch" & D"' & 25,300 & 2,500 & $w$ & UCLA-539 & Haynes, 1967 & - \\
\hline Tule Springs Area & $\mathrm{D}$ & 26,800 & 700 & w & Beta-61581 & McVickar and Spaulding, 1993 & - \\
\hline Tule Springs Area & D & 27,580 & 650 & W & Beta-62510 & McVickar and Spaulding, 1993 & - \\
\hline Pahrump Valley & "pre-D" & 31,790 & $+1,580 /-1,290$ & W & A-4897 & Quade et al., in press & Minimum age-rootlets \\
\hline Cactus Springs & $D(?)$ & 42,600 & 1,600 & W & USGS-2211 & Quade and Pratt, 1989 & "Probably too old" \\
\hline Tule Springs & D & $>35,000$ & - & W & UCLA-513 & Haynes, 1967 & Possibly redeposited \\
\hline
\end{tabular}

W, carbonized wood; OM, organic mat; $C$, charcoal

Note: Dates on tufa, other carbonate, and shell are considered to be unreliable due to initial 14-C deficiencies (Haynes, 1967; Riggs, 1984), and are not considered. 
(1) Unit E sediments do not indicate a regional reactivation of spring discharge after a period of senescence. Instead, they suggest progressive decline in discharge through the Late Wisconsin and early Holocene from a full-glacial maximum. The problem with this hypothesis is that there are no demonstrably full-glacial spring sediments (Table 13).

(2) The spread of dated Devils Hole calcite samples during the Late Wisconsin (2 or 3 depending on interpretation of the standard deviation of one date; Szabo et al., 1994) is too sparse to detect an increase in $\triangle W T$ that may have been relatively short-lived $(3,000$ to $6,000 \mathrm{yr})$.

\section{Early Holocene Paleohydrologic Records}

Table 11 presents the macrofossil records of hydrophilic plant species (and one animal) recovered from the Yucca Mountain region. Net-leaf hackberry (Celtis reticulata) is the most common macrofossil found, usually as single seeds representing long-distance transport. A burgeoning population of net-leaf hackberry in the valley-bottom springs late in Unit $\mathrm{E}_{2}$ time (ca. 11,200 to 8,500 B.P.; Table 13) in response to increased spring discharge is the most likely cause of this apparent increase in seed fallout (Table 11). The current range of hackberry extends far north into central Washington State (Little, 1976) and, therefore, its absence from older middens in this area cannot be attributed to frigid temperatures during the last glacial age. Two enigmatic aspects of this record are:

1) No hydrophilic species have been recovered from the numerous, full-glacial age middens in the region (e.g. Spaulding, 1990a; Wigand, 1990). This could be expected if the full-glacial climate was relatively dry and cold, as discussed above.

2) No hydrophilic species have been recovered from the numerous, latestWisconsin age middens in region. There are macrofossils of riparian species from actual spring and valley-fill sediments, but there are no midden records of these plants that correlate with Unit $E$ time older than ca. 9,600 B.P. This is strange since the Unit $\mathrm{E}$ stratigraphic record suggests increased spring discharge beginning ca. 13,000 B.P. (Table 13). 
In light of these records (Table 11), a peak in hackberry pollen dating to the last deglaciation in a core from the Gulf of California, ca. $800 \mathrm{~km}$ southeast of the southern boundary of the Mojave Desert (Figure 3; Byrne, 1982; Byrne et al., 1989), is intriguing. The reanalysis of the packrat midden data of Cole $(1981,1982$; central Grand Canyon) and Van Devender (1987; southwestern Arizona) by Davis and Shafer (1992, Figure 6) also suggest an early Holocene precipitation maximum of regional extent. If a region-wide pluvial event occurred during the early Holocene, then its climatic attributes were probably fundamentally different from pluvial episodes during the last glacial age. Although this could have been due to an intensification of monsoonal flow (Spaulding and Graumlich, 1986; Spaulding, 1991b), other analyses suggest that circulation patterns commonly associated today with El Niño-type events may have been responsible (Enzel et al., 1989).

\section{Evidence From Sandy Valley}

Along with attempting to place the paleobiotic data in the broader context of changes in the hydrologic regime in the vicinity of Yucca Mountain, this section of the report has attempted to point to several anomalies in the paleohydrologic record as inferred from spring deposits and packrat middens. The last anomaly discussed above, which can be rephrased as "younger middens within the early Holocene are more likely to yield the remains of hydrophilic species than older middens," is relevant to a final consideration of the Sandy Valley midden sequence. The only hydrophilic species recovered here was honey mesquite, found in the youngest sample (SaV-3(1)), dating to ca. 8,500 B.P. (Table 9). None of the older Sandy Valley samples, dating back to ca. 9,400 B.P., provide pollen or macrofossil evidence for the presence of phreatophytic plant species in the immediate vicinity. Moreover, arboreal pollen tends to increase in the younger samples (Table 10), which may suggest increasingly mesic conditions. Alternatively, progressive desertification during the early Holocene led to more open vegetation conditions in the immediate vicinity. The consequent decline in local pollen production could have resulted in an increase in the relative proportion of arboreal pollen from distant source areas. This may explain an anomalous pollen record, but it does not help to explain the absence of phreatophytes from most of the Sandy Valley macrofossil records. 
A $\triangle W T$ of 10 to $20 \mathrm{~m}$ in the vicinity of the Sandy Valley midden sites (Quade et al., in press) should have promoted the growth of other riparian species besides mesquite, at least in proximity to the SaV-3 site (Figure 3; Table 8 ). A ${ }^{14} \mathrm{C}$ date of $11,020 \pm 140$ B.P. on an organic mat from the paleospring deposits nearby (ibid.) shows that an elevated water table and attendant increased spring discharge occurred well before the deposition of the oldest Sandy Valley midden sample. The absence of phreatophyte pollen or macrofossils from these older samples (Tables 9, 10) therefore presents a final enigma.

\section{SUMMARY AND RECOMMENDATIONS}

The most important findings from this study come from the packrat middens recovered closest to Yucca Mountain. The Fortymile Canyon-7 macrofossil and pollen assemblages provide evidence for much different geomorphic and hydrologic conditions than are currently found there. Although these two samples are at the limit or beyond the range of radiocarbon dating, they contain a floristic assemblage dominated by species characteristic of a glacial climatic regime and therefore likely date to the Early or earlyMiddle Wisconsin (ca. 73,000 to 47,000 B.P.). The remains of willow, wild-rose, and marsh knotweed indicate that the water table was at least $75 \mathrm{~m}$ higher at that time, while the position of the midden itself constrains $\Delta \mathrm{WT}$ to $\diamond 5 \mathrm{~m}$.

It also appears likely that the bed of Fortymile Canyon was 75 to $95 \mathrm{~m}$ higher than today, and that the alluvium filling it was largely removed prior to ca. 18,500 B.P. This latter date is provided by a midden that was recovered only ca. $10 \mathrm{~m}$ above the current floor of the canyon. The timing of removal of $\geq 65 \mathrm{~m}$ of alluvium from the middle reaches of Fortymile Canyon (18,500<47,000 B.P.), and its consequent deposition farther downstream, may help in developing a better understanding of the geomorphic evolution of the Jackass Flats area (e.g. Lundstrom et al., in press).

While a value of $\Delta W T$ of $75 \leq 95 \mathrm{~m}$ is considerable, it is much less than the $>400 \mathrm{~m}$ water-table rise proposed by Szymanski (1989; see also Archambeau and Price, 1991; National Research Council, 1992). It is within the range of values determined by Quade et al. (in press), based on their study of Late Quaternary spring deposits in the region, and also within the range of modeled values in response to a $100 \%$ increase in precipitation (Czarnecki, 1985). And, although a study of the potential effects of a $400 \%$ 
increase in rainfall proposed by Forester (1994) is beyond the scope of this project, the paleoecological or paleohydrologic evidence considered here provide no immediately obvious support for such a thesis.

Younger Fortymile Canyon middens, dating to the Late Wisconsin and early Holocene, yield little evidence for perennial water or an elevated water table, even though some of these are much closer to the current drainage of the canyon. In opposition to Early or early-Middle Wisconsin conditions, $\Delta W T$ was $\leq 30 \mathrm{~m}$ between ca. $22,000 \mathrm{yr}$ and the present. Occasional pollen of sedge, and elevated frequencies of hydrophile pollen in one sample, suggest the presence of perennially wet habitats at ca. 21,800 and 15,900 B.P. But their nature (seep, spring, or stream) and extent cannot be determined given the sparse data. The paucity of evidence for perennial water during the last glacial maximum accords with an absence of paleospring deposits dating to this period (Table 13), and is consistent with paleoclimatic reconstructions indicating a relatively dry and cold environment at this time (Spaulding, 1985). Stratigraphic sequences suggesting widespread spring discharge in the nearby valleys are older than 25,000 B.P., or younger than ca. 13,000 B.P. The younger, Unit $E$ sediments generally date from ca. 13,000 to 8,500 B.P.

In the Sandy Valley midden sequence, only the youngest assemblage $(8,490$ B.P.) yields evidence for phreatic habitats and a $\Delta W T$ of 10 to $20 \mathrm{~m}$, consistent with the estimates of Quade et al., in press). Other Sandy Valley samples as old as ca. 9,430 B.P., and two latest Wisconsin samples from Double Canyon in the Arrow Canyon Range, provide no evidence for phreatic habitats. This despite the presence of paleospring deposits nearby with ${ }^{14} \mathrm{C}$ dates that suggest active discharge during the time of midden deposition. In a similar vein, the regional packrat midden record provides evidence for increased fallout of the remains of hydrophilic species between ca. 9,800 and 8,500 B.P., but not prior to that time. This contrasts with the stratigraphic record of active spring discharge as early as ca. 13,000 B.P.

\section{RECOMMENDATIONS FOR FURTHER RESEARCH}

Inconsistencies between different data sets can point to important aspects of the climatichydrologic system of the Yucca Mountain area that remain overlooked (e.g. National Research Council, 1992). One of the most glaring in the data discussed here is the 
contrast between the widely held belief that the last glacial maximum was a time of maximum water-table rise and spring discharge, and the utter lack of stratigraphic evidence for spring discharge during that time. This suggests an important action item for further geochronological investigations in the vicinity of Yucca Mountain. A better appreciation of the actual chronology of $\Delta \mathrm{WT}$ and consequent spring discharge would lead to a better understanding of the climatic mechanisms that led to increased recharge.

Similarly, there appears to be a contrast between the timing of hydrophilic species occurrences in the regional midden record, tightly constrained to between ca. 9,800 and 8,500 B.P., and the broader chronology of spring discharge during Unit E time (ca. 13,000 to 8,500 B.P.). Statistical tests could be performed on this data set to determine whether this may be simply due to an abundance of midden samples dating to this period. It would also be appropriate to evaluate the effects of initial isotopic disequilibrium produced by bicarbonate-rich waters on the apparent ${ }^{14} \mathrm{C}$ age of "black mats," which have provided many Unit $\mathrm{E}$ dates.

This study is the first to attempt to utilize the rich fossil pollen flora in ancient packrat middens to determine whether phreatic habitats were present nearby, but beyond the ca. $30 \mathrm{~m}$ foraging range of packrats. The results of this effort were equivocal to the extent that the absence or very low frequencies of the pollen of hydrophilic plants could not be used as evidence that perennially wet habitats did not exist in the immediate area. For example, the Sandy Valley pollen samples largely failed to provide evidence of phreatic habitats nearby while, according to the stratigraphic record, there were such habitats within a kilometer of the sites. If palynology is be employed further toward this end, then one analytic approach should be changed. In their paleoecological and paleohydrologic reconstruction of presently-dry oases in the Libyan Desert, Ritchie et al. (1985) used pollen sums that exceeded 1,000 grains to gain statistically significant amounts of indicator pollen taxa. The pollen sums of ca. 350 grains used here are considered to be quite adequate for most palynological research goals, but evidently not for the search for evidence of nearby phreatic environments.

To the extent that certain, macrofossil-based reconstructions are either controversial or violate conventional wisdom, pollen analysis can provide additional information valuable in testing these hypotheses. For example, the Late Wisconsin Fortymile Canyon pollen assemblages clearly show that the vegetation was open and that 
sagebrush was an important component, reinforcing reconstructions that call for relative dry, cold glacial conditions. Had conditions prevailed that are typically invoked in models of an equable glaciopluvial ( $\geq 100 \%$ precipitation), sagebrush pollen would have been much less common, and frequencies of such taxa as pine would have been much higher. Therefore, palynology applied to ancient packrat middens should remain as a tool in paleoenvironmental reconstructions.

Finally, the results of this study demonstrate the importance of targeting midden collection efforts to specific areas in order to address carefully articulated research questions. The indiscriminate collection of middens from the region as a whole is not as likely to provide evidence useful in assessing repository performance. Despite a limited suite of samples collected in this project, targeting collection efforts yielded important new evidence of water-table fluctuations in the immediate vicinity of Yucca Mountain. Because of their implications for repository performance, findings from this study need to be tested through the development of a larger, targeted database. If these findings withstand further testing, then a $\Delta W T$ of $\leq 95 \mathrm{~m}$ was all that occurred during the Wisconsin glacial age in the vicinity of Yucca Mountain. A water-table rise of this magnitude would not affect the integrity of the repository, but changes in infiltration rates, ground-water travel time, and geomorphic stability may affect other aspects of repository performance. 


\section{LITERATURE CITED}

Anderson, R. S. (1990). Holocene forest development and paleoclimates within the central Sierra Nevada, California. Journal of Ecology 78: 470-489.

Anderson, R. Scoth, O. K. Davis, and P. L. Fall (1985). Late glacial and Holocene vegetation and climate in the Sierra Nevada of California, with particular reference to the Balsam Meadow site. In Late Quaternary vegetation and climates of the southwestern United States (B. F. Jacobs, P. L. Fall, and O. K. Davis, eds.). American Assoc. Stratigraphic Palynologists Contributions Series 16: 127-140.

Anderson, R. S., and Van Devender, T. R. (1991). Comparison of pollen and macrofossils in packrat (Neotoma) middens: A chronological sequence from the Waterman Mountains of southern Arizona, U. S. A. Review of Paleobotany And Palynology 68: 1-28.

Archambeau, C. B., and N. J. Price (1991). An assessment of J. S. Szymanski's hydrotectonic model and its relevance to hydrologic and geologic processes at the proposed Yucca Mountain Nuclear Waste Repository: A minority report of the Special U. S. Department of Energy Review panel, Nevada Operations Office, Las Vegas, Nevada.

Beatley, J. C. (1976). Vascular plants of the Nevada Test Site, and central-southern Nevada. National Technical Information Service Report TID-26881, 308 p.

Benson, Lyman, and Darrow, R.A. (1981). Trees and shrubs of the southwestern deserts. University of Arizona Press, Tucson.

Betancourt, J. L., T. R. Van Devender, and P. S. Martin (Eds.) (1990). Fossil packrat middens: The last 40,000 years of biotic change. University Arizona Press, Tucson.

Birks, H. J. B., and H. H. Birks (1980). Quaternary paleoecology: University Park Press, Baltimore, $\mathrm{MD}$.

Bradley, W. G., and J. E. Deacon (1967). The biotic communities of southern Nevada. In Pleistocene studies in southern Nevada (H. M. Wormington and D. Ellis, eds.). Nevada State Museum Anthropological Papers 13: 129-200.

Byrne, R. (1982). Preliminary pollen analysis of Deep Sea Drilling Project Leg 64, Hole 480, Cores 1-11. In Initial reports of the Deep Sea Drilling Project, Volume LXIV, part 2 (J. R. Curray, D. G. Moore, et al., authors), pp. 1225-1237. U. S. Government Printing Office, Washington, D. C. 
Byrne, R., P. Mudie, and A. Soutar (1989). A pollen/dinoflagellate chronology for DSDP Site 480, Gulf of California. In Proceeding of the 6th Annual Pacific Climate (PACLIM) Workshop, Asilomar, California. Technical Report of the Interagency Ecological Studies Program, Sacramento-San Joaquin Estuary

CLIMAP Project Members (1981). Seasonal reconstructions of the earth's surface at the last glacial maximum. Geological Society of America Map and Chart Series, MC36.

Cole, K. L. (1981). Late Quaternary environments in the eastern Grand Canyon, vegetational gradients over the last 25,000 years: Ph.D dissertation, University of Arizona, Tucson.

(1982). Late Quaternary zonation of vegetation in the eastern Grand Canyon. Science 217: 1142-1144.

Czarnecki, J. B. (1985). Simulated effects of increased recharge on the ground-water flow system of Yucca Mountain and vicinity, Nevada-Califomia. WaterResources Investigations Report 84-4344. U. S. Geological Survey, Denver.

Dames \& Moore (1992). Kern River Pipeline paleontologic resource final technical report Nevada portion. Dames \& Moore, Las Vegas.

Davis, O. K., and D. S. Shafer (1992). A Holocene climatic record for the Sonoran Desert from pollen analysis of Montezuma Well, Arizona, U.S.A. Palaeogeography, Palaeoclimatology, Palaeoecology 92: 107-119.

DuBarton, A. E., W. G. Spaulding, M. S. Kelly, and J. H. Cleland. (1991). City of Las Vegas land transfer final report on archaeological and paleoenvironmental testing of three sites along the Eglington Escarpment. Dames \& Moore, Las Vegas, NV.

Dudley, W. M. (1990). Gradients and stability of the hydraulic regime in the Yucca Mountain area. Presented at a meeting of the National Academy of Sciences Panel on Coupled Hydrologic/Tectonic/Hydrothermal Systems at Yucca Mountain, Menlo Park, Califomia.

Enzel, Yehouda, D. R. Cayan, R. Y. Anderson, and S. G. Wells (1989). Atmospheric circulation during Holocene lake stands in the Mojave Desert: Evidence of regional climate change. Nature 341: 44-48.

Faegri, Knut and J. Iversen (1975). Textbook of pollen analysis. Hafner Press, New York.

Forester, R. M. (1994). Late Glacial to modern climate near Yucca Mountain Nevada. In Proceedings of the International High-Level Radioactive Waste Management Conference. Las Vegas, NV. 
Haynes, C. V., Jr. (1967). Quaternary geology of the Tule Springs area, Clark County, Nevada. In Pleistocene studies in southern Nevada (H.M. Wormington and D. Ellis, Eds.). Nevada State Museum Anthropological Papers 13:15-104.

Hickman, J. C. (Ed.) 1993. The Jepson Manual: Higher plants of California. University of California Press, Berkeley.

Kearney, T. H., and R. H. Peebles (1969). Arizona flora. University of California Press, Berkeley.

Little, E.L., Jr. (1976) "Atlas of United States Trees" Vol. 3.Minor western hardwoods." U.S.D.A. Forest Service Misc. Publ. No. 1314.

Lundstrom, S. C., and R. G. Warren (1994). Late Cenozoic evolution of Fortymile Wash: major change in drainage pattern in the Yucca Mountain, Nevada region during Late Miocene volcanism. In Proceedings of the International High-Level Radioactive Waste Management Conference, pp. 2121-2130. Las Vegas, NV.

Lundstrom, S. C., J. R. Wesling, E. M. Taylor, and J. B. Paces (in press). Preliminary surficial deposits map of the Northeast 1/4 of the Busted Butte 7.5' Quadrangle, Nye County, Nevada. U. S. Geological Survey, Denver, CO.

Martinson, D. G., N. G. Pisias, J. D. Hays, J. Imbrie, T. C. Moore, Jr., and N. J. Shackleton (1987). Age dating and Orbital theory of the ice ages: development of a high-resolution 0 to 300,000-year chronostratigraphy. Quaternary Research 27: $1-29$.

McVickar, J. L., and W. G. Spaulding (1993). Monitoring and Mitigation of Paleontologic Resources Final Draft Technical Report Upper Las Vegas Wash Flood Control Facility Clark County, Nevada. Dames \& Moore, Las Vegas.

Mehringer, P.J., Jr., 1965, Late Pleistocene vegetation in the Mohave Desert of southern Nevada. Journal of the Arizona Academy Sciences 3: 172-188.

Mehringer, P.J., Jr., and C. W. Ferguson (1969). Pluvial occurrence of bristlecone pine (Pinus aristata) in a Mohave Desert mountain range. Journal of the Arizona Academy Sciences 5: 284-292.

Mix, A. C. (1987). The oxygen-isotope record of deglaciation. In The Geology of North America, v. K-3, North America and Adjacent Oceans During the Last Deglaciation (W. F. Ruddiman and H. E. Wright, Jr., Eds.), pp. 111-136. Geological Society of America, Boulder, $\mathrm{CO}$.

Munz, P.A. (1968). A California flora. University of California Press, Berkeley.

National Research Council (1992). Ground water at Yucca Mountain: how high can it rise? National Academy Press, Washington, D.C. 
Orkild, P. P., and J. T. O'Connor (1970). Geologic map of the Topopah Spring Quadrangle, Nye County, Nevada. U. S. Geological Survey, Washington, D. C. Peterson, P. M. (1984). Flora and physognomy of the Cottonwood Mountains Death Valley National Monument, California. Contribution No. CPSU/UNLV 022/06, Coorperative National Park Resources Study Unit, University of Nevada, Las Vegas.

Phillips, B.G., A. M. Phillips, III, and M.A.S. Bernzott (1987).Annotated checklist of the vascular plants of Grand Canyon National Park. Grand Canyon Natural History Association Monograph no. 8, 79 pp.

Quade, Jay (1986). Late Quaternary environmental changes in the Upper Las Vegas Valley, Nevada. Quaternary Research 26: 340-357.

Quade, Jay, and Pratt, W. L. (1989). Late Wisconsin groundwater discharge environments of the southwestern Indian Springs Valley, southern Nevada. Quaternary Research 31: 351-370.

Quade, Jay, M. D. Mifflin, W. L. Pratt, W. McCoy, and L. Burckle. In press. Spring deposits and water-table levels in the southern Great Basin during the Late Quaternary. Geological Society of America Bulletin.

Riggs, A. C. (1984). Major Carbon-14 deficiency in modern snail shells from southern Nevada springs. Science 224: 58-61.

Ritchie, J. C., C. H.Eyles, and C. V. Haynes (1985). Sediment and pollen evidence for an early to mid-Holocene humid period in the eastern Sahara. Nature 314, 352355.

Sorensen, T. (1948). A method of establishing groups of equal amplitude in plant sociology based on similarity of species content. Det Kongress Danske Videnske, Selskab Biologica Skrifter 5,1-34.

Spaulding, W.G. (1974). Pollen analysis of fossil dung of Ovis canadensis from southern Nevada." M.S. thesis, University of Arizona.

Spaulding, W.G. (1981). The late Quaternary vegetation of a southern Nevada mountain range. Ph.D. thesis, University of Arizona, Tucson.

(1983). Late Wisconsin macrofossil records of desert vegetation in the American southwest. Quaternary Research 19: 256-264.

(1985). Vegetation and climates of the last 45,000 years in the vicinity of the Nevada Test Site, south-central Nevada. U.S. Geological Survey Professional Paper 1329. 
Spaulding, W. G. (1990a). Vegetational and climatic development of the Mojave Desert: The last glacial maximum to the present. In Packrat middens: The last 40,000 years of biotic change (J. L. Betancourt, P. S. Martin, and T. R. Van Devender, Eds.). University of Arizona Press, Tucson. pp. 166-199.

(1990b). Vegetation dynamics during the last deglaciation, southeastern Great Basin, U.S.A. Quaternary Research, 33: 188-203.

(1992). The effects of pluvial climates in the vicinity of Yucca Mountain: A summary. In Ground water at Yucca Mountain- How high can it rise?, pp. 190211. National Research Council, National Academy of Sciences. National Academy Press, Washington, D. C.

Spaulding, W.G., E. B. Leopold, and T. R. Van Devender (1983). Late Wisconsin paleoecology of the American Southwest. In The Late Pleistocene (S. C. Porter, Ed.), pp. 259-293. Univ. Minnesota Press, Minneapolis.

Spaulding, W.G., Robinson, S.W., and Paillet, F.L. (1984). Preliminary assessment of climatic change during late Wisconsin time, southern Great Basin and vicinity, Arizona, California, and Nevada. U.S. Geological Survey Water-Resources Investigations Report 84-4328.

Spaulding, W.G., and L. J. Graumlich (1986). The last pluvial climatic episodes in the deserts of southwestern North America. Nature 320, 441-444.

Szabo, B. J., P. T. Kolesar, A. C. Riggs, I. J. Winograd, and K. R. Ludwig (1994). Paleoclimatic inferences from a 120,000-yr calcite record of water-table fluctuations in Browns Room of Devils Hole, Nevada. Quaternary Research 41: 59-69.

Szymanski, J. S. (1989). Conceptual model of the Yucca Mountain groundwater system with special emphasis on the adequacy of this system to accomodate a high-level nuclear waste repository. U. S. Department of Energy, Nevada Operations Office, Las Vegas, NV.

Thompson, R. S. (1988). Western North America: vegetation dynamics in the western United States; modes of response to climatic fluctuations. In Vegetation history (B. Huntley and T. Webb, III, Eds.), pp. 415-458. Kluwer Academic Publ., Boston.

(1990). Late Quaternary vegetation and climate in the Great Basin. In Packrat middens: The last 40,000 years of biotic change (J. L. Betancourt, P. S. Martin, and T. R. Van Devender, Eds.), pp. 200-239. University of Arizona Press, Tucson. 
Thompson, R. S., C. Whitlock, P. J. Bartlein, S. P. Harrison, and W. G. Spaulding (1993). Climatic changes in the western United States since 18,000 yr B.P. In Global climates since the last glacial maximum (H. E. Wright, Jr., J. E. Kutzbach, T. Webb, III, W. F. Ruddiman, F. A. Street-Perrott, and P. J. Bartlein, Eds.), pp. 469-513. University of Minnesota Press, Minneapolis.

Van Devender, T. R. (1987). Holocene vegetation and climate in the Puerto Blanco Mountains, southwestern Arizona. Quaternary Research 27, 51-72.

Waddell, R. K., J. H. Robison, and R. K. Blankennagel (1984). Hydrology of Yucca Mountain and vicinity, Nevada-California-Investigative results through mid1983. U.S. Geological Survey, Water-Resources Investigations Report 84-4267.

Webb, R. H., and J. L. Betancourt (1990). The spatial and temporal distribution of radiocarbon ages from packrat middens.In Packrat middens: The last 40,000 years of biotic change (J. L. Betancourt, T. R. Van Devender, and P. S. Martin, Eds.), pp. 85-102. University of Arizona Press, Tucson.

Wells, P. V., and R. Berger (1967). Late Pleistocene history of coniferous woodland in the Mojave Desert. Science 155, 1640-1647.

Wells, P.V., and Woodcock, D. (1985). Full-glacial vegetation of Death Valley, California-Juniper woodland opening to Yucca semidesert. Madrono 32, 11-23.

Wigand, P. W. (1990). Vegetation History. In Archaeological and Paleoenvironmental Investigations in the Ash Meadows National Wildlife Refuge Nye County, Nevada, by S. D. Livingston and F. L. Nials, pp. 15-48. Desert Research Institute Technical Report No. 70, Reno, NV.

Winograd, I. J., and G. C. Doty (1980). Paleohydrology of the southern Great Basin with special reference to water table fluctuations beneath the nevada Test Siteduring the late (?) Pleistocene. U. S. Geological Survey Open-File Report 80569. 


\section{APPENDIX I}

The Current Vegetation and Plant Macrofossil Data From The Fortymile Canyon Packrat Midden Sites

Table 1.1: Trees, shrubs, and succulents.

pp. 59-65

Table 1.2: Herbs, forbs, and grasses............................... pp. 66-70

Table 1.3: Other remains, unknowns, and summary data....... pp. 71-73 


\section{TABLE 1.1}

Trees, shrubs, and succulents from the Fortymile Canyon packrat midden sites 


\begin{tabular}{|c|c|c|c|c|c|c|c|c|c|c|c|}
\hline & SITE AND SAMPLE: & & & Fortymile & FMC-7 & FMC-7(1) & FMC.7(3) & FMC-8 & FMC-8A & FMC-9 & FMC9A \\
\hline & ASPECT/ APPRX.14-C AGE: & & & Canyon Wash & $\mathbf{W}$ & 47,240 & $>52,000$ & NE & 18,530 & N to E & 21,830 \\
\hline FAMILY & GENUS AND SPECIES & AFFINITY & FLOWERING & & & & & & & & \\
\hline & & & & & & & & & & & \\
\hline Agavacese & Yucca baccala & & & & & & & & & & \\
\hline Anacardiaceae & Rhus trilobata & & & & & & & & & 1 & \\
\hline \multirow[t]{28}{*}{ Asteraceac } & Ambrosia eriocentra & $\mathrm{DR}$ & & $\bar{x}$ & & & & & & & \\
\hline & Ambrosia cf, acanthicarpa & DR & & & & 1 & & & & & \\
\hline & Artemisia dracunculus & & Aug. - Sept. & $x$ & 3 & & & 3 & & 2 & \\
\hline & Artemisia tridentata & & & & & & & & & 3 & \\
\hline & Artemisia subgen. Tridentatae & & & & & 1 & 3 & & 3 & & 4 \\
\hline & Brickellia califomica & 1 & & & & & & & & & 1 \\
\hline & Brickellia microphylla & & & & 2 & & & 2 & & 1 & \\
\hline & Brickellia oblongifolia & & & $x$ & & & & & & & 2 \\
\hline & Brickellia sp. & & & & & & & & & & \\
\hline & Chrysothamnus albidus-type & 1 & & & & & & & & & \\
\hline & Chrysothamnus nauscosus & 1 & & & & 1 & 3 & & & & \\
\hline & Chrysothamnus paniculatus & DR & & $\boldsymbol{x}$ & & & & & & & \\
\hline & Chrysothamnus of. panryi & 1 & & & & & & & & & \\
\hline & Chrysothamnus teretifolius & & & & 2 & & & 1 & & 1 & \\
\hline & Chrysothamnus viscidiflorus & & & & & 1 & 1 & 1 & 3 & 1 & 4 \\
\hline & Chrysothamnus sp. & & & & & & & & & & \\
\hline & Encelia cf. frutescens & & & & & & & & & & \\
\hline & Encelia virginensis & & & $x$ & & & & & & & \\
\hline & Encelia sp. & & & & & & & & & & \\
\hline & Gutierezia microcephala & & & & & & & 3 & & 2 & \\
\hline & Haplopappus cuneatus & & & & 2 & & & & & 2 & \\
\hline & Haplopappus linearifolius & & & & * & & & 2 & & 1 & \\
\hline & Haplopappus nanus & & & & & 3 & 2 & & & & 1 \\
\hline & Hymenoclea salsola & & & $x$ & & & & 1 & & & \\
\hline & Lepidospartum latisquamum & $1, \mathrm{DR}$ & & & & & & & & & \\
\hline & cf. Stephanomeria sp. & & & & & & & & 1 & & \\
\hline & Tetradymia axillaris & & $\therefore$ & & & & & & & & \\
\hline & Tetradymia canescens-type & 1 & & & & 1 & 2 & & 1 & & 2 \\
\hline \multirow[t]{6}{*}{ Cactaceac } & Echinocactus polycephalus & 1 & & & & & & & & & \\
\hline & Echinocereus engelmannii & & & & 1 & & & 1 & & 1 & \\
\hline & Opuntia basilaris & & & & & & & 1 & & 1 & \\
\hline & Opuntia erinacea & & & & & & & 1 & & & \\
\hline & Opuntia echinocarpa & & & & & & & 1 & & & \\
\hline & Opuntia cf. polyacantha & $!$ & & & & 2 & 3 & & 1 & & 3 \\
\hline
\end{tabular}




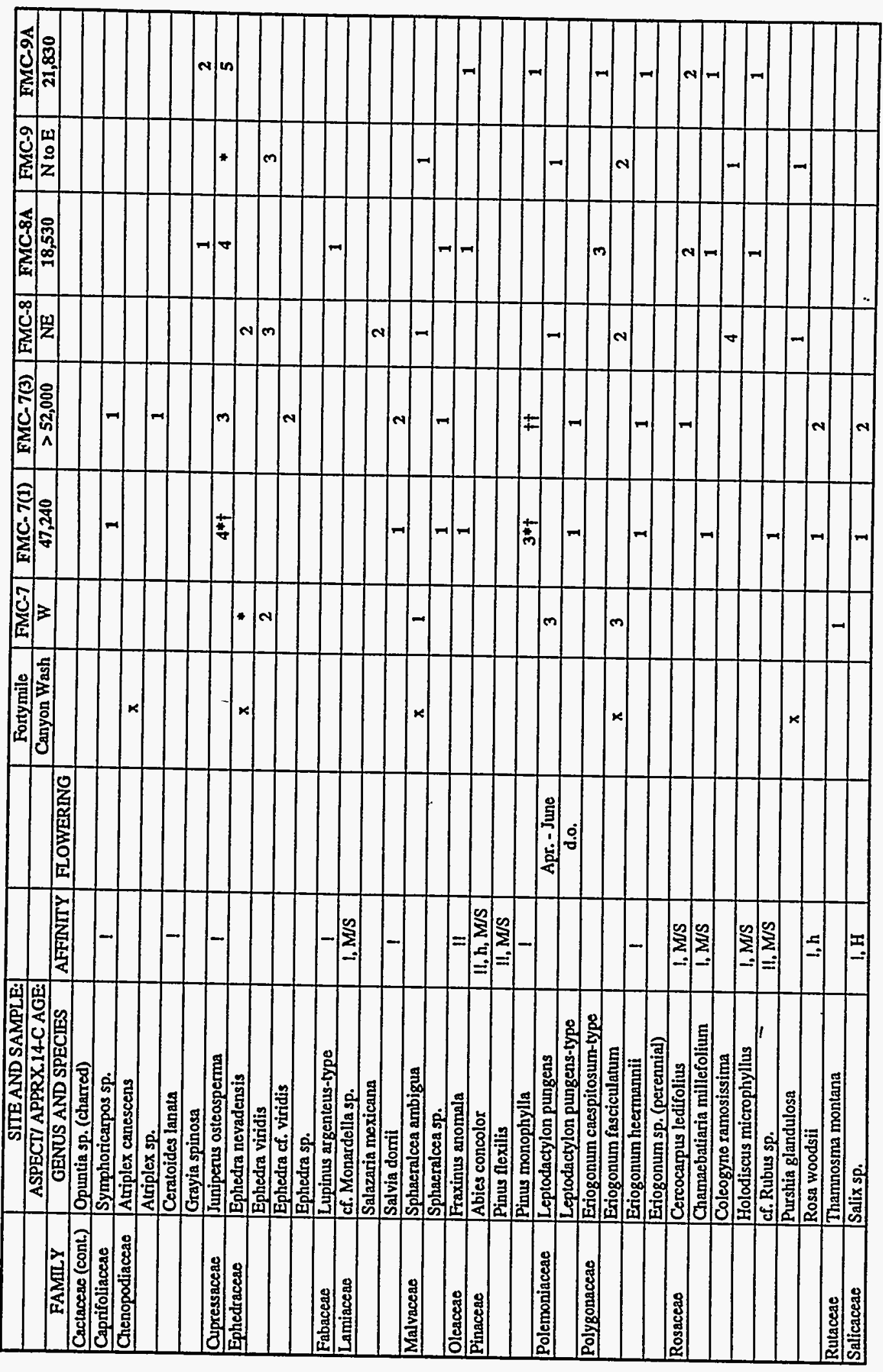




\begin{tabular}{|c|c|c|c|c|c|c|c|c|c|c|c|}
\hline & SITEAND SAMPLE: & & & Fortymile & FMC-7 & FMC-7(1) & FMC-7(3) & FMC-8 & FMC-8A & FMC-9 & FMC-9A \\
\hline & ASPECT/APPRX.14C AGE: & & & Canyon Wash & W & 47,240 & $>52,000$ & $\mathrm{NE}$ & 18,530 & N to E & 21,830 \\
\hline FAMILY & GENUS AND SPECIES & AFFINITY & FLOWERING & & & & & & & & \\
\hline \multirow[t]{2}{*}{ Saxifragaceac } & Ribes velutinum & $!$ & & & & & & & & & \\
\hline & Ribes sp. & 1 & & & & 1 & 2 & & 1 & & \\
\hline \multirow[t]{3}{*}{ Solanaceao } & Lycium andersonii & & & & & & & 1 & & & \\
\hline & Lycium cf. cooperi & & & & & & & & & & \\
\hline & cf. Nicotiana attenuata & $!$ & & & & & & & 1 & & \\
\hline Ulmacese & Cellis reticulata & h & & & & & & & & ***; & \\
\hline \multirow[t]{2}{*}{ Zygophyllaceae } & Larrea divaricala & & & $\mathbf{x}$ & & & & ** & & & \\
\hline & & & & & & & & & & & \\
\hline \multicolumn{2}{|c|}{ Key to occurence symbols: } & & & & \multicolumn{2}{|c|}{ Key to affinity symbols } & & & & & \\
\hline & \multicolumn{3}{|c|}{ * in the vicinity of the siles, but more than 50 m distant } & & \multicolumn{3}{|c|}{ DR-desert-riparian taxon } & & & & \\
\hline & \multicolumn{3}{|c|}{ ** in the vicinity, but more than $100 \mathrm{~m}$ from site } & & \multicolumn{3}{|c|}{ H-obligate hydrophile or phreatophyte } & & & & \\
\hline & \multicolumn{2}{|c|}{ *** ca. $200 \mathrm{~m}$ distant in wash bottom } & & & \multicolumn{4}{|c|}{ h- facultative hydrophile or phreatophyte } & & & \\
\hline & \multicolumn{3}{|c|}{ I nut shell fragments only, not tallied in Nts or $\mathrm{N}$} & & \multicolumn{3}{|c|}{ M/S- montane or subalpine taxon } & & & & \\
\hline & \multicolumn{4}{|c|}{ It one fragment only, potential contaminant, not tallied in Nis or $\mathrm{N}$} & \multicolumn{2}{|c|}{ !- extralocal species } & & & & & \\
\hline & If two species & & & & \multicolumn{2}{|c|}{ 11- extralimital species } & & & & & \\
\hline & * † observed in fecal pellets & & . & & & & & & & & \\
\hline & & & & & & & & & & & \\
\hline
\end{tabular}




\begin{tabular}{|c|c|c|c|c|c|c|c|c|c|c|c|c|}
\hline & \begin{tabular}{r|} 
SITE AND SAMPLE: \\
ASPECT/ APPRX.14-C AGE:
\end{tabular} & & & FMC-10 & FMC-10A & FMC-10C & FMC-11 & FMC11A(1) & FMC-11A(2) & FMC $11 B$ & FMC-12 & FMC-12B \\
\hline & ASPECT/APPRX.14-CAGE: & & & Sto W & 9,470 & 9,390 & $N$ & 15,870 & 16,410 & 12,870 & NE to $S$ & 2,770 \\
\hline FAMIIY & GENUS AND SPECIES & AFFINITY & FLOWERING & & & & & & & & & \\
\hline & & & & & & & & & & & & \\
\hline Agavaceae & Yucca baccata & & & & & & & & & & 1 & \\
\hline Anacardiaceae & Rhus trilobata & & & & & & $\bar{x}$ & & & & & \\
\hline \multirow{28}{*}{ Asteraceae } & Ambrosia eriocentra & DR & & & & & & & & & & \\
\hline & Ambrosia cf. acanthicarpa & $\overline{\mathrm{DR}}$ & & & & & & & & & & \\
\hline & Artemisia dracunculus & & Aug. - Sept. & 2 & 2 & 3 & $x$ & & & & 1 & 1 \\
\hline & Artemisia tridentata & & & & & & $x$ & & & & & \\
\hline & Artemisia subgen. Tridentatae & & & & 1 & & & 4 & 4 & 3 & & \\
\hline & Brickellia californica & $!$ & & & & 1 & & & & & & \\
\hline & Brickellia microphylla & & & & & & & & & & 1 & \\
\hline & Brickellia oblongifolia & & & & & & & 1 & 1 & 2 & & \\
\hline & Brickellia sp. & & & & 1 & & & & & & & \\
\hline & Chrysothamnus albidus-type & 1 & & & & 1 & & & & & & \\
\hline & Chrysothamnus nauscosus & 1 & & & & & & & 1 & 1 & & \\
\hline & Chrysothamnus paniculatus & DR & & & & & & & & & & \\
\hline & Chrysothamnus cf. partyi & 1 & & & & & & & 1 & & & \\
\hline & Chrysothanmus teretifolius & & & .3 & & & & & & & 2 & 3 \\
\hline & Chrysothamnus viscidiflorus & & & & & & & 2 & 2 & 2 & & \\
\hline & Chrysothamnus sp. & & & & & & & & & & & \\
\hline & Encelia cf. frutescens & & & & & 1 & & & & & & \\
\hline & Encelia virginensis & & & & & & & & & & & \\
\hline & Encelia sp. & & & & tt & & & & & & & \\
\hline & Gutierrezia microcephala & & & 2 & & & $x$ & & & & 2 & 2 \\
\hline & Haplopappus cuncatus & & & & & & $x$ & & & & & \\
\hline & Haplopappus linearifolius & & & 1 & 1 & 1 & $x$ & & & & 1 & 2 \\
\hline & Haplopappus nanus & & & & & & & & & & & \\
\hline & Hymenoclea salsola & & & & & & & & & & & \\
\hline & Lepidospartum latisquamum & I.DR & & & 1 & 1 & & & & & & \\
\hline & cf. Stephanomeria sp. & & & & & & & & & & & \\
\hline & Tetradymia axillaris & & & & & & & & & & * & 1 \\
\hline & Tetradymia canescens-type & 1 & & & & & & 1 & 2 & & & \\
\hline \multirow{6}{*}{ Cactaceae } & Echinocactus polycephalus & $!$ & & & & & & & & & & 1 \\
\hline & Echinocereus engelmannii & & & 1 & & & & & & & 2 & \\
\hline & Opuntia basilaris & & & 1 & & & & & & & 1 & 1 \\
\hline & Opuntia crinacea & $\cdot$ & & & & & & & & & & \\
\hline & Opuntia echinocarpa & & & & & & & & & & & \\
\hline & Opuntia cf. polyacantha & 1 & & & 4 & 3 & & 1 & 3 & 3 & & \\
\hline
\end{tabular}




\begin{tabular}{|c|c|c|c|c|c|c|c|c|c|c|c|c|}
\hline & SITE AND SAMPLE & & & FMC-10 & FMC-10A & FMC-10C & FMC-11 & FMC-11A(1) & FMC-11A(2) & FMC11B & FMC-12 & FMC-12B \\
\hline & ASPECT/ APPRX.14CAGE: & & & S to W & 9,470 & 9,390 & \begin{tabular}{|l|}
$\mathrm{N}$ \\
\end{tabular} & 15,870 & 16,410 & 12,870 & NE to S & 2,770 \\
\hline \multirow[t]{2}{*}{ FAMILY } & GENUS AND SPECIES & AFFINITY & FLOWERING & & & & & & & & & \\
\hline & Opuntia sp. (charred) & & & & & & & & & & & 1 \\
\hline Caprifoliaceac & Symphoricarpos sp. & $!$ & & & & & & & & 1 & & \\
\hline \multirow{4}{*}{ Chenopodiaceae } & Atriplex canescens & & & & & & & & & & & 1 \\
\hline & Atriplex sp. & & & & & & & & & & & \\
\hline & Ceratoides lanata & $!$ & & & & & & & & & & 1 \\
\hline & Grayia spinosa & & & 1 & & & & & & & 1 & \\
\hline Cupressaceac & Juniperus osteosperma & $!$ & & & $4 * t$ & 3 & * & 4 & 3 & 3 & & 2 \\
\hline \multirow[t]{4}{*}{ Ephedraceac } & Ephedra nevadensis & & & 2 & & & & & & & 1 & \\
\hline & Ephedra viridis & & & & & & $x$ & & & & 2 & \\
\hline & Ephedra cf. viridis & & & & & & & & & & & 3 \\
\hline & Ephedra sp. & & & & & & & tt & & & & \\
\hline Fabaccac & Lupinus argenteus-type & 1 & & & & & & 2 & 1 & 1 & & \\
\hline \multirow[t]{3}{*}{ Lamiaceac } & cf. Monardella sp. & I. M/S & & & & & & & 1 & 1 & & \\
\hline & Salazaria mexicana & & & & & & & & & & 2 & 1 \\
\hline & Salvia dorrii & 1 & & & & & & 1 & 2 & 1 & & \\
\hline \multirow[t]{2}{*}{ Malvaceae } & Sphaeralcea ambigua & & & & 2 & 1 & & & & 2 & 2 & 1 \\
\hline & Sphaeralcea sp. & & & & & & & & & & & \\
\hline Oleaceae & Fraxinus anomala & 11 & & & & & & 1 & 1 & 2 & & \\
\hline \multirow[t]{3}{*}{ Pinaceace } & Abies concolor & $11, h, M / S$ & & & & & & $t t$ & & & & \\
\hline & Pinus flexilis & $11, \mathrm{M} / \mathrm{S}$ & & & & & & 1 & 1 & & & \\
\hline & Pinus monophylla & 1 & & & tt & 1 & & 1 & $1 * t$ & $t$ & & \\
\hline \multirow[t]{2}{*}{ Polemoniaceae } & Leptodractylon pungens & & Apr. - June & & & & $x$ & & & & 1 & \\
\hline & Leptodactylon pungens-type & & d.o. & & 1 & 1 & & & & 1 & & 1 \\
\hline \multirow[t]{4}{*}{ Polygonaceae } & Eriogonum caespitosum-type & & & & & & & & & & & \\
\hline & Eriogonum fasciculatum & & & 4 & & & $\mathbf{x}$ & & & & 3 & 3 \\
\hline & Eriogonum heermannii & 1 & & & & & & & & & & \\
\hline & Eriogonum sp. (perennial) & & & & 1 & 1 & $x$ & 1 & 2 & & & \\
\hline \multirow[t]{7}{*}{ Rosaceac } & Cercocarpus ledifolius & $1, \mathrm{M} / \mathrm{S}$ & & & & & & 3 & 3 & 3 & & \\
\hline & Chamaebatiaria millefolium & $1, \mathrm{M} / \mathrm{S}$ & & & & & & 1 & 1 & 1 & & \\
\hline & Coleogyne ramosissima & & & & & & & & & & 1 & 1 \\
\hline & Holodiscus microphyllus & $1, \mathrm{M} / \mathrm{S}$ & & & & & & 1 & 1 & 1 & & \\
\hline & cf. Rubus sp. & I!, M/S & & & & & & & & & & \\
\hline & Purshia glandulosa & & & & 4 & 4 & & & & 1 & 1 & 2 \\
\hline & Rosa woodsii & $1, \mathrm{~h}$ & & & & & & & & & & \\
\hline Rutaceac & Thamnosma montana & & & & & & & & & & & \\
\hline Salicacease & Salix sp. & $1 . \mathrm{H}$ & & & & & & & - & & & \\
\hline
\end{tabular}




\begin{tabular}{|c|c|c|c|c|c|c|c|c|c|c|c|c|}
\hline & SITE AND SAMPLE: & & & FMC-10 & FMC-10A & FMC-10C & FMC-11 & FMC-11A(1) & FMC-11A(2) & FMC-11B & FMC-12 & FMC-12B \\
\hline & ASPECT/APPRX.14-C AGE: & & & S tow & 9,470 & 9,390 & $\mathrm{~N}$ & 15,870 & 16,410 & 12,870 & $\mathrm{NE}$ to $S$ & 2,770 \\
\hline FAMILY & GENUS AND SPECIES & AFFINITY & FLOWERING & & & & & & & & & \\
\hline \multirow[t]{2}{*}{ Saxifragaceace } & Ribes velutinum & 1 & & & & & & $\overline{1}$ & & $t+$ & & \\
\hline & Ribes sp. & $T$ & & & & & & & & & & \\
\hline \multirow[t]{3}{*}{ Solanaceas } & Lycium andersonii & & & 2 & & & & & & & & \\
\hline & Lycium cf. cooperi & & & & & & & & & & & 2 \\
\hline & cf. Nicotiana attenuata & 1 & & & & & & & & & & \\
\hline Ulmaceae & Cellis reticulata & $\mathbf{h}$ & & & & & & & & & & \\
\hline \multirow{2}{*}{ Zygophyllaceae } & Larrea divaricata & & & & & & & & & & & \\
\hline & & & & & & & & & & & & \\
\hline \multicolumn{2}{|c|}{ Key to occurence symbols: } & & & & \multicolumn{2}{|c|}{ Key to affinity symbols: } & & & & & & \\
\hline & \multicolumn{3}{|c|}{ * in the vicinity of the sites, but more than $50 \mathrm{~m}$ distant } & & \multicolumn{2}{|c|}{ DR-desert-riparian taxon } & & & & & & \\
\hline & \multirow{2}{*}{\multicolumn{3}{|c|}{ ** in the vicinity, but more than $100 \mathrm{~m}$ from site }} & & \multicolumn{4}{|c|}{ H-obligate hydrophile or phreatophyte } & & & & \\
\hline & & & & & \multicolumn{4}{|c|}{ h- facultative hydrophile or phreatophyte } & & & & \\
\hline & \multicolumn{3}{|c|}{ t nut shell fragments only, not tallied in Nts or $\mathrm{N}$} & & M/S-montane & or subalpine t: & taxon & & & & & \\
\hline & \multicolumn{4}{|c|}{ i† one fragment only, potential contaminant, not tallied in Nts or $N$} & \multicolumn{2}{|c|}{ 1- extralocal species } & & & & & & \\
\hline & \begin{tabular}{|l|l}
$t+t$ two species \\
\end{tabular} & & & & |11- extralimita & species & & & & & & \\
\hline & * tobserved in fecal pellets & & & & & & & & & & & \\
\hline & & & & & & & & & & & & \\
\hline
\end{tabular}




\section{TABLE 1.2}

Herbs, forbs, grasses, and family-level identifications from the Fortymile Canyon packrat midden sites 


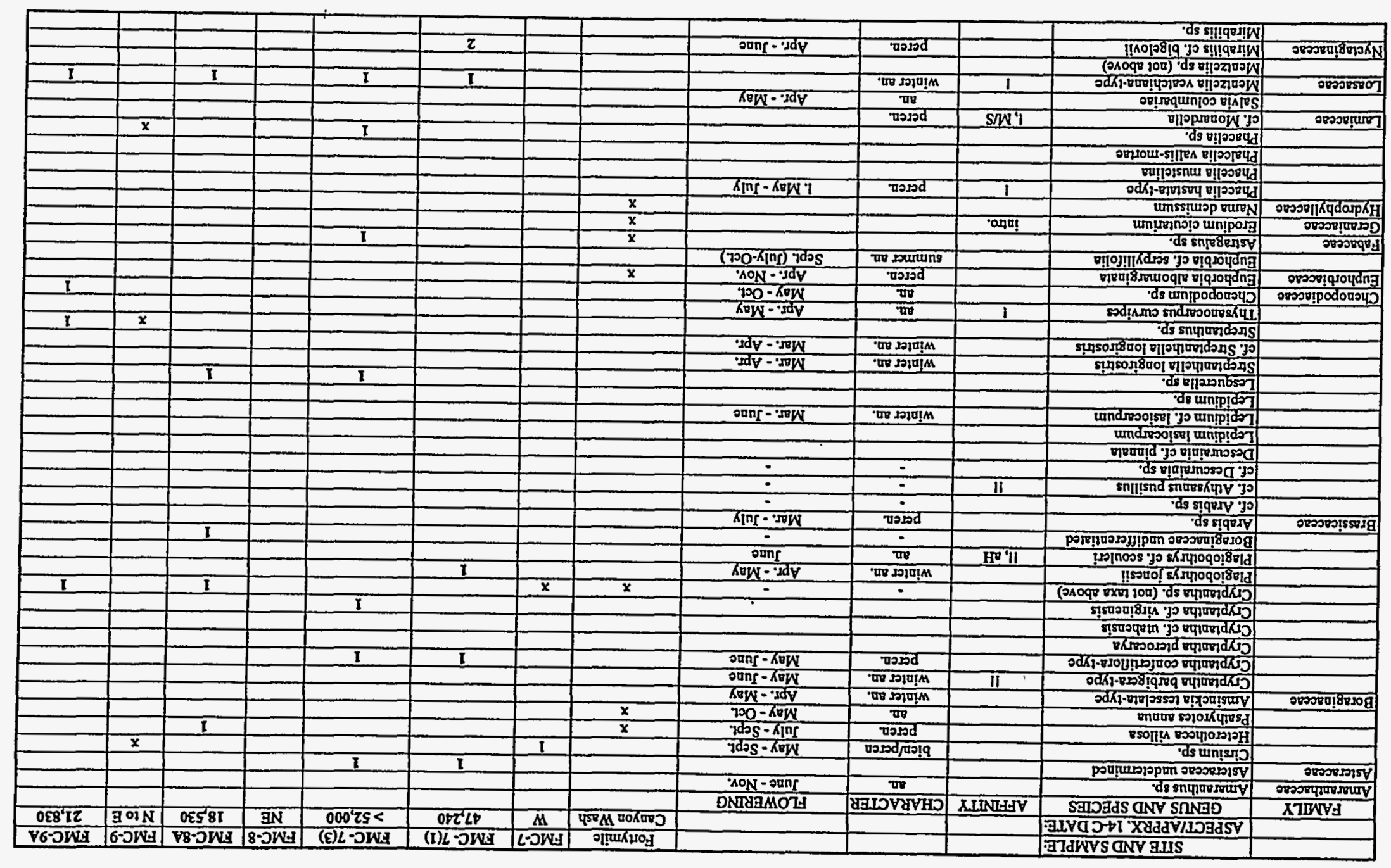




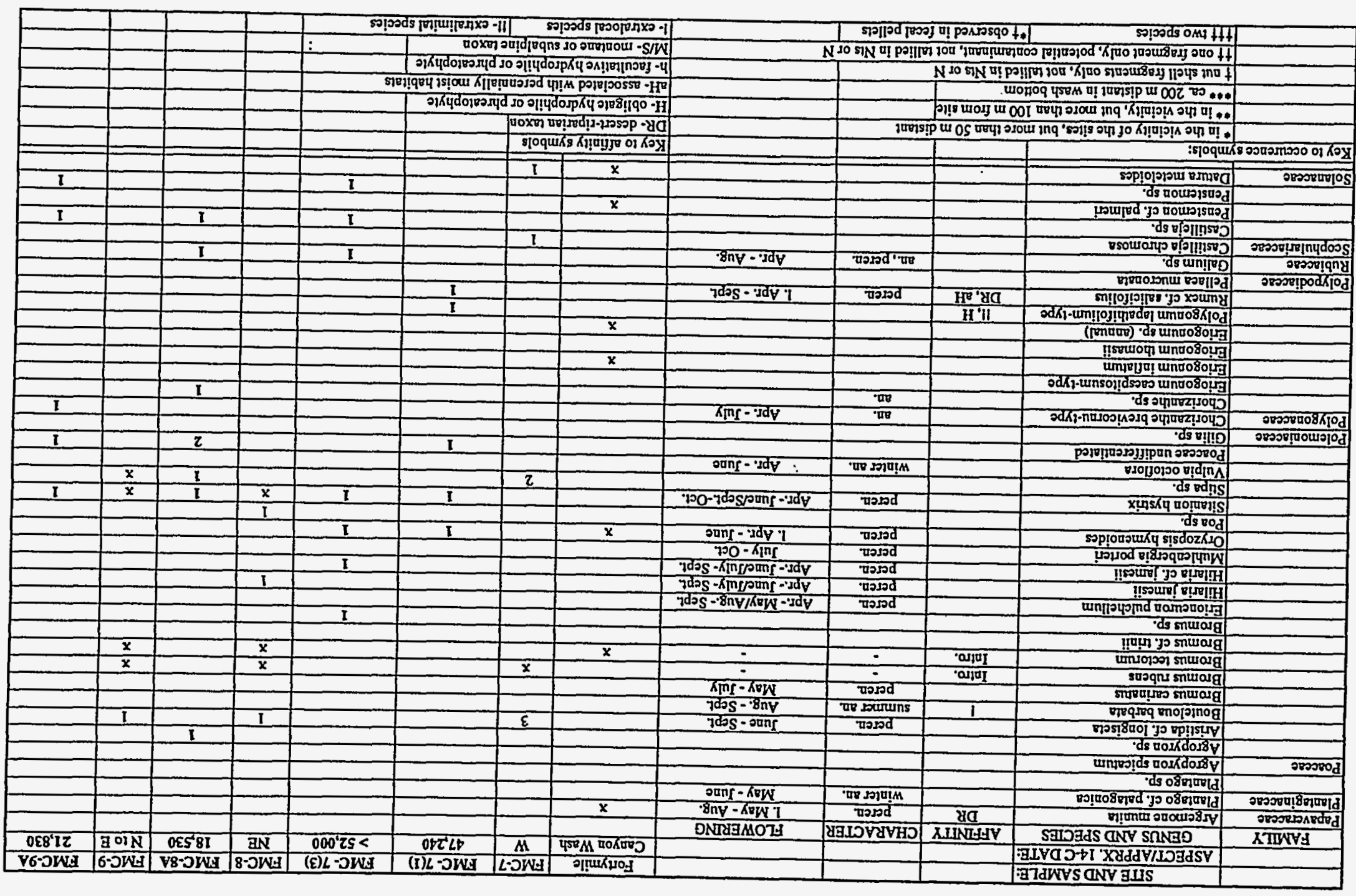




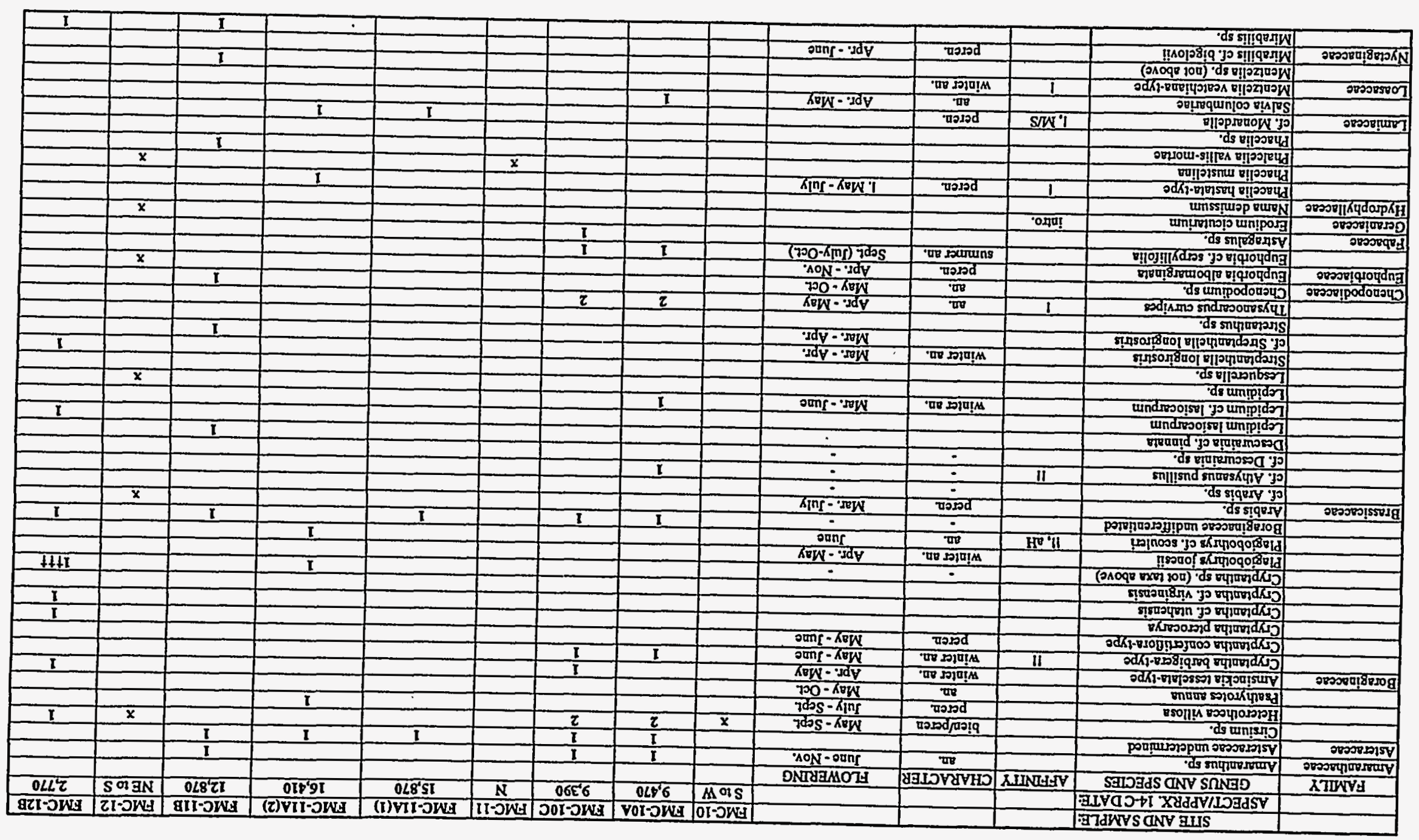




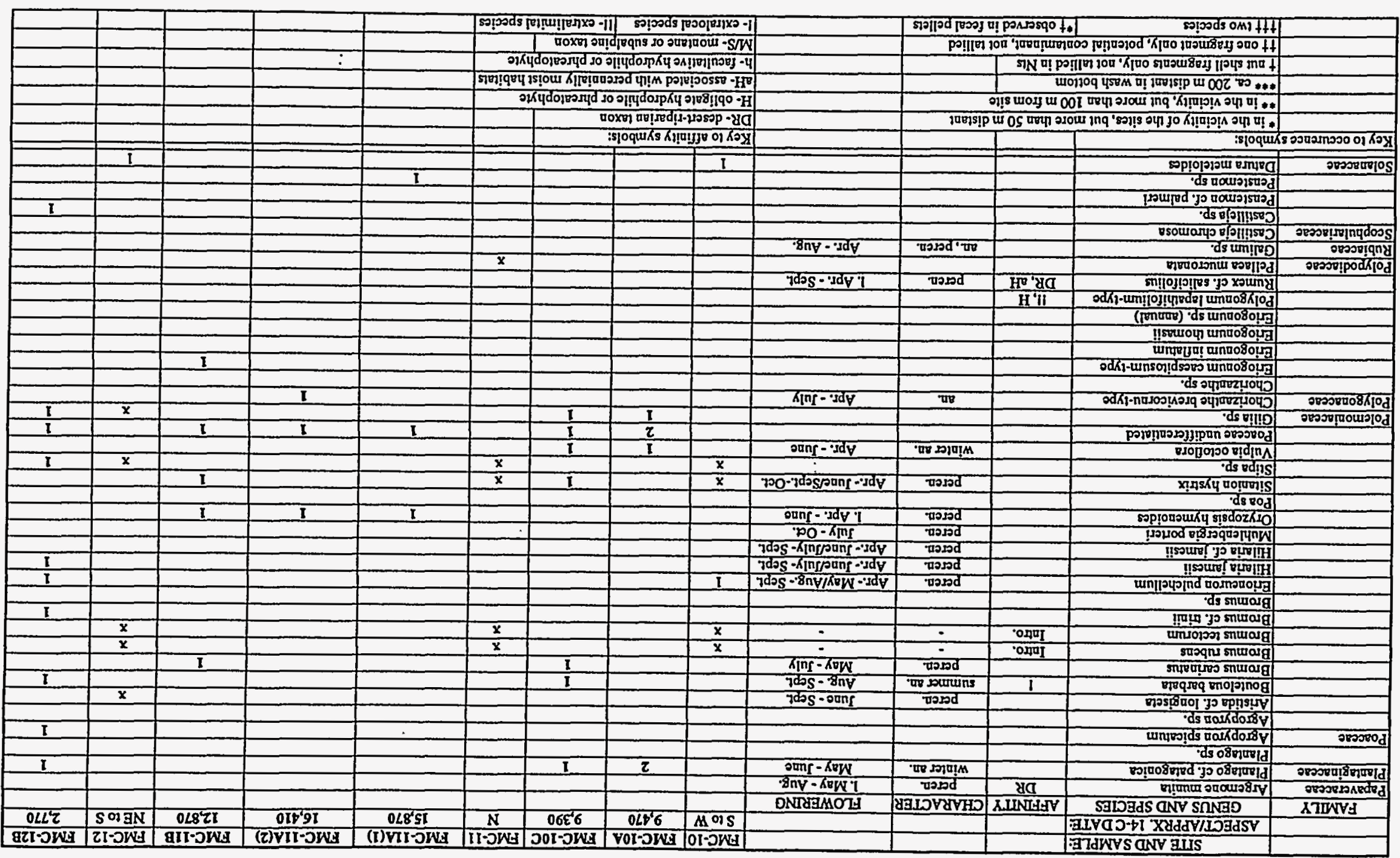


TABLE 1.3

Other remains, unknowns, and summary data from the Fortymile Canyon packrat midden sites 


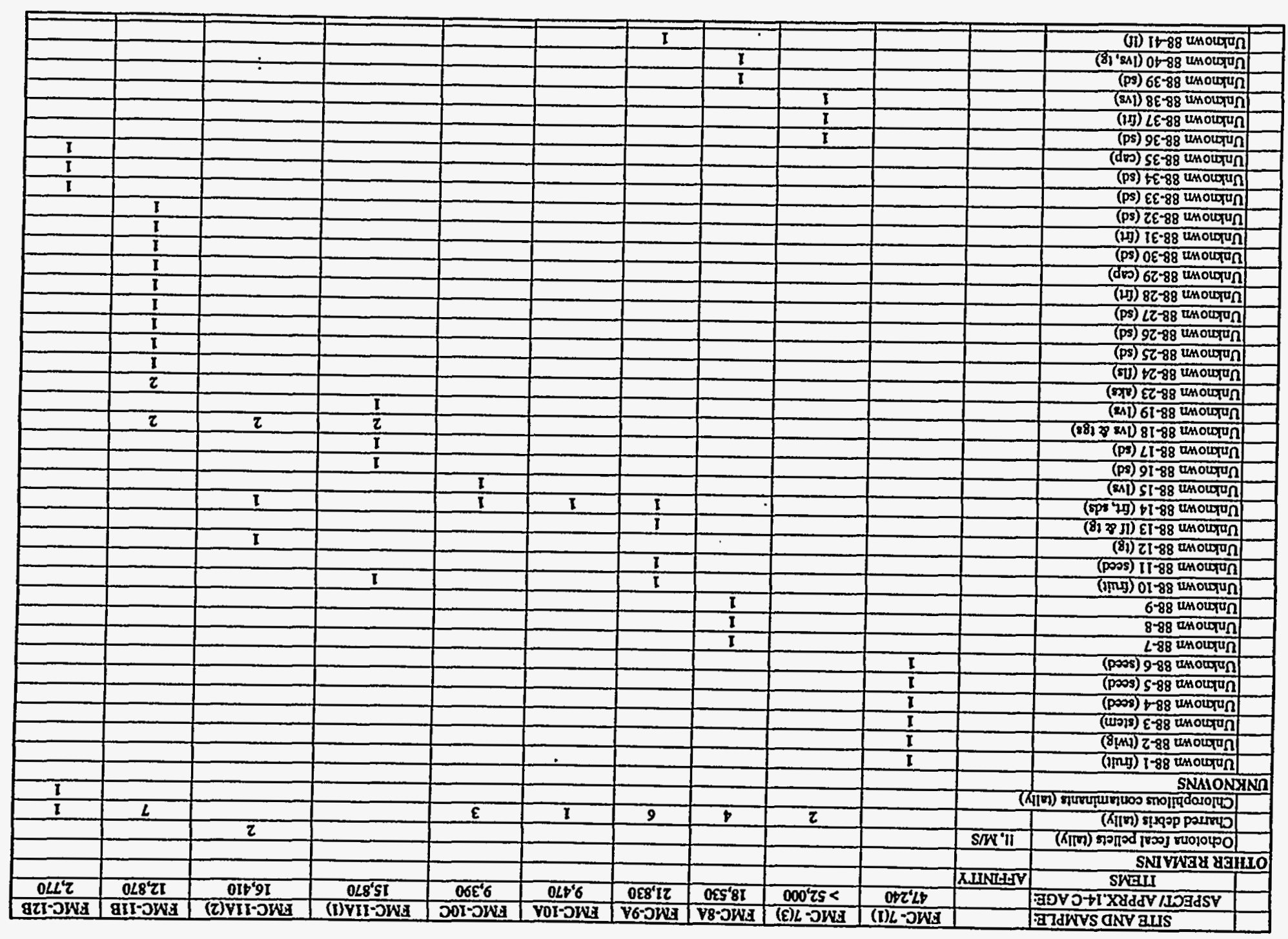




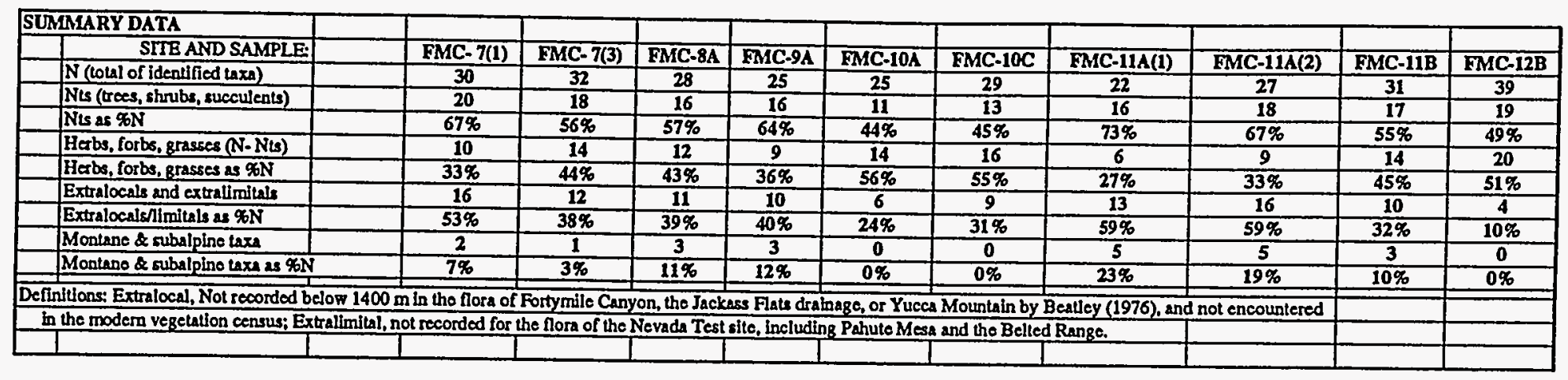




\section{APPENDIX II \\ The Current Vegetation and Plant Macrofossil Data From The Sandy Valley Midden Sites}

Table 2.1: Plant species from the Sandy Valley locality.

pp. $75-77$ 


\begin{tabular}{|c|c|c|c|c|c|c|c|c|c|c|}
\hline & SITE AND SAMPLE: S & & 2 veg. & 2 veg. & $2(1) 1$ & $2(3) 2$ & $2(3) 3$ & 3 veg. & $3(1)$ & $3(2)$ \\
\hline & ASPECT/APPRX.14C A & & NE slope & S slope & 8,790 & 9,250 & 9,400 & - & 8,490 & 9,430 \\
\hline \multicolumn{11}{|c|}{ TREES, SHRUBS, SUBSHRUBS, AND SUCCULENTS } \\
\hline FAMILY & GENUS AND SPECIES & AFFINITY & & & & & & & & \\
\hline \multirow[t]{3}{*}{ Agavaceae } & Yucca brevifolia & & $*$ & $*$ & & & 1 & $*$ & 1 & \\
\hline & Yucca schidigera & & $* *$ & $* *$ & & & & *** & & \\
\hline & Yucca sp. & & & & & 1 & & & & \\
\hline Amaranthaceae & Tidestromia oblongifolia & & & & & & & & 1 & \\
\hline \multirow[t]{12}{*}{ Asteraceae } & Ambrosia dumosa & & $x$ & 3 & $t$ & 1 & & 2 & & \\
\hline & Amphipappus fremontii & & $x$ & 1 & & & & & & \\
\hline & Brickellia arguta & & $x$ & & & & & 2 & & \\
\hline & B. microphylla & & 1 & & & & & & & \\
\hline & Brickellia sp. & & & & & & 2 & & & \\
\hline & Chrysothamnus nauseosus & 1 & & & & 1 & 3 & & & 1 \\
\hline & Encelia farinosa & & $x$ & & & & & & & \\
\hline & Encelia sp. & & & & 1 & 1 & & & 1 & 1 \\
\hline & Gutierrezia microcephala & & $x$ & & & & 1 & 3 & & 2 \\
\hline & Peucephyllum schottii & & $x$ & & & & & & & \\
\hline & Pleurocoronis pluriseta & & & & & & & 1 & & \\
\hline & Stephanomeria sp. & & & & & & & 1 & & \\
\hline \multirow[t]{2}{*}{ Brassicaceae } & Lepidium cf. fremontii & 1 & & & & 2 & 1 & & & \\
\hline & Lepidium montanum-type & & & & 1 & 1 & & & 3 & 2 \\
\hline \multirow[t]{4}{*}{ Cactaceae } & Coryphantha vivipara & & $x$ & & & & & & & \\
\hline & Echinocactus polycephalus & & & 1 & & 1 & 1 & 1 & 1 & \\
\hline & Mammilaria microcarpa & & & & & & & & 1 & \\
\hline & Opuntia sp. & 1 & & & 1 & 1 & 1 & & 1 & 1 \\
\hline \multirow[t]{2}{*}{ Caprifoliaceae } & Symphoricarpos cf. longiflorus & 1 & & & & 1 & & & & 3 \\
\hline & Symphoricarpos sp. & $!$ & & & 1 & & & & & \\
\hline
\end{tabular}




\begin{tabular}{|c|c|c|c|c|c|c|c|c|c|c|}
\hline & SITE AND SAMPLE: SaV-I & & 2 veg. & 2 veg. & $2(1) 1$ & $2(3) 2$ & $2(3) 3$ & 3 veg. & $3(1)$ & $3(2)$ \\
\hline & ASPECT/APPRX. 14-C AGE & AFFINITY & NE slope & S slope & 8,790 & 9,250 & 9,400 & -1 & 8,490 & 9,430 \\
\hline \multirow[t]{6}{*}{ Chenopodiaceae } & Atriplex canescens & 1 & & & & & 1 & & & \\
\hline & Atriplex hymeneletra & & ** & ** & & & & ** & & \\
\hline & Atriplex confertifolia & & & 1 & & & & & & \\
\hline & Atriplex confertifolia-type & & & & 1 & & & & & 4 \\
\hline & Atriplex sp. & & & & & 1 & & & & \\
\hline & Ceratoides lanata & 1 & & & & 1 & & & & 1 \\
\hline \multirow[t]{4}{*}{ Ephedraceae } & Ephedra funerea & & & & & & & 2 & & \\
\hline & Ephedra nevadensis-type & & & & & 1 & & & & 2 \\
\hline & E. torreyana-type & 1 & & & 1 & & & & & \\
\hline & Ephedra sp. & & & & 3 & 3 & 2 & & 1 & \\
\hline Fabaceae & Prosopis juliflora & $1, \mathrm{H}$ & $*$ & * & & & & $*$ & 1 & \\
\hline Krameriaceae & Krameria parvifolia & & & 2 & & $t$ & & 1 & & \\
\hline \multirow[t]{2}{*}{ Lamiaceae } & Salazaria mexicana & & ** & ** & & & & $* *$ & & \\
\hline & Salvia dorrii & $\dot{5}$ & & & & 1 & & & & \\
\hline Loasaceae & Eucnide urens & & $\underline{x}$ & & & & & & 1 & 1 \\
\hline Polygonaceae & Eriogonum heermannii & & $x$ & & & & 1 & 1 & & \\
\hline Rosaceae & Coleogyne ramosissima & 1 & & & & $t$ & 1 & & & \\
\hline Rutaceae & Thamnosma montana & & $x$ & 1 & 2 & 1 & 1 & 1 & 1 & 1 \\
\hline \multirow[t]{4}{*}{ Solanaceae } & Lycium andersonii & & $x$ & 2 & & & & 2 & & \\
\hline & Lycium pallidum & & & & & & & 1 & & \\
\hline & Lycium sp. & & & & 2 & 3 & 2 & & 3 & 3 \\
\hline & Nicotiana trigonophylla & & $\underline{x}$ & & 1 & 2 & & 2 & 2 & 2 \\
\hline Ulmaceae & Celtis reticulata & II, H & & & & & $t$ & & & \\
\hline Zygophyllacese & Larrea divaricata & & $x$ & 2 & & \pm & & 1 & & \\
\hline \multicolumn{11}{|c|}{ HERBS, FORBS, AND GRASSES } \\
\hline Asteraceae & Cirsium sp. & & & & & & & & 1 & \\
\hline \multirow[t]{4}{*}{ Boraginaceae } & Amsinckia sp. & & & & 1 & 1 & 1 & & & 1 \\
\hline & Cryptantha pterocarya & & & & & 1 & & & & \\
\hline & Cryptantha racemosa & & $\underline{x}$ & & & & & & & \\
\hline & Cryptantha sp. & & & & & & & $x$ & & \\
\hline Caryophyllaceae & Scopulophila rixfordii & & $x$ & & 5 & 4 & 4 & & & \\
\hline
\end{tabular}




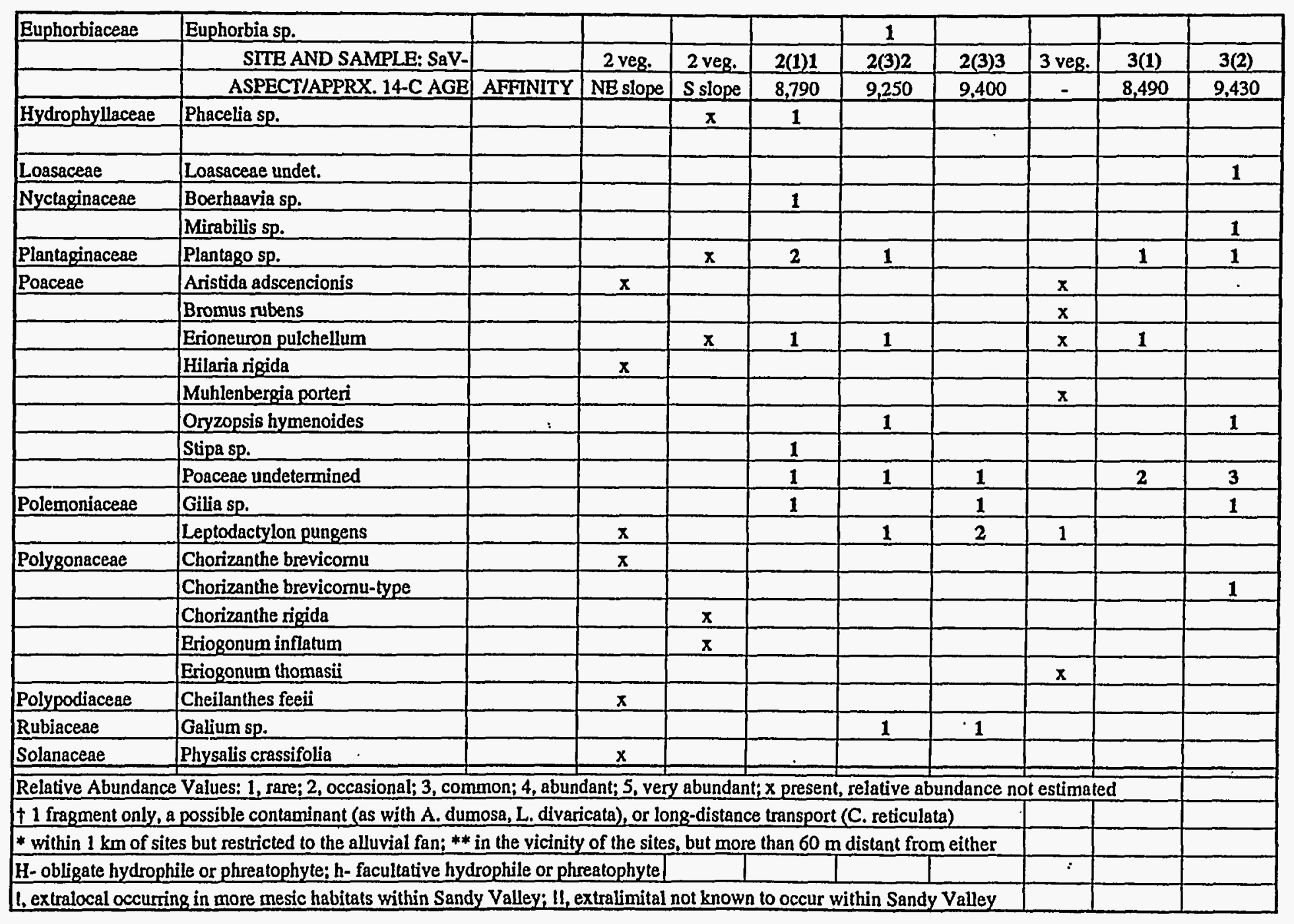




\section{APPENDIX III}

\section{The Current Vegetation and Plant Macrofossil Data}

From The Double Canyon Midden Sites

Table 3.1: Plant species from the Double Canyon locality......... pp. $79-80$ 


\begin{tabular}{|c|c|c|c|c|c|}
\hline & Site and sample no:: & & Modem & $\operatorname{DC}-1(1)$ & DC- $4(2)$ \\
\hline & Approximate14-C age & & veg. & 12,060 & 10,400 \\
\hline \multicolumn{6}{|c|}{$\begin{array}{l}\text { TREES, SHRUBS, AND SUCCULENTS } \\
\text { FAMIIY }\end{array}$} \\
\hline FAMILY & GENUS AND SPECIES & AFFINITY & & & \\
\hline \multirow[t]{2}{*}{ Agavaceae } & Yucca schidigera & & 1 & & \\
\hline & Yucca brevifolia & $!$ & & & 2 \\
\hline \multirow[t]{13}{*}{ Asteraceae } & Ambrosia dumosa & & 2 & & \\
\hline & Ambrosia eriocentra & $\mathrm{DR}$ & $*$ & & \\
\hline & Brickellia arguta & & 2 & & \\
\hline & Brickellia longifolia & & $* *$ & & \\
\hline & Chrysothamnus nauseosus & 1 & & 1 & \\
\hline & Chrysothamnus paniculatus & DR & $*$ & & \\
\hline & Encelia virginensis & & 1 & & . \\
\hline & Gutierrezia microcephala & & 1 & 1 & 1 \\
\hline & Hymenoclea salsola & & * & & \\
\hline & Peucephyllum schottii & & 1 & & \\
\hline & Pleurocoronis pluriseta & & 1 & & \\
\hline & Stephanomeria pauciflora & & ** & & \\
\hline & Xylorhiza tortifolia & & 1 & & \\
\hline Bignoniacese & Chilopsis linearis & h & $*$ & & \\
\hline \multirow[t]{2}{*}{ Brassicaceae } & Lepidium montanum & & 2 & & \\
\hline & Lepidium montanum-type & & & & 1 \\
\hline \multirow[t]{5}{*}{ Cactaceae } & Echinocactus polycephalus & & 1 & & \\
\hline & Echinocereus engelmannii & & 1 & & \\
\hline & Ferocactus acanthodes & & 1 & & \\
\hline & Opuntia erinacea & & 1 & 1 & $\overline{2}$ \\
\hline & Opuntia whipplei & $!$ & & 3 & \\
\hline Caprifoliaceae & Symphoricarpos cf. longiflorus & 1 & & 2 & 1 \\
\hline \multirow{2}{*}{ Chenopodiaceae } & Atriplex canescens & & * & & \\
\hline & Atriplex confertifolia & 1 & & 1 & \\
\hline Cupressaceae & Juniperus osteosperma & $!$ & & 5 & 1 \\
\hline \multirow[t]{3}{*}{ Ephedraceac } & Ephedra nevadensis & & \# & & \\
\hline & Ephedra nevadensis-type & & & & 1 \\
\hline & Ephedra torreyana & & 1 & & \\
\hline \multirow[t]{4}{*}{ Fabaceae } & Acacia greggii & h & * & & \\
\hline & Astragalus sp. & & & 1 & \\
\hline & Prosopis juliflora & $\overline{\mathrm{H}}$ & 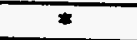 & & \\
\hline & Psorothamnus cf. fremontii & $!$ & & & 1 \\
\hline \multirow[t]{2}{*}{ Lamiaceae } & Salazaria mexicana & & & & \\
\hline & Salvia domii & $!$ & & 1 & 2 \\
\hline Krameriaceae & Krameria parvifolia & & 1 & & \\
\hline Loasaceae & Eucnide urens & & 1 & & \\
\hline Loganiaceae & Buddleja utahensis & & *** & & \\
\hline \multirow{2}{*}{ Malvaceae } & Sphaeralcea ambigua & & 3 & & \\
\hline & Sphaeralcea sp. & & & & 1 \\
\hline Oleaceae & Fraxinus anomala & II & & 1 & \\
\hline Polygonaceae & Eriogonum heermannii & & *** & & \\
\hline \multirow[t]{4}{*}{ Rosaceae } & Coleogyne ramosissima & 1 & & & 3 \\
\hline & Cowania mexicana & 1 & & & 4 \\
\hline & Fallugia paradoxa & 1 & & & 1 \\
\hline & Prunus fasciculata & & 1 & 1 & 2 \\
\hline Rutaceae & Themnosma montana & & 1 & & \\
\hline Saxifragaceac & Ribes cf. velutinum & 11 & & 1 & \\
\hline \multirow[t]{3}{*}{ Solanaceae } & Lycium andersonii & & 2 & & \\
\hline & Lycium pallidum & & 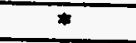 & & \\
\hline & Nicotiana trigonophylla & & 1 & & \\
\hline Zygophyllaceae & Larrea divaricata & & 3 & & \\
\hline
\end{tabular}




\begin{tabular}{|c|c|c|c|c|c|}
\hline & Site and sample no.: & & $\mathrm{DC}-1$ & DC-1(1) & DC. $4(2)$ \\
\hline & Approximate14-C age & & & 12,060 & 10,400 \\
\hline \multicolumn{6}{|c|}{ HERBS, FORBS, AND GRASSES } \\
\hline FAMILY & GENUS AND SPECIES & AFFINITY & & & \\
\hline Asteraceae & Cirsium sp. & 1 & & & 1 \\
\hline \multirow[t]{3}{*}{ Boraginaceae } & Amsinckia sp. & & $\pi$ & & \\
\hline & Cryptantha pterocarya & & $x$ & 1 & \\
\hline & Cryptantha sp. & & $\bar{x}$ & & \\
\hline \multirow[t]{2}{*}{ Brassicaceae } & Arabis sp. & & $\bar{x}$ & & \\
\hline & Descurainia pinnata & & $x$ & & \\
\hline Caryophyllaceae & Scopulophila rixfordii & & ** & 2 & 3 \\
\hline Euphorbiaceae & Euphorbia sp. & & & & 1 \\
\hline \multirow[t]{2}{*}{ Hydrophyllaceae } & Phacelia fremontii & & $x$ & & \\
\hline & Phacelia glechomaefolia & & $\bar{x}$ & & \\
\hline Liliaceae & Dichlostemma pulchellum & & $x$ & & \\
\hline Plantaginaceae & Plantago sp. & & $x$ & & \\
\hline \multirow[t]{7}{*}{ Poaceae } & Aristida adscencionis & & $* *$ & & \\
\hline & Bromus rubens & & $x$ & & \\
\hline & Erioneuron pulchellum & & 1 & & \\
\hline & Hilaria rigida & & 2 & & \\
\hline & Schismus arabicus & & $x$ & & \\
\hline & Stipa arida & & 1 & & \\
\hline & Poaceae undetermined & & - & 1 & 1 \\
\hline \multirow[t]{2}{*}{ Polemoniaceae } & Gilia sp. & & $x$ & & \\
\hline & Leptodactylon pungens & & $* *$ & & \\
\hline \multirow[t]{4}{*}{ Polygonaceae } & Chorizanthe rigida & & $\bar{x}$ & & \\
\hline & Eriogonum fasciculatum & & 2 & & \\
\hline & Eriogonum inflatum & & $x$ & & \\
\hline & Rumex salicilifolius & arH & $*$ & & \\
\hline Polypodiacear & Cheilanthes feeii & & $x$ & & \\
\hline Plantaginaceae & Plantago sp. & & $x$ & & \\
\hline \multirow[t]{2}{*}{ Ranunculaceae } & Anemone tuberosa & & $x$ & & \\
\hline & Delphineum parishii & & $\bar{x}$ & & \\
\hline Rubiaceae & Galium stellatum & & 1 & & \\
\hline Viscacere & Phoradendron californicum & $\mathbf{b}$ & $*$ & & \\
\hline \multicolumn{6}{|c|}{ Relative Abundance Values: 1 , rare; 2 , occasional; 3 , common; 4 , abundant; 5 , very abundant; $x$ present } \\
\hline \multicolumn{6}{|c|}{$\begin{array}{l}\text { * restricted to Pahranagat Wash; }{ }^{* *} \text { in the immediate vicinity, but more than } 30 \mathrm{~m} \text { distant from the sites } \\
\text { aH, associated with riparian habitats; DR, desert riparian species; H- obligate hydrophile or phreatophyte; }\end{array}$} \\
\hline \multicolumn{6}{|c|}{\begin{tabular}{|l|l|l|} 
h- facultative hydrophile or phreatophyte & & \\
\end{tabular}} \\
\hline \multirow{2}{*}{\multicolumn{6}{|c|}{$\begin{array}{l}\text { 1, extralocal likely occurring at higher elevations in the Arrow Canyon Range today } \\
\text { II, a likely extralimital that probably does not occur in the Amow Canyon Range tod: }\end{array}$}} \\
\hline & & & & & \\
\hline
\end{tabular}

